U

$\boldsymbol{\infty}$

\title{
población y desarrollo
}

ndigenous peoples and urban settlements: spatial distribution, internal migration and living conditions

Fabiana Del Popolo

Ana María Oyarce

Bruno Ribotta

Jorge Rodríguez

Latin American and Caribbean

Demographic Centre (CELADE)

Population Division 
This number contains three documents prepared by Fabiana Del Popolo, Ana María Oyarce, Bruno Ribotta and Jorge Rodriguez, who are experts and consultants at the Latin American and Caribbean Demographic Centre (CELADE). These studies have been produced for the International Expert Group Meeting on Urban Indigenous Peoples and Migration (Santiago de Chile, 27-29 March 2007), organized by United Nations Human Settlements Programme (UN-HABITAT), the Office of the High Commissioner for Human Rights (OHCHR), the Secretariat of the United Nations Permanent Forum on Indigenous Issues (UNPFII), CELADE-ECLAC, and the International Organization for Migration (IOM). The preparation of the papers also had the support of the United Nations Population Fund (UNFPA) and the Inter-America Development Bank (IDB)-CELADE project "Migration and Development: the case of Latin America".

The views expressed in this document, which has been reproduced without formal editing, are those of the authors and do not necessarily reflect the views of the Organization.

\author{
United Nations Publication \\ ISSN printed version 1680-8991 \\ ISSN online version 1680-9009 \\ ISBN: 978-92-1-121658-5 \\ LC/L.2799-P \\ Sales No: E.07.II.G.132 \\ Copyright $\odot$ United Nations, July 2007. All rights reserved \\ Printed in United Nations, Santiago, Chile
}

Applications for the right to reproduce this work are welcomed and should be sent to the Secretary of the Publications Board, United Nations Headquarters, New York, N. Y. 10017, U.S.A. Member Status and their governmental institutions may reproduced this work without prior authorization, but are requested to mention the source and inform the United Nations of such reproduction. 


\section{Index}

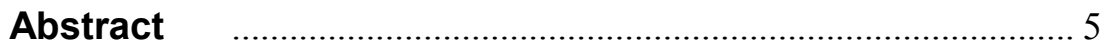

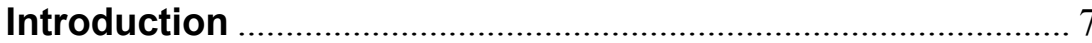

I. Spatial distribution of indigenous peoples in Latin

America: a census-based interpretation ......................... 11

1. Background and objectives ................................................ 11

2. Conceptual and methodological considerations ................. 12

2.1 Anchoring the difference: the relationship of indigenous peoples to territory

2.2 Political and administrative units: the limits of information

3. Census results .............................................................. 15

3.1 Rural and urban indigenous groups: two facets of the same people

3.2 Focusing on regions of indigenous settlement: distribution by major administrative division.

3.3 Spatial distribution on a smaller territorial scale.

3.4 Urban indigenous population: new living spaces and inequality reproduced.......................................... 23

4. Closing reflections.......................................................... 28

II. Internal migration of indigenous peoples:

systematizing and analysing relevant census information in order to update perspectives, increase knowledge and improve interventions

1. Purpose of study and object of analysis.............................. 31

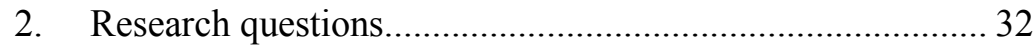


3. Migratory intensity, patterns and profiles among indigenous peoples, and

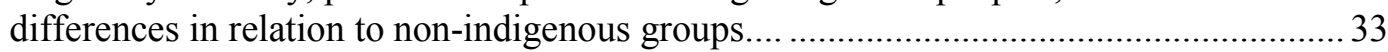

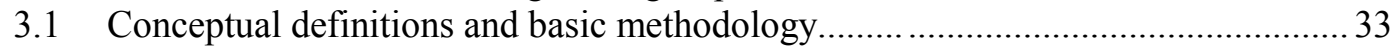

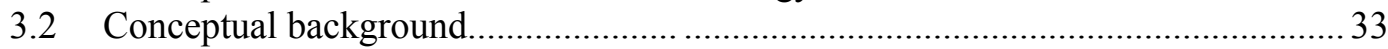

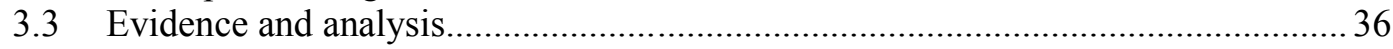

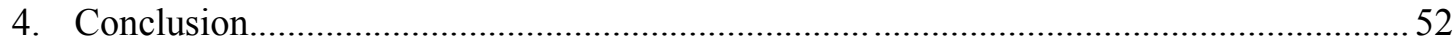

III. Living conditions of urban indigenous people in the context of the

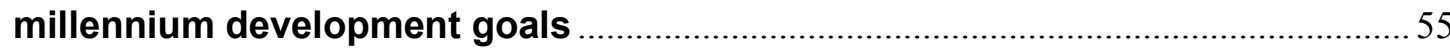

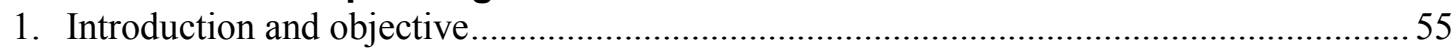

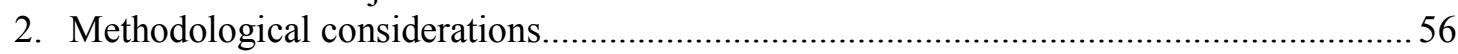

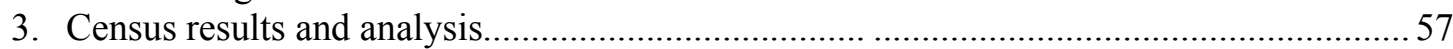

3.1 Formal education: Is access improving for indigenous persons in rural areas? Do ethnic and gender gaps still exist in cities? Are native languages being maintained?................................................................................................. 57

3.2 Health in childhood: Is the risk of early death lower in cities? Are there still

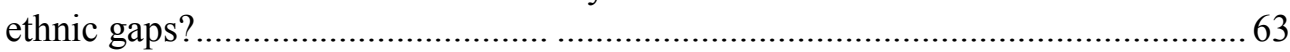

3.3 Sustainability of the environment: Is the access of urban indigenous people to basic services improving? Are inequities being reduced?..................................67 67

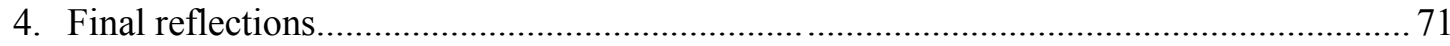

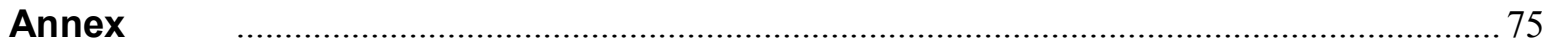

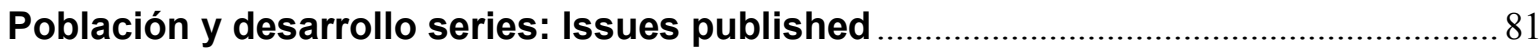




\section{Abstract}

By processing Census micro data from 10 countries in the region, we answer several questions that can be categorized under the following three main topics: a) spatial distribution trends of indigenous peoples in Latin America, with emphasis on the urbanization process and the spatial pattern of this population within selected cities; b) internal migration of indigenous peoples, with emphasis on rural to urban flows; and c) living conditions of indigenous peoples, with emphasis on inequalities between urban and rural areas.

Our results confirm both an increasing proportion of the indigenous population residing in urban areas and the propensity to settle in urban centres close to their home territory rather than in the big metropolises. Within cities, high concentrations of indigenous people are typically found in geographical areas that have higher than average poverty levels. Regarding the second topic we find indigenous people have strong incentives to migrate to cities, and the fact that they have been making that move in recent years will only serve to strengthen the networks that feed back into more migration. The downside is that indigenous peoples have lower socio-economic status in cities, the cost of living is higher than in their places of origin, and sometimes migrants suffer marginalization from their origin communities. Finally, our results on conventional indicators on education, health and access to basic services indicate that living conditions of urban indigenous people are more favourable than those of indigenous people in rural areas. Nevertheless, ethnic inequities in cities persist and in some cases are intensified, reflecting the discrimination and social exclusion that affect indigenous people who live in cities. 



\section{Introduction}

\section{General background}

Recognition of the cultural diversity of the world's peoples is one of the most significant social developments of the beginning of the twenty-first century. In Latin America, this diversity has a distinctive tone, as its indigenous peoples are the same ones who inhabited the continent prior to the arrival of the European conquistadors and who had their own extensive variety of forms of political and social organization and cultural features. Ever since the first contact was made, discriminatory practices based on an ideology of Western cultural superiority have defined the subordinate position of indigenous peoples in Latin American social structures. This process was consolidated in the nineteenth century as nation-states were formed which, pursuing an ideal of ethnic and cultural homogeneity, continued their assimilationist policies until the middle of the last century.

Over the last few decades, however, most countries have recognized their multi-ethnic and multicultural nature, as a result of the persistent struggles of indigenous peoples and a more favourable socio-political context (ECLAC, 2006a). Significant (yet insufficient) progress has been made on legislative and legal issues. Indigenous peoples' individual and collective rights have been recognized, and there is now a minimum standard of rights which includes the following categories: the right to non-discrimination; the right to cultural integrity; the right to own, use, control and have access to land, territories and natural resources; the right to development and social well-being; the right to political participation, and to free, prior and informed consent. 
Another significant phenomenon in the region has been a growing process of urbanization and rural-to-urban migration, which has also had an impact on indigenous peoples, albeit with significant differences in relation to non-indigenous persons in terms of relative numbers, causes, itineraries, meanings and consequences. ${ }^{1}$ The 2000 round of censuses shows that around $40 \%$ of the region's indigenous population lives in urban areas, compared with $80 \%$ for the non-indigenous population. Although indigenous people still live mainly in rural areas, the ethnic and cultural diversity of cities is such that public policy-makers must take into account the perspective of indigenous peoples' rights (both individual and collective rights) in urban areas as well. ${ }^{2}$

Urban indigenous population is not a homogenous group and the diversity of their circumstances is reflected in at least three dimensions: (1) origin; (2) type of interaction between different social groups, according to socioeconomic position and status; and (3) the different forms of inter-ethnic contact associated with the specific sociocultural patterns of each people and their urban context. In relation to the first dimension, there are at least three groups: indigenous groups who resided in territories where cities were founded and who are still present in those areas; descendants of previous generations of migrants, that is, urban indigenous people born in the cities; and urban indigenous people who are actual immigrants.

The different situations described may be related to the particular living conditions of urban indigenous groups, but there has been little research on this issue. Local studies show that links with communities of origin are maintained and even strengthened (through remittances, ceremonies and organizations), although little is known about the dynamics of this process among different groups. These links seem to play a significant role in the integration process for indigenous migrants in cities, while they may also have an effect of limiting and reproducing marginality when social circuits are very closed (León, 2003). There have also been constant movements between urban and rural areas.

\section{Specific context}

In view of the new sociopolitical and demographic realities of the indigenous populations, increasing concerns have been raised within the international, regional and national scope of the migration and territorial mobility procedures as well as for the life conditions of the indigenous persons who live in the cities.

That's how, in year 2005, the United Nations Human Settlements Programme (UNHABITAT) and the Office of the High Commissioner for Human Rights (OHCHR) launched a research iniciative, titled "Indigenous peoples' right to adequate housing: A global overview". During 2006, the International Organisation for Migration (IOM) and the Secretariat of the United Nations Permanent Forum on Indigenous Issues (UNPFII), held an Expert Seminar on "Indigenous peoples and migration: Challenges and opportunities" (Geneva from 6-7 April). Moreover, the UNPFII recommended, in its fourth session, that an Expert Group Meeting be organised. At its fifth session, UNPFII reiterated its recommendation and to expand the scope of this endeavour beyond the field of housing, to cover urban issues comprehensively under the general title of "Urban indigenous peoples and migration". It is important to note in this relation that the Expert Seminar on "Indigenous peoples and migration: Challenges and opportunities" stressed the need for addressing the nexus between indigenous peoples and migration within the following three main areas: (i) state responsibility; (ii) information sharing; (iii) and the role of the international community. The recommendations included the need to recognise the broad -positive and negative- impact of

${ }^{1}$ For example, a lower rate of indigenous migration is partly due to indigenous peoples' indissoluble links with the land.

${ }^{2}$ A number of studies in Mexico, Guatemala and Chile reflect not only the urbanization of indigenous peoples but also the ethnicization of the cities. 
indigenous peoples' migration on society, and the urgency of strengthening the implementation of existing laws to protect indigenous migrants. ${ }^{3}$

Therefore, UN-HABITAT and UNPFII, invited OHCHR and Latin America and the Caribbean Demographic Centre (CELADE) - ECLAC, in cooperation with International Organisation for Migration (IOM), to organize the "Expert Group meeting on Urban Indigenous Peoples and Migration", with support from the Government of Canada and other interested Governments. This meeting was held 27-29 March 2007, ECLAC, Santiago, Chile, and it sought to draw on the expertise, capacity and resources of relevant United Nations organisations and agencies; national and local governments; organisations of indigenous peoples, indigenous youth; representatives of NGOs active within the field of indigenous peoples, urbanisation and urban development; and specialists and researchers within relevant fields. The participants invited were selected according to gender and geographical representation as well as to reflect the diversity of related disciplines and sectors of urban life.

Within this context the UN-HABITAT and UNPFII have requested to CELADE the preparation and presentation of three complementary studies, which will be published in this edition of the Population and Development series. It is about three autonomous studies; therefore, it could have some superpositions or reiterations of some statements or developments.

3 Aide Mémoire "Expert Group meeting on Urban Indigenous Peoples and Migration", 27-29 March 2007, ECLAC, Santiago, Chile. 



\section{Spatial distribution of indigenous peoples in Latin America: a census-based interpretation}

Fabiana Del Popolo ${ }^{4}$

\section{Background and objectives}

Disaggregated data and culturally relevant indicators are urgently needed for the production of social statistics relating to indigenous peoples and the lack of information has been repeatedly deplored in national and international circles. Renewed demands are emerging in a socio-political context marked by the more prominent role being assumed by indigenous groups, by advances in the recognition of their historical claims, and by the existence today of an international standard for the individual and collective human rights of indigenous peoples (ECLAC, 2006). Information is a key instrument for monitoring and assessing compliance with those standards, on the understanding that the guarantee and exercise of such collective rights transcends the rural/urban divide.

\footnotetext{
${ }^{4}$ Latin American and Caribbean Demographic Center (CELADE) - ECLAC Population Division. Part of this document was prepared by the author for the Social Panorama of Latin America 2006 (Chapter III, ECLAC). The author acknowledges the valuable comments of Ana María Oyarce to a draft of this document and thanks the support of Mario Acuña in data processing. Of course, the author is responsible of the final contents of the paper.
} 
In response to the foregoing and in keeping with the recommendations of the Permanent Forum on Indigenous Issues (UNPFII), CELADE - Population Division of ECLAC has been conducting a series of activities in order to generate and analyze socio-demographic information on indigenous peoples which can be used as inputs for public policies.5 To do this, CELADE has drawn on the potential of the population censuses, while recognizing the need to reinterpret data from a rights-based perspective. As part of these activities, this document seeks to provide an overview of the territorial location of the indigenous populations of Latin America.

Census micro data from 10 countries in the region have been processed and the results will be examined in an attempt to respond to the following questions:

a) Are indigenous populations still overwhelmingly rural?

b) Is there consistency in the pattern of rural/urban location of specific peoples?

c) Do such peoples have a specific pattern of location within the territory (enclaves, agglomerations, areas of concentration)?

d) Does this pattern differ from that observed for non-indigenous populations?

e) What is the pattern of distribution of indigenous populations within the urban system?

f) What is the pattern of location of indigenous populations within cities? The combination of these four propositions (assumptions) is what makes the desired system and routes to it so complex.

\section{Conceptual and methodological considerations}

\subsection{Anchoring the difference: the relationship of indigenous peoples to territory ${ }^{6}$}

According to various authors, a continuous and prolonged occupation has resulted in indigenous peoples having a deep sense of "belonging" to a territory. The territory has witnessed their history and way of life and harbours a complex network of symbols associated with sacred sites that become a "spiritual subject", a place that has been "walked, sown and consecrated", in the words of indigenous people themselves (National Indigenous Organization of Colombia (ONIC), 2002). Indigenous peoples have emphasized this indissoluble tie to the earth and the practice of territoriality in the physical, social and symbolic senses, which has been defined as the "anchor of their distinctiveness" (Toledo, 2005), while other authors talk of "cultural anchoring" or use the concept of communality (cited by González Chévez, 2001). Territory is not only a geographical and physical place, but a social and cultural space focused around the kinship ties that form the basis of the community.

Broadly speaking, indigenous peoples nowadays define themselves with reference to a territory and a particular way of living there, rather than to the use of a language or way of life and specific social and cultural practices. In this sense, the distinction between land and territory is a key one, with the former understood as a means of production ${ }^{7}$ and the latter as a culturally-constructed life

5 For further details, see the CELADE web page www.cepal.org/celade.

6 Some points examined in this document were used as inputs in the preparation of the chapter on indigenous peoples in the ECLAC publication Social Panorama of Latin America, 2006.

7 Land requirements depend on the economic livelihood of each indigenous people and the activities engaged in, such as hunting, fishing or agriculture and how these take place (continuous cropping or crop rotation, for example). The proportion of productive and fertile land must also be taken into account (Renshaw, 2004). It is not surprising therefore that some peoples require large areas of land in relation to their population size. 
environment (Bartolomé, 1997). The concept of territoriality has therefore served as the basis for the demands of indigenous movements, thereby making territory an aspect of identity (Toledo, 2005), and is one of the rights inherent to the principle of self-determination. This is reflected in the United Nations Declaration on the Rights of Indigenous Peoples, which enshrines rights including the right to possess, use, develop and control their lands, territories and natural resources, and urges States to ensure legal protection and recognition for the full exercise of that right.

The periods of conquest, colonization and expansion of the new republics had a profound effect on indigenous settlements and their ancestral territories, ${ }^{8}$ and a considerable impact on their subsequent reconfiguration. The colonization of the so-called "empty spaces" by States in the nineteenth century for mainly geopolitical reasons (Rodríguez, 2002) resulted in the invasion and pillaging of indigenous territories. Subsequent settlement movements towards the interior of each country saw geopolitical and economic factors combine with demographic and regionalistic ones, along with economic diversification, which promoted the formation of urban settlements. This led to a rearrangement in the spatial distribution of the hegemonic society and consolidated the appropriation of indigenous spaces, lands, territories and natural resources. In a sense, current territorial conflicts between indigenous peoples and rural settlers are one of the negative after-effects of that process.

With the consolidation of market economies and profound structural transformations within States during the last two decades of the twentieth century, indigenous lands again fell victim to the increasing advance of development projects such as dams, highways, bridges, mining, large-scale timbering and oil exploration and extraction (Deruyttere, 1997; United Nations, 2006; IWGIA, 2006). This led to invasions, pillaging and consequent indigenous migrations (Daes, 2001).

The demographic dimension is another important factor in territorial redistribution. On the one hand, high levels of mortality can bring about a sharp drop in a indigenous people's population. ${ }^{9}$ Mention should be made of the high demographic vulnerability of Amazonian peoples in Bolivia: a total of 10 indigenous peoples were wiped out during the twentieth century as a result of contact with the outside world (Valenzuela, 2004). On the other hand, some indigenous peoples are sustaining elevated growth rates thanks to high fertility and the decrease in mortality. This population pressure on land that is degraded, insufficient or invaded by settlers triggers outmigration from the communities of origin.

Migration, however diverse its causes, is recognized as the main force that reorders spatial distribution. The growing urbanization of indigenous populations implies far-reaching sociocultural transformations that affect not only these indigenous peoples but also non-indigenous populations resident in the destination cities. It also poses major challenges for States to design and implement public policies for the construction of a pluricultural society.

\subsection{Political and administrative units: the limits of information}

The present study of territorial distribution starts out with the conventional urban/rural division, before moving on to political and administrative units in an attempt to produce a comparative analysis of the 10 countries selected. A number of relevant points need to be considered in assessing the scope of the analysis.

In terms of territorial rights, statistical systems should be able to provide information on the various aspects (social, demographic, biotic, physiographical, etc.) of indigenous territories, including the location of human settlements and their spatial distribution. One key element is being able to determine the geographical boundaries of the territory, considering the real limits of

\footnotetext{
${ }^{8}$ Refers to the territories occupied by indigenous peoples at the time of the arrival of the European conquistadors.

9 This occurred with the Xavánte people of Pimental Barbosa or Etéñitépa (Brazil), who suffered a population crisis from the 1940s due to epidemics and violence (Ventura Santos, Flowers and Coimbra Jr, 2005).
} 
sociocultural interaction of each people. However, this can be a difficult task when several ethnic groups live in the same territory or when members of a certain indigenous people extend over a large part of the country (as in Guatemala and Mexico). Political will is another important factor. ${ }^{10}$

Although most Latin American countries have made significant progress in the constitutional and even legal recognition of indigenous territories, the implementation of that recognition in the region has been sadly lacking (Toledo, 2005). This is reflected in the lack of information in the region regarding indigenous territorial units. There is insufficient mapping of those territories for the purposes of meaningful georeferencing. Panama has made some advances, with the creation of five indigenous communal landholdings (comarcas), ${ }^{11}$ as has Costa Rica, with 22 legally and administratively defined territories (Solano, 2004), which can be linked with census information. In Paraguay and the Bolivarian Republic of Venezuela (the only countries to carry out an indigenous census in the early 2000s), communities are geographically identified in census databases. The Brazilian Geographical and Statistical Institute (IBGE) incorporates the cartography of the Indian National Foundation (FUNAI) on indigenous reserves or protected areas, although the territorial boundaries do not always coincide, as only legally recognized areas are circumscribed by the Institute. ${ }^{12}$

Beyond these specific cases, political and administrative units do not tend to coincide with indigenous territories, even when smaller scale divisions are used. The impact on analysis is even greater as far as indigenous peoples themselves are concerned: the Mixtecos in Mexico, for instance, are spread over three federal states. In Panama, according to the 2000 census, $52.5 \%$ of all indigenous population resided in indigenous comarca (landholdings), while $47.5 \%$ lived elsewhere. However, although indigenous landholdings function as administrative units, only the Kuna, Ngöbe and Emberá peoples have been able to obtain legislation for their comarca. Nonetheless, the Buglé and Wounnan peoples (in the Ngöbe and Emberá districts, respectively) are demanding their own comarcas, as are the Naso Teribe and Bri Bri peoples (IDB/ECLAC, 2005c). Also, where demarcations exist, they do not necessarily correspond to their territories. This is the case for the Ngöbe people, $60 \%$ of whom live in the landholding of the same name; the great majority of the remainder live in the neighbouring provinces of Bocas del Toro and Chiriquí, with a significant presence in the rural areas surrounding the comarca.

Notwithstanding the above, indigenous peoples are part of national States and it therefore makes sense, in terms of policies and programmes, to look into their territorial location on the basis of the country's political and administrative divisions. The indigenous peoples themselves also need a similar overview, not only because they have settlements beyond their territories, but also because having their own interpretations of regional and national dynamics will make it easier for them to position themselves and stand them in better stead for becoming genuine stakeholders (Gamboa, 2006).

In short, studies on the territorial distribution of indigenous peoples should draw attention to their ancestral territories and the settlements outside them. One potential solution to be considered during the 2010 round of censuses could be to redefine census segments with a view to statistically

10 Ecuador and Mexico have adopted methodological approaches that aim to identify indigenous settlements and communities within a geographical space for the purposes of public policymaking. They basically identify indigenous municipalities or localities based on the relative numbers involved (Serrano, Embriz and Fernández Ham, 2002 and CODENPE, 2001). In both countries, there are constraints owing to their political and administrative divisions.

11 The landholdings of Kuna Yala (1953), Ngöbe Buglé (1997) and Emberá (1983, changed to Emberá Wounaan by decree in 1999) are first-level political and administrative areas and Kuna de Madungandí (1998) and Wargandí (2000) are resettlements (third level).

12 The Indian National Foundation (FUNAI) recognizes 604 indigenous lands, 480 of which are demarcated and approved or in the demarcation process, and 124 of which are in the process of being identified or recognized (International Work Group for Indigenous Affairs (IWGIA), 2006). 
reconstructing indigenous territories as valid jurisdictions, which can already be done in Brazil and Costa Rica. This would clearly have to be carried out with the full participation of the indigenous peoples. Some agencies, such as the National Institute for the Development of Andean, Amazonian and Afro-Peruvian Peoples (INDEPA) in Peru, have made significant progress in territorial demarcation. Progress is needed in the cartographic harmonization of indigenous organizations and agencies and national statistical institutes, with a view to making the most of census data and other information. It is also clear that the census question about self-definition remains indispensable for a comprehensive overview of the various areas (inside and outside their territories).

In the case of urban settlements (outside the ancestral territories), ${ }^{13}$ the individual question on self-identification and the georeferenced disaggregation of census data would provide an initial approximation (at the neighborhood level, for example) and would also enable sociodemographic characterizations to be made. This document illustrates the potential for using the census to work along these lines.

\section{Census results}

\subsection{Rural and urban indigenous groups: two facets of the same peoples}

According to data from the 2000 round, the indigenous population of Latin America stands at at least 30 million, of whom no less than 12 millions (about 40\%) live in urban areas. However, this regional average masks differences between countries.

Broadly speaking, high percentages of indigenous population in rural areas correspond to ancestral territories and displacement areas to which they have been reduced. As shown in figure 1, in half of the 10 countries studied, at least $80 \%$ of the indigenous population lives in rural areas (Costa Rica, Ecuador, Honduras, Panama and Paraguay). In Guatemala and Mexico about one in three indigenous individuals lives in urban areas, while in the remaining three countries (Bolivia, Brazil and Chile) over half of the indigenous population live in cities (particularly in Chile, where the proportion rises to $64.8 \%$ ).

Several factors have influenced internal migration from rural to urban areas, including lack of territory, demographic pressure on land, the interests of national and multinational corporations, environmental degradation, poverty, water shortages and the quest for better economic and educational opportunities. ${ }^{14}$ These factors interact in different ways depending on the historical and territorial context, thereby generating considerable heterogeneity among peoples.

In the two countries with the highest proportion of urban indigenous population, the situation is practically unrelated to the people of origin. There are high levels of urbanization among all the five main peoples in Bolivia and the eight peoples recognized in the census in Chile. In Bolivia, however, Chiquitanos and Mojeños do settle in cities more than the average (figure 2). In Chile, $62.4 \%$ of Mapuches live in urban areas, while the proportion is significantly higher (over $80 \%$ ) among the seven other indigenous peoples. The national context (in this case the country's level of urbanization) does influence how many members of the same people live in urban areas. Examples include the different results for the Aymara and the Quechua in Bolivia and Chile (see figure 2).

13 Refers to territories occupied by indigenous peoples and where common law was practised at the time of the arrival of the European conquistadors.

14 A qualitative study carried out in Panama showed that one of the main reasons why Kunas migrate from their comarcas (landholding) to Panama City was the lack of secondary and higher education options (UNDP, 2002). This mobility is also kinship-based and collective. 
Figure 1 DISTRIBUTION OF INDIGENOUS AND NON-INDIGENOUS POPULATION BY AREA OF RESIDENCE, 2000 ROUND OF CENSUSES

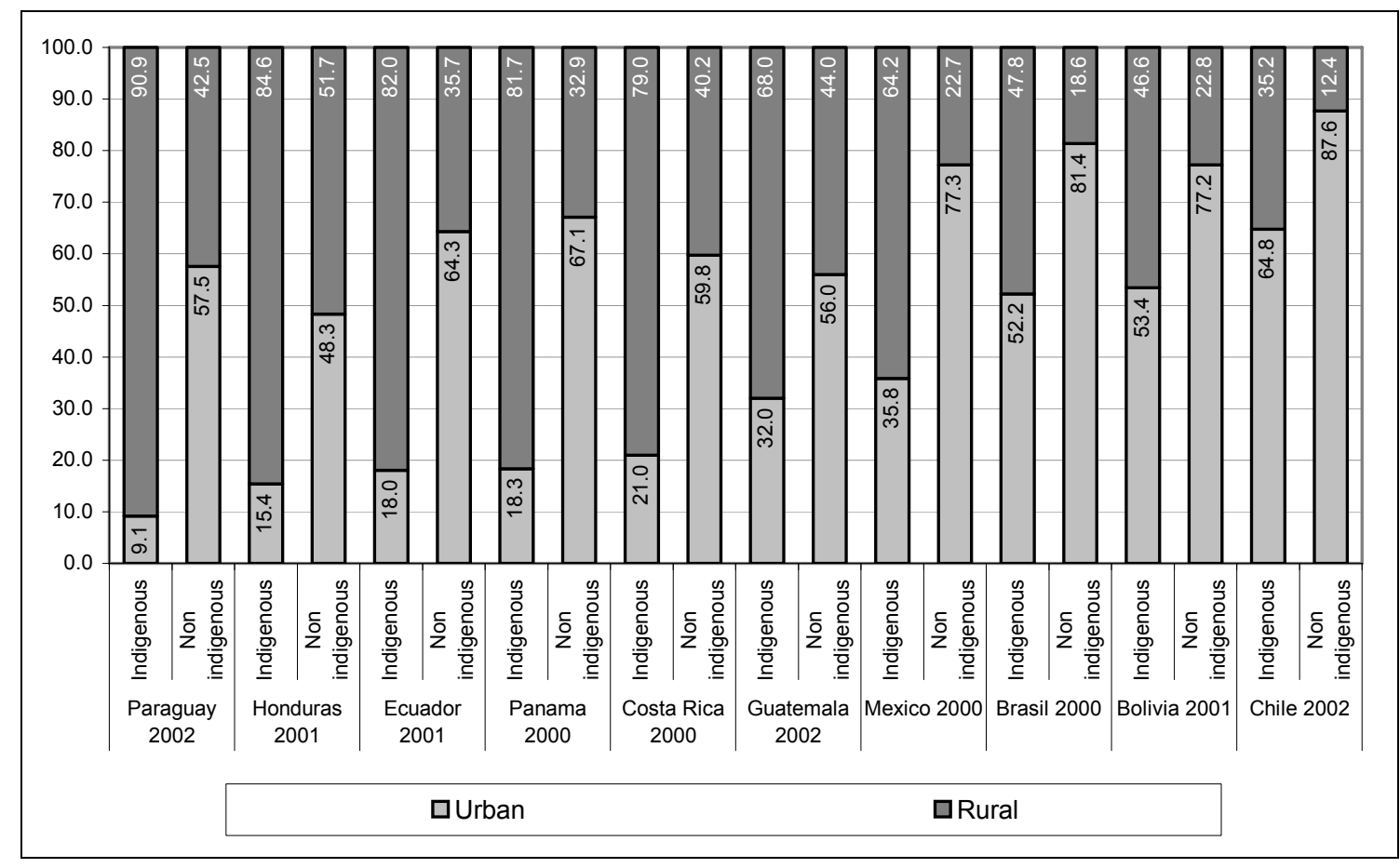

Source: CELADE-Population Division of ECLAC, special processing of census microdatabases.

Figure 2

INDIGENOUS PEOPLES BY AREA OF RESIDENCE, GROUP OF ORIGIN AND URBAN NONINDIGENOUS POPULATION, 2000 ROUND OF CENSUSES

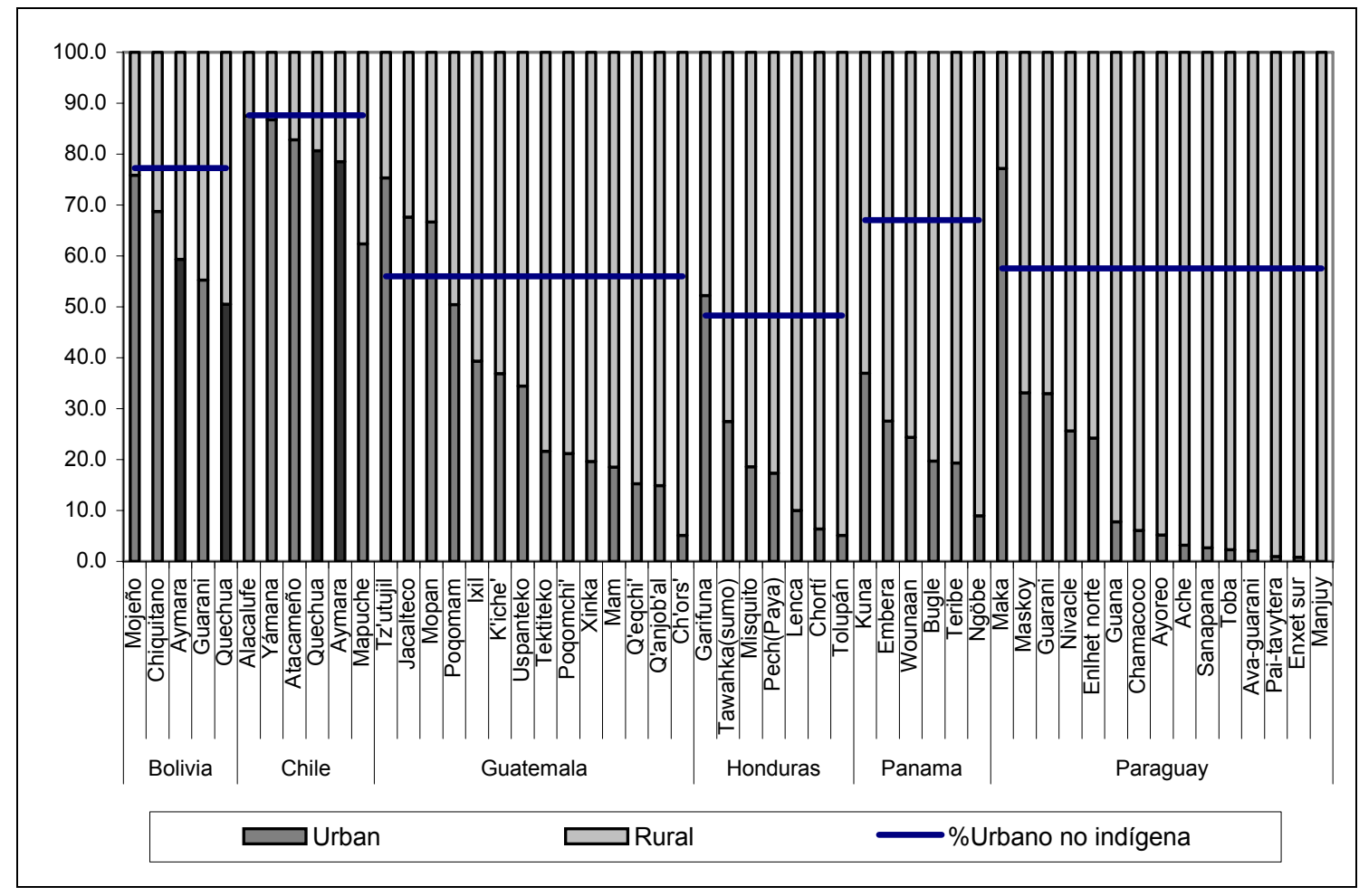

Source: CELADE-Population Division of ECLAC, special processing of census microdatabases. 
In countries where the indigenous population is predominantly rural, the size of urban settlements varies according to the indigenous group concerned (as shown in figure 2). In Guatemala, for instance, whereas the Q'eqchi', Mam and Q'anjob'al peoples live mostly in rural areas, the Tz'utujil, Jacalteco and Mopán peoples live mainly in cities (over 65\% of their population). Similar differences can be observed in all the other countries under consideration.

Despite the proportion of indigenous population living in urban areas, it should be borne in mind that indigenous demands are based on territorial rights as a necessary requirement for developing their identity as autonomous peoples. Guaranteeing the exercise of these rights represents a huge challenge for States in a context of, inter alia, globalization and pressure to control territories and the exploitation of natural resources, among others issues.

In addition, self-recognition among indigenous peoples in urban areas responds to an indigenous consciousness linked to their ancestral territory. Several studies show that urban indigenous peoples maintain their sociocultural systems while in the cities and retain their ties with their communities of origin (Camus, 2002; UNDP, 2002). However, the figures highlight the challenge that growing urbanization poses for indigenous peoples, including the possible loss of culture and identity. For governments, this emphasizes the need to tackle and overcome the problems that indigenous people in urban areas are faced with, including the lack of equal opportunities in terms of access to decent employment and basic services like health and education, and other psychosocial problems resulting from the loss of traditional support networks (Del Popolo and Oyarce, 2005). The intercultural approach cannot be ignored in the search for solutions; it provides the only way to guarantee the right of indigenous peoples to cultural integrity.

\subsection{Focusing on regions of indigenous settlement: distribution by major administrative division}

The results of the 2000 round of censuses demonstrate that, in the 10 countries considered, the indigenous population is spread out over most of each country's territory. It is generally possible to determine which major administrative divisions have been home to indigenous settlements since before the European conquest, and those where indigenous populations have resettled. Furthermore, an analysis by people of origin (or failing that, by language spoken) shows the indigenous peoples diversity that live in any given area.

The main point illustrated by table $1^{15}$ is the different territorial distribution of indigenous and non-indigenous populations. The distribution of the indigenous population is mostly in areas that include their ancestral territories, and thus this population is predominantly rural, while the distribution of the non-indigenous population is more associated with the country's main city or metropolitan area, and consequently is predominantly urban. This typical pattern of the hegemonic society was consolidated in the twentieth century (Rodríguez, 2002).

Also noteworthy is that, in six of the 10 countries under review (Bolivia, Brazil, Chile, Costa Rica, Ecuador and Panama), the area including the largest city or the national capital is home to some of the highest proportions of indigenous population, although the latter is never in first place (except in Bolivia). In the other four countries (Guatemala, Honduras, Mexico and Paraguay), the metropolitan areas definitely have a lower proportion of indigenous groups. The non-indigenous population is predominant in metropolitan areas compared with the indigenous population (except in Honduras and Mexico).

15 The table includes those administrative divisions having the highest proportion of indigenous population, which total at least $50 \%$ of the country's indigenous population. 
In order to summarize the differences in territorial distribution by major administrative division, the Duncan dissimilarity index was calculated as presented in figure $3 .{ }^{16}$ High values (those close to 1 ) show the differences between the distribution of indigenous and non-indigenous populations for all countries except the most urbanized ones (Bolivia, Brazil and Chile). In other words, the geographical location of the indigenous population is very different from that of the non-indigenous population, as the former tend to live mainly in settlements linked to ancestral territories.

Table 1

PERCENTAGE OF THE INDIGENOUS AND NON-INDIGENOUS POPULATIONS IN THE LARGEST MAJOR ADMINISTRATIVE DIVISION (DAM) ${ }^{\text {a }}$ AND PERCENTAGE LIVING IN URBAN AREAS IN THE RESPECTIVE DIVISION, 2000 ROUND OF CENSUSES

\begin{tabular}{|c|c|c|c|c|c|c|}
\hline \multirow[b]{2}{*}{ Country } & \multicolumn{3}{|c|}{ Indigenous } & \multicolumn{3}{|c|}{ Non indigenous } \\
\hline & DAM & $\begin{array}{c}\% \text { of national } \\
\text { total }\end{array}$ & $\%$ urban & DAM & $\begin{array}{c}\% \text { of national } \\
\text { total }\end{array}$ & $\%$ urban \\
\hline \multirow{4}{*}{ Bolivia } & La Paz & 35.9 & 59.9 & Santa Cruz & 40.7 & 80.5 \\
\hline & Cochabamba & 21.4 & 50.5 & La Paz & 16.3 & 87.9 \\
\hline & Santa Cruz & 14.7 & 70.0 & Cochabamba & 11.3 & 84.3 \\
\hline & Potosí & 11.7 & 27.2 & Tarija & 10.0 & 61.1 \\
\hline \multirow{6}{*}{ Brazil } & Amazonas & 15.4 & 16.6 & São Paulo & 21.9 & 93.4 \\
\hline & Bahia & 8.8 & 72.0 & Minas Gerais & 10.6 & 81.9 \\
\hline & São Paulo & 8.7 & 92.2 & Rio de Janeiro & 8.5 & 96.0 \\
\hline & Mato Grosso do Sul & 7.3 & 21.7 & Bahía & 7.7 & 67.0 \\
\hline & Minas Gerais & 6.6 & 77.5 & Rio Grande do Sul & 6.0 & 81.7 \\
\hline & Rio Grande do Sul & 5.3 & 61.9 & Paraná & 5.7 & 81.4 \\
\hline \multirow{4}{*}{ Chile } & La Araucanía & 29.5 & 29.2 & Metropolitana & 40.7 & 96.9 \\
\hline & Metropolitana & 27.7 & 98.4 & Del Bío Bío & 12.5 & 82.5 \\
\hline & Los Lagos & 14.7 & 47.1 & Valparaíso & 10.5 & 91.5 \\
\hline & Del Bío Bío & 7.8 & 68.1 & Los Lagos & 6.7 & 70.7 \\
\hline \multirow{3}{*}{ Costa Rica } & Limón & 39.2 & 12.6 & San Jose & 35.6 & 80.6 \\
\hline & Puntarenas & 23.5 & 8.7 & Alajuela & 19.0 & 36.3 \\
\hline & San José & 14.4 & 66.5 & Cartago & 11.5 & 66.9 \\
\hline \multirow{4}{*}{ Ecuador } & Chimborazo & 18.5 & 5.0 & Guayas & 28.8 & 81.8 \\
\hline & Pichincha & 11.5 & 50.3 & Pichincha & 20.2 & 72.7 \\
\hline & Imbabura & 10.5 & 13.4 & Manabí & 10.4 & 51.9 \\
\hline & Cotopaxi & 10.1 & 3.5 & Los Ríos & 5.7 & 50.2 \\
\hline \multirow{4}{*}{ Guatemala } & Alta Verapaz & 15.6 & 17.0 & Guatemala & 33.2 & 88.8 \\
\hline & Quiche & 12.6 & 22.9 & San Marcos & 8.2 & 27.0 \\
\hline & Huehuetenango & 12.0 & 17.1 & Escuintla & 7.5 & 48.1 \\
\hline & Chimaltenango & 7.7 & 43.2 & Jutiapa & 5.7 & 27.4 \\
\hline \multirow{3}{*}{ Honduras } & Lempira & 25.0 & 5.1 & Francisco Morazan & 19.3 & 77.1 \\
\hline & Intibuca & 17.4 & 11.1 & Cortes & 18.8 & 73.3 \\
\hline & Gracias a Dios & 11.7 & 15.1 & Yoro & 7.6 & 44.4 \\
\hline \multirow{4}{*}{ Mexico } & Oaxaca & 23.9 & 30.4 & México & 14.1 & 86.4 \\
\hline & Chiapas & 13.8 & 26.2 & Distrito Federal & 9.4 & 99.8 \\
\hline & Yucatán & 9.2 & 68.0 & Veracruz & 7.0 & 62.0 \\
\hline & Veracruz & 9.0 & 23.0 & Jalisco & 7.0 & 84.6 \\
\hline \multirow{3}{*}{ Panama } & Comarca Ngobe Bugle & 37.4 & 0.0 & Panamá & 52.8 & 89.6 \\
\hline & Bocas del Toro & 17.3 & 0.0 & Chiriquí & 13.3 & 46.8 \\
\hline & Panamá & 14.1 & 77.4 & Veraguas & 8.0 & 28.7 \\
\hline \multirow{3}{*}{ Paraguay } & Boquerón & 22.7 & 27.7 & Central & 26.8 & 86.4 \\
\hline & Presidente Hayes & 22.5 & 0.1 & Alto Paraná & 10.9 & 66.9 \\
\hline & Amambay & 12.1 & 1.3 & Asunción & 10.1 & 100.0 \\
\hline
\end{tabular}

Source: Latin American and Caribbean Demographic Centre (CELADE) - Population Division of ECLAC, special processing of census microdatabases.

${ }^{\text {a }}$ The principal major administrative divisions are those that have the largest indigenous or non-indigenous population, as appropriate.

16 The Duncan dissimilarity index varies between 0 and 1 : the nearer to one, the more unequal the distribution between indigenous and non-indigenous population. It can also be interpreted as the percentage of the indigenous population that would have to change their area of residence to achieve an equal distribution. 

DIVISION OF INDIGENOUS AND NON-INDIGENOUSPOPULATIONS, BY AREA OF RESIDENCE, $\begin{array}{r}2000 \text { ROUND OF CENSUSES } \\ \hline\end{array}$

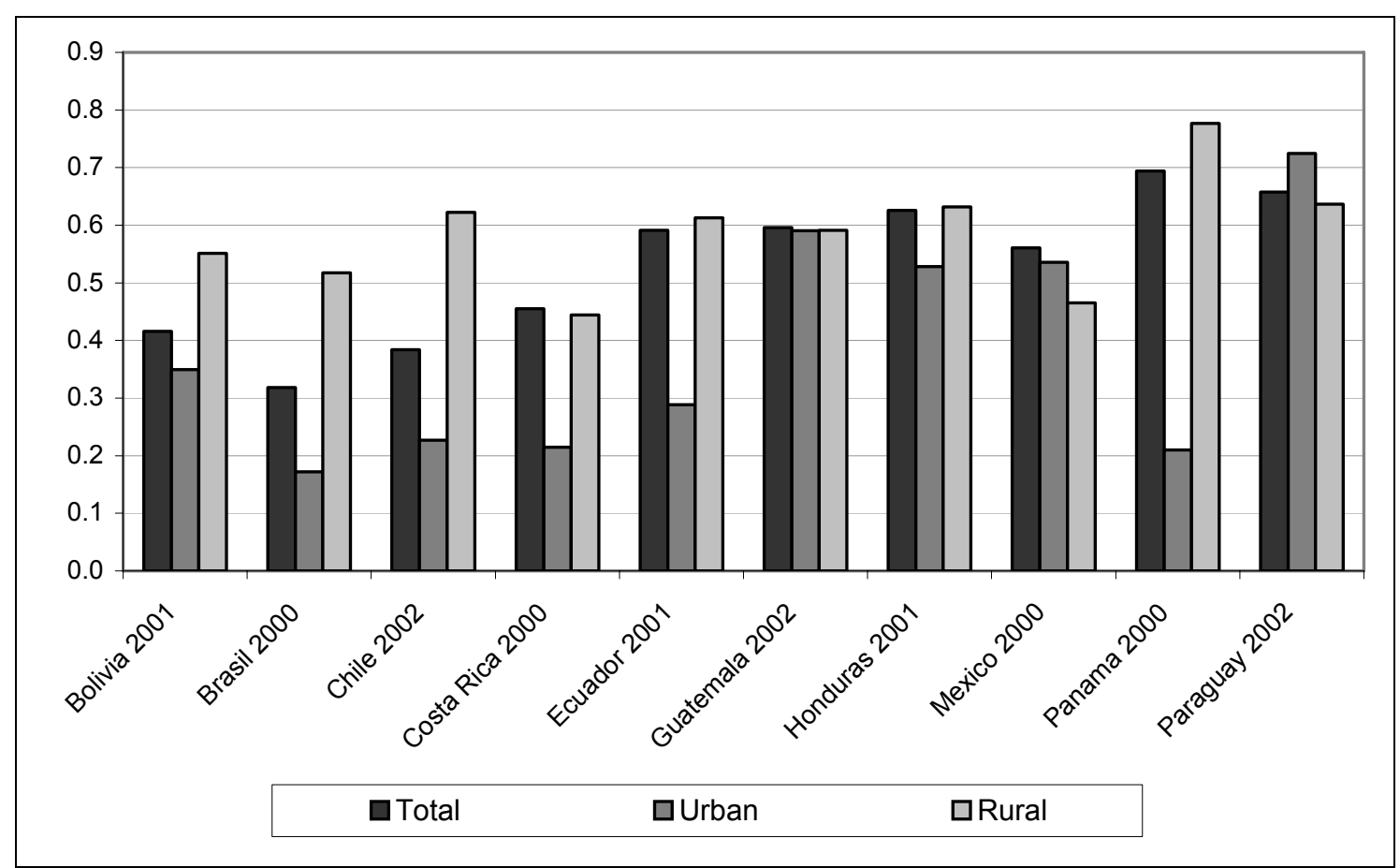

Source: Latin American and Caribbean Demographic Centre (CELADE) - Population Division of ECLAC, special processing of census microdatabases.

In terms of the areas of residence, it is interesting to note that the territorial distribution of the urban indigenous population is not significantly different from that of the non-indigenous urban population in Bolivia, Brazil, Chile, Ecuador, Costa Rica and Panama. However, the patterns of rural settlement do differ significantly (although less so in Costa Rica). In Guatemala, Honduras, Mexico and Paraguay, there are considerable differences in territorial distribution based on ethnicity in both urban and rural areas. Considering that it is no coincidence that indigenous populations live in areas with less access to basic services and higher levels of poverty, these results show how urgent it is to formulate policies based on territorial location. As Delaunay (2003) concludes in the case of Mexico, offering integration to people rather than to regions encourages social discrimination against the indigenous population as a whole, encouraging indigenous people (in the event of migration or upward social mobility) to abandon their ethnic references, which in turn contributes to the dissolution of cultural diversity.

The data in table 1 should be complemented by taking into account the different indigenous peoples in each country. By way of example, four situations drawn from selected countries of the Southern Cone are described below.

In Chile, the territorial distribution of the indigenous population is dominated by the Mapuche people, who make up $87.3 \%$ of the country's indigenous population. Yet these aggregate figures do not show, for instance, that $84.4 \%$ of the second-largest indigenous group (the Aymara) live in the First Region in the north (Tarapacá), and that, of the Atacameño people, $66 \%$ live in Antofagasta (Second Region) and 14.4\% live in Atacama (Third Region). Although knowing which areas have the highest concentration of indigenous population is important for policymaking, in the context of recognition for indigenous peoples, demographic weight is not the only factor to consider, as distinctions also need to be made for each indigenous people. 
In Ecuador, over half of the indigenous population lives in the mountain provinces of Chimborazo, Pichincha, Imbabura and Cotopaxi, as a result of the inter-Andean Quechua domination of the pre-Inca period. There are currently 13 indigenous peoples or nationalities in the mountains, whose members all speak languages belonging to the Quechua or Kichwa family. In addition, almost $20 \%$ of the total indigenous population lives in the six Amazonian provinces.

Brazil has over 200 indigenous peoples, speaking about 180 languages (Pagliaro, Azevedo and Ventura Santos, 2005). Of this indigenous population, 29\% lives in the north of the country (particularly in the state of Amazonas), including the Yanomami, Macuxi, Awá, Kaixana, Ticuna, Wai Wai, Hixcariana, Kokama, Ti Mirim and Ti Araca peoples, plus some groups living in voluntary isolation. Another $45 \%$ are divided almost equally between the north-east and south-east regions, mainly in Bahía and São Paulo (such as the Karajá, Xavante and Tupinkin peoples); and the remainder of the indigenous population live in the southern states and mostly speak languages of the Guaraní family. The fact that the state of São Paulo has the third largest indigenous population (the state is home to $9 \%$ of the country's indigenous people) reflects mobility towards urban centres.

Lastly, Bolivia is an exceptional case. The two main areas are home to the two largest peoples (Quechua and Aymara) and the third major administrative division with indigenous presence is characterized by a variety of indigenous peoples: Guaranís, Chiquitanos and other Amazonian peoples, plus a significant proportion of Quechuas and - to a lesser extent - Aymaras, as a result of a series of waves of migration since the mid-nineteenth century (IDB/ECLAC, 2005a).

In summary, the areas with the largest indigenous population are determined by the presence of the largest indigenous group (Chile, Honduras and Panama); of groups belonging to the same linguistic family (Ecuador and Guatemala); of various indigenous peoples (Brazil, Costa Rica, Mexico and Paraguay); and, in the case of Bolivia, of the two largest indigenous groups living in the two main administrative divisions, with a third major area characterized by a diversity of indigenous peoples.

Another interesting line of enquiry is to examine the number of indigenous people as a proportion of the total population in each area. In some countries, considering those areas with the largest indigenous presence (in relation to total population in each major administrative area), these administrative divisions are almost entirely populated by indigenous people. This is true of Potosí, La Paz, Cochabamba and Oruro in Bolivia; Totonicapán, Solola, Alta Verapaz, Quiche and Chimaltenango in Guatemala; Gracias a Dios in Honduras; and the three comarcas in Panama. In other countries, indigenous population represent between $40 \%$ and $55 \%$ of the population of such areas, as in Napo and Morona Santiago (Ecuador), Lempira and Intibucá (Honduras), Oaxaca (Mexico) and Boquerón (Paraguay). In other cases, indigenous people are minorities that make up less than $10 \%$ of the population, for example, in Roraima and Amazonas (Brazil) and in Limón and Puntarenas (Costa Rica).

The gender breakdown of the population in each area varies from country to country; some areas show a female majority, some balanced proportions and some a predominance of men. This is mainly a result of both internal and international migration, and may also reflect differential declarations of ethnic status. Each indigenous people has its own mobility patterns, sometimes associated with different stages of the life cycle which determine who is to migrate. In terms of general trends, Brazil, Chile and Costa Rica show greater numbers of indigenous women in the area containing the largest city or the metropolitan region, while areas associated with ancestral territories have more men. In Ecuador and Panama the opposite applies, except in the comarca of the Emberá people.

For Bolivia and Guatemala, it is more difficult to schematize the results as there is such a large indigenous population and so much diversity in terms of peoples. Broadly speaking, in Guatemala, the predominance of indigenous women both in the main areas of indigenous 
population and in the department of Guatemala seems to be the result of selective international migration. In Paraguay, most areas have a male majority. In Mexico, areas with a higher proportion of indigenous people show a balanced composition in terms of gender, except for Oaxaca and the State of Mexico, where women are in the majority. In half of all the federal states (16) men dominate, there is a balance in four, and in the remaining states (12) there are more women in indigenous areas.

\subsection{Spatial distribution on a smaller territorial scale}

The allocation of resources and the implementation of targeted policies require the most precise territorial identification possible for each people. Although municipal demarcations have their disadvantages in terms of not corresponding to indigenous territories, decentralization processes in Latin American countries mean that local authorities have a greater role in solving the socioeconomic problems affecting indigenous peoples. In addition, it is through these very channels that indigenous peoples are becoming empowered. It is therefore important to identify municipalities with a high proportion of indigenous population.

Table 2 presents an approach to the description of an indigenous territorial settlement at the municipality level. For this purpose, municipalities with an indigenous presence (at least 50 indigenous persons $)^{17}$ were used. Practically all municipalities in Bolivia and Guatemala satisfy this requirement, while for the rest of countries, except Brazil and Paraguay, more than half of the municipalities have an indigenous presence, with various multicultural situations. No direct relationship would appear to exist between these results and the proportion of indigenous population that there are in the country (see, for example, Ecuador and Honduras, or Costa Rica and Paraguay). Brazil and Paraguay are the only countries in which most of the indigenous population is concentrated in relatively few municipalities. ${ }^{18}$

Focuses on the ethnic composition of the municipalities with an indigenous presence, Table 2 reveals a wide variety of situations. At one extreme is Bolivia, where $60 \%$ of the municipal divisions are essentially indigenous $(70 \%$ or over) and where very few municipalities have a low representation or a small number of indigenous persons. At the other extreme is Brazil, where almost half of the indigenous population is spread over a number of municipalities and constitutes minorities. Chile, Costa Rica and Paraguay have practically no municipalities where indigenous persons are in the majority; in most cases, indigenous persons account for less than $20 \%$ of the population, and only in the case of Chile are there municipalities with a strong presence of indigenous person in absolute terms (over 5000).

17 In a preliminary estimate, account was taken of the number of municipalities with at least one indigenous person. The results corresponded to practically $100 \%$ of municipalities, except in the cases of Brazil and Paraguay. Subsequently, an examination of the composition of these municipalities revealed that the vast majority of them had a very limited number of indigenous persons. Thus, to refine the study, the minimum of 50 indigenous persons was established. This is an arbitrary limit and should be reviewed when undertaking national studies.

18 It will be recalled that in the case of Paraguay, these results may be skewed by the fact that the general census detected a very small indigenous population, probably owing to flaws in the design of the census schedule. 
Table 2 DISTRIBUTION OF INDIGENOUS POPULATIONS IN TERMS OF THE PROPORTION THEY REPRESENT OF MUNICIPAL POPULATIONS DISTRIBUTION OF INDIGENOUS POPULATIONS IN TERMS OF THE PROPORTION THEY RE

\begin{tabular}{|c|c|c|c|c|c|c|c|c|c|c|}
\hline \multirow[b]{2}{*}{ Municipalities and population } & \multicolumn{10}{|c|}{ Countries } \\
\hline & $\begin{array}{l}\text { Bolivia } \\
2^{2001}{ }^{a}\end{array}$ & Brazil & $\begin{array}{l}\text { Chile } \\
2002^{\text {b }}\end{array}$ & $\begin{array}{c}\text { Costa Rica } \\
2000^{c}\end{array}$ & Ecuador $^{c}$ & $\begin{array}{l}\text { Guatemala } \\
2001\end{array}$ & $\begin{array}{l}\text { Honduras } \\
2001\end{array}$ & $\begin{array}{c}\text { Mexico } \\
2000\end{array}$ & $\begin{array}{l}\text { Panama } \\
2000^{\mathrm{d}}\end{array}$ & $\begin{array}{l}\text { Paraguay } \\
\text { 2002 }^{\mathrm{d}}\end{array}$ \\
\hline Total municipalities & 314 & 5,507 & 342 & 81 & 220 & 331 & 298 & 2,443 & 75 & 241 \\
\hline$\%$ of municipalities with more than 50 indigenous persons (IP) & 98.7 & 24.2 & 90.6 & 74.1 & 86.8 & 96.7 & 52.3 & 63.0 & 76.0 & 31.5 \\
\hline$\%$ municipalities with more than $70 \%$ IP & 65.2 & 0.2 & 0.6 & 0.0 & 4.2 & 43.4 & 7.7 & 26.7 & 17.5 & 0.0 \\
\hline$\%$ municipalities with $40 \%-69 \%$ IP & 12.9 & 0.5 & 5.5 & 1.7 & 6.8 & 9.1 & 32.1 & 10.2 & 5.3 & 9.2 \\
\hline$\%$ municipalities with $20 \%-39 \%$ IP & 11.9 & 1.7 & 5.8 & 1.7 & 11.0 & 7.5 & 9.6 & 7.7 & 7.0 & 6.6 \\
\hline$\%$ municipalities with less than $20 \%$ IP and over 5,000 IP & 0.6 & 1.1 & 8.1 & 1.7 & 5.8 & 5.0 & 1.9 & 4.3 & 7.0 & 1.3 \\
\hline$\%$ municipalities with less than $20 \%$ IP and 2,000 to 4,999 IP & 1.0 & 2.7 & 13.9 & 6.7 & 6.3 & 8.4 & 4.5 & 5.7 & 12.3 & 2.6 \\
\hline$\%$ municipalities with less than $20 \%$ IP and 50 to 1,999 IP & 8.4 & 93.8 & 66.1 & 88.3 & 66.0 & 26.6 & 44.2 & 45.4 & 50.9 & 80.3 \\
\hline \multirow[t]{2}{*}{ Total municipalities with more than $50 \mathrm{IP}$} & 100.0 & 100.0 & 100.0 & 100.0 & 100.0 & 100.0 & 100.0 & 100.0 & 100.0 & 100.0 \\
\hline & 310 & 1,330 & 310 & 60 & 191 & 320 & 156 & 1,538 & 57 & 76 \\
\hline Total population in municipalities with IP & в 049325 & 100465523 & 14002214 & 2533345 & 11006454 & 10716180 & 3995847 & 71804398 & 2408578 & 1119600 \\
\hline \multirow{2}{*}{$\begin{array}{l}\text { \% indigenous persons in municipalities with IP compared } \\
\text { with the total population of these municipalities } \\
\% \text { indigenous persons in municipalities with IP in relation to } \\
\text { total indigenous population }\end{array}$} & 62.2 & 0.6 & 4.8 & 2.4 & 7.5 & 42.9 & 10.5 & 8.4 & 11.7 & 7.5 \\
\hline & 100.0 & 86.9 & 97.7 & 94.8 & 98.8 & 99.7 & 97.8 & 98.7 & 98.9 & 95.2 \\
\hline$\%$ indigenous population in municipalities with over $70 \%$ IP & 60.3 & 4.2 & 0.3 & 0.0 & 14.5 & 76.4 & 19.6 & 47.1 & 51.5 & 0.0 \\
\hline$\%$ indigenous population in municipalities with $40 \%-69 \%$ IP & 27.5 & 3.0 & 15.3 & 20.1 & 24.1 & 11.4 & 51.5 & 21.5 & 17.4 & 38.3 \\
\hline$\%$ indigenous population in municipalities with $20 \%-39 \%$ IP & 11.1 & 11.7 & 12.2 & 13.9 & 24.2 & 3.7 & 9.5 & 9.9 & 5.1 & 9.0 \\
\hline $\begin{array}{l}\% \text { indigenous population in municipalities with less than } 20 \% \\
\text { IP and more than } 5,000 \text { IP. }\end{array}$ & 0.7 & 19.1 & 38.6 & 13.0 & 24.9 & 5.5 & 6.4 & 12.6 & 13.8 & 8.6 \\
\hline $\begin{array}{l}\% \text { indigenous population in municipalities with less than } 20 \% \\
\text { IP and } 2,000 \text { to } 4,999 \text { IP. }\end{array}$ & 0.2 & 15.2 & 20.1 & 18.2 & 5.0 & 1.9 & 6.0 & 4.5 & 8.6 & 6.9 \\
\hline $\begin{array}{l}\% \text { indigenous population in municipalities with less than } 20 \% \\
\text { IP and } 50 \text { to } 1,999 \text { individuals. }\end{array}$ & 0.2 & 46.8 & 13.5 & 34.8 & 7.3 & 1.0 & 7.1 & 4.4 & 3.6 & 37.2 \\
\hline \multirow[t]{2}{*}{ Indigenous population in municipalities with IP } & 100.0 & 100.0 & 100.0 & 100.0 & 100.0 & 100.0 & 100.0 & 100.0 & 100.0 & 100.0 \\
\hline & 008897 & 637846 & 676061 & 60562 & 820310 & 4594436 & 418578 & 6020046 & 282075 & 84299 \\
\hline
\end{tabular}

Source: Latin American and Caribbean Demographic Centre (CELADE) - Population Division of ECLAC, special processing of census microdatabases.

NB: Only known values of the ethnic variable have been used in preparing this table.

${ }^{a}$ Municipality is equivalent to "section". Includes persons living in occupied private dwellings. ${ }^{b}$ Municipalities or "communes". ${ }^{c}$ Municipality is equivalent to "canton". ${ }^{d}$

Municipality is equivalent to "district. 
In Mexico, just over a quarter of all municipalities are predominantly indigenous and these account for almost half of the indigenous population. In almost half of the municipalities with an indigenous population, the latter have low numerical representation, amounting to less than 2,000 persons. The situation in Panama is similar: the municipalities with a predominantly indigenous population account for a slightly lower proportion.

Some municipalities show an ethnic composition that is highly varied, consisting of indigenous persons from different peoples as well as non-indigenogus persons. This is the case in Costa Rica, in the municipalities of Talamanca (Limón) and Buenos Aires (Puntarenas). There are also examples of non-indigenous persons and indigenous people (of the same group) coexisting in even proportions, as in the case of the Mapuches living in Nueva Imperial and Padre las Casas (in the Araucanía region, Chile). Lastly, some municipalities are "ethnically homogeneous", consisting almost entirely of indigenous persons of the same group, as in the case of several municipalities of La Paz and Oruro (Bolivia).

In terms of recognition of indigenous peoples and given the wide diversity of situations, a dual or multiresidential approach is needed to study the mobility and geographic location of indigenous peoples in relation to their place of origin (ancestral territory) and their place of destination. In this respect, Quesnel's archipelago concept (that is, a main island surrounded by a series of closely related and interconnected islands) may be useful (Quesnel, 2006). The main island would be the traditional region or territory from which the indigenous people move outwards towards other regions and/or municipalities (or even other countries), and maintain links and relationships with their home communities, while living in the midst of sectors of the population that may consist of other ethnic groups or a mixed population. This approach can be used to analyse the dependency between the territories where members of the same group reside, as well as to identify the needs in both areas, hence, the requirements in terms of specific programmes and policies.

\subsection{Urban indigenous population: new living spaces and inequality reproduced}

\subsubsection{Distribution of indigenous population within the system of cities}

One of the most striking features of urbanization in Latin America is the existence of large metropolitan areas. As pointed out by Rodríguez (2002, p. 33), there are historical reasons why the region has many large cities. "Although the basic settlement pattern in pre-Colombian times was rural, the most powerful civilizations (Incas and Aztecs) built huge cities to concentrate their resources. The urban inclination of the colonizers encouraged them to found many cities as power and defence mechanisms, and they used the native urban networks fairly systematically as a basis for their settlements". Notwithstanding those origins, the big cities really came into being during the twentieth century.

Another noteworthy characteristic of the region is the high concentration of population in the capital cities or metropolises, although some countries have two main cities, as in Bolivia, Brazil, Ecuador and Honduras, while Mexico has an urban system with numerous nodes that offset the main city (Rodríguez, 2002, cited by the National Population Council of Bolivia (CONAPO) and Tuirán).

In this context, the main question is whether indigenous populations who have migrated to cities have followed the same patterns as the dominant society, and whether they therefore form urban systems similar to non-indigenous ones. The figures in table 3 suggest a negative answer to that question, at least in aggregate terms, although the two groups do have common features. 
Table 3

DISTRIBUTION OF THE URBAN POPULATION BY MAIN URBAN CENTRES, ETHNICITY AND PRIMACY INDEX OF MAIN CITY

\begin{tabular}{|c|c|c|c|c|c|c|c|c|}
\hline \multirow{2}{*}{$\begin{array}{l}\text { Country } \\
\text { Bolivia }\end{array}$} & \multirow{2}{*}{$\begin{array}{c}\text { Ethnicity } \\
\text { Indigenous }\end{array}$} & \multicolumn{3}{|c|}{ Main urban centres } & \multirow{2}{*}{$\begin{array}{l}\text { Other } \\
\text { urban } \\
\text { areas }\end{array}$} & \multicolumn{2}{|c|}{ Urban total } & \multirow[t]{2}{*}{$\begin{array}{l}\text { Primacy } \\
\text { index }^{a}\end{array}$} \\
\hline & & La Paz & Santa Cruz & Cochabamba & & & & \\
\hline & & 37.0 & 12.8 & 11.5 & 38.7 & 100.0 & 2676057 & 1.5 \\
\hline & Non-indigenous & 17.6 & 31.9 & 8.3 & 42.2 & 100.0 & 2352273 & 1.2 \\
\hline \multirow[t]{4}{*}{ Brazil } & \multirow[t]{2}{*}{ Indigenous } & São Paulo & Río de Janeiro & Salvador & & & & \\
\hline & & 8.1 & 7.8 & 6.0 & 78.1 & 100.0 & 383298 & 0.6 \\
\hline & \multirow[t]{2}{*}{ Non-indigenous } & São Paulo & Río de Janeiro & Bello Horizonte & & & & \\
\hline & & 12.4 & 8.0 & 2.9 & 76.7 & 100.0 & 136620255 & 1.1 \\
\hline \multirow[t]{4}{*}{ Chile } & \multirow[t]{2}{*}{ Indigenous } & Santiago & Temuco & Arica & & & & \\
\hline & & 39.8 & 6.4 & 5.1 & 48.8 & 100.0 & 448382 & 3.5 \\
\hline & \multirow[t]{2}{*}{ Non-indigenous } & Santiago & Valparaíso & Concepción & & & & \\
\hline & & 41.2 & 6.4 & 5.2 & 47.2 & 100.0 & 12641731 & 3.6 \\
\hline \multirow[t]{4}{*}{ Costa Rica } & \multirow[t]{2}{*}{ Indigenous } & San José & Limón & Heredia & & & & \\
\hline & & 43.3 & 12.5 & 4.4 & 39.9 & 100.0 & 13383 & 2.6 \\
\hline & \multirow[t]{2}{*}{ Non-indigenous } & San José & Heredia & Cartago & & & & \\
\hline & & 45.8 & 6.4 & 5.6 & 42.2 & 100.0 & 2180867 & 3.8 \\
\hline \multirow[t]{4}{*}{ Ecuador } & \multirow[t]{2}{*}{ Indigenous } & Quito & Guayaquil & Otavalo & & & & \\
\hline & & 27.7 & 20.3 & 4.8 & 47.3 & 100.0 & 149832 & 1.1 \\
\hline & \multirow[t]{2}{*}{ Non-indigenous } & Guayaquil & Quito & Cuenca & & & & \\
\hline & & 29.2 & 18.6 & 3.8 & 48.3 & 100.0 & 7281523 & 1.3 \\
\hline \multirow[t]{4}{*}{ Guatemala } & \multirow[t]{2}{*}{ Indigenous } & Guatemala & Quetzaltenango & Chichicastenango & & & & \\
\hline & & 10.7 & 3.9 & 3.0 & 82.4 & 100.0 & 1474868 & 1.6 \\
\hline & \multirow[t]{2}{*}{ Non-indigenous } & Guatemala & Quetzaltenango & Escuintla & & & & \\
\hline & & 49.1 & 1.7 & 2.3 & 46.9 & 100.0 & 3709967 & 12.4 \\
\hline \multirow[t]{4}{*}{ Honduras } & \multirow[t]{2}{*}{ Indigenous } & San Pedro Sula & La Ceiba & Brus Laguna & & & & \\
\hline & & 17.1 & 13.2 & 8.6 & 61.1 & 100.0 & 65760 & 0.8 \\
\hline & \multirow[t]{2}{*}{ Non-indigenous } & Tegucigalpa $^{\mathrm{b}}$ & San Pedro Sula & La Ceiba & & & & \\
\hline & & 28.4 & 17.1 & 4.0 & 50.4 & 100.0 & 2729192 & 1.4 \\
\hline \multirow[t]{4}{*}{ Mexico } & Indigenous & Mexico City & Mérida & Juchitan de Zaragoza & & & & \\
\hline & & 6.9 & 3.3 & 3.1 & 86.7 & 100.0 & 2186694 & 1.1 \\
\hline & Non-indigenous & Mexico City & Guadalajara & Monterrey & & & & \\
\hline & & 24.7 & 5.0 & 4.5 & 65.9 & 100.0 & 68408292 & 2.6 \\
\hline Panama & Indigenous & Panama City & Changuinola & Colon & & & & \\
\hline & & 59.0 & 20.3 & 6.5 & 14.2 & 100.0 & 52187 & 2.2 \\
\hline & Non-indigenous & Panama City & Colón & David & & & & \\
\hline & & 69.0 & 7.8 & 6.0 & 17.2 & 100.0 & 1712584 & 5.0 \\
\hline Paraguay & Indigenous & Fernhein & Asunción & Menno & & & & \\
\hline & & 39.2 & 18.4 & 14.7 & 27.8 & 100.0 & 8093 & 1.2 \\
\hline & Non-indigenous & Asunción & Ciudad del Este & Encarnación & & & & \\
\hline & & 54.8 & 7.6 & 2.3 & 35.3 & 100.0 & 2920344 & 5.5 \\
\hline
\end{tabular}

Source: Latin American and Caribbean Demographic Centre (CELADE) - Population Division of ECLAC, special processing of census microdatabases.

a The primacy index is the ratio of the population of the main city to the sum of the populations of the two next largest cities.

${ }^{\mathrm{b}}$ Central District municipality of the department of Francisco Morazán.

First, in six of the 10 countries considered, urban indigenous people are mainly located in the largest urban centre. This is not the case in the other four countries. The cities with the largest indigenous populations are Quito in Ecuador; San Pedro Sula in Honduras; and Ferhein (Boquerón) 
in Paraguay. In Bolivia, where the population is mainly indigenous, non-indigenous population lives mainly in Santa Cruz, which is not the largest city. Bolivia is the only country where the three main cities of settlement are the same for the indigenous and non-indigenous population (albeit in a different order and with dissimilar concentration patterns).

One distinctive aspect of indigenous urban systems is the lesser degree of concentration in the main city, compared with non-indigenous systems, as reflected by the primacy index. The exceptions are Bolivia, where the index is higher for the indigenous population, and Chile and Ecuador, where the figures are lower for indigenous people but nonetheless fairly similar to nonindigenous figures (with a high concentration in the case of Chile). The distribution of the indigenous population shown in table 3 suggests that the urban segment is fairly complex, in the sense that there seem to be a number of nodes, as is the case throughout Mexico. This is related to the specific cultural characteristics of each indigenous people, which are associated with different levels of mobility in terms of the urban centres of destination. They seem to favour those centres that are closest to their communities of origin, as is the case with the Ngöbe people of Panama, who migrate mainly to the neighbouring provinces of Bocas del Toro and Chiriquí, and the Kunas, who move mostly to Panama City.

The previous point is reinforced by another shared characteristic revealed by the figures: indigenous persons living in urban areas tend to be concentrated in cities located in major administrative divisions that have a large indigenous presence and are located in or near their ancestral areas. Examples include Salvador (Bahía, Brazil); Temuco and Arica (in La Araucanía and Tarapacá, Chile); Limón (Costa Rica); Otavalo (Imbabura, Ecuador); Chichicastenango (Quiché, Guatemala); Brus Laguna (Gracias a Dios, Honduras); Mérida and Juchitan de Zaragoza (Yucatán and Oaxaca,, Mexico); Changuinola (Bocas del Toro, Panama); and Fernhein and Menno (Boquerón, Paraguay). Broadly speaking, these results point to at least two migratory patterns: one towards the large metropolis and another towards an urban centre near ancestral indigenous territories. ${ }^{19}$ These patterns can be observed in internal migration in Bolivia, Ecuador and Panama (IDB/ECLAC, 2005a-d). The characteristics of these flows should be investigated further, using the criteria described above, and analysing the factors that contribute to the choice of a particular urban destination and the extent to which these patterns affect ties (or loss thereof) between migrants and their communities of origin. This should then be extended to an analysis by people of origin.

\subsubsection{Distribution of indigenous population within the system of cities}

Public policy makers are concerned by indigenous settlements in urban contexts, in particular as regards the implications for host communities; the living conditions and possible cultural and social changes that the indigenous populations experience in cities and the transformations that cities undergo overall as a result of the growing ethnic diversity.

As far as living conditions are concerned, residing in urban areas affords, a priori, greater access to State services. Socio-economic indicators continue, however, to be more unfavourable in the case of indigenous persons. It has been argued that indigenous people usually settle in marginal areas and that this contributes to the reproduction and aggravation of the inequity inherent in the lack of opportunities and problems of cultural accessibility of State programmes and services. From an Anglo-Saxon perspective, this affirmation implies some degree of residential segregation, that is, the geographical convergence of groups of the same social - in this instance, ethnic - condition, either through concentration in a few areas, or through the formation of socially homogeneous areas (Rodríguez, 2001). In the first case, segregation arises from the concentration of a social group in a given area of a territory, irrespective of whether other social groups already live in that territory; in the second case, the point to note is the absence of interaction between social groups that live in common areas, even though the social group that fails to integrate may reside in a different part of the city.

19 In the case of Bolivia and Mexico, it should be borne in mind that there are indigenous peoples whose original territories are located in cities. 
Studies on spatial segregation usually highlight the negative aspects of this phenomenon, namely exclusion and reproduction of poverty. Nevertheless, the positive aspects are now being recognized, that is the construction of facilities with persons that have common interests and lifestyles, as may be the case with indigenous peoples. Segregation may also fit in with strategies and opportunities typical of family networks. Bearing in mind these two perspectives, a rights-based approach should be used to determine whether there are unequal opportunities in terms of access to the goods and services that the city has to offer. A response to this question is beyond the scope of this document; suffice it to say that the census has great potential to contribute to this line of enquiry.

Quantitative measurements frequently used in studies on residential segregation are presented below, although, in this case, the term segregation does not necessarily have negative connotations; rather, the point is to determine whether indigenous populations are distributed unevenly within cities.

The Duncan dissimilarity index presented in table 4 indicates that the distribution of the indigenous population by spatial units of the main urban agglomerations differs from that of the non-indigenous population, albeit with varying intensity in different countries. ${ }^{20}$ Results for Mexico City, Santiago (Chile), São Paulo (Brazil), and Guatemala City reveal low levels of segregation; in theory, it would be wrong to speak of a "racial ghetto" in terms of the urban space under consideration. The figures for La Paz (Bolivia), San José (Costa Rica), Quito (Ecuador) and Panama City show an intermediate level of spatial segmentation; and in the cases of San Pedro Sula (Honduras) and Asunción (Paraguay), the figures indicate a high degree of segregation.

Table 4

DUNCAN DISSIMILARITY INDEX APPLIED TO CITIES AND GINI CONCENTRATION INDEX BY INDIGENOUS AND NON-INDIGENOUS POPULATION, 2000 ROUND OF CENSUSES

\begin{tabular}{l|c|c|c}
\hline \multirow{2}{*}{ Cities } & \multirow{2}{*}{ Duncan dissimilarity index } & \multicolumn{2}{c}{ Gini index } \\
\cline { 3 - 4 } & & Indigenous & Non-indigenous \\
\hline Mexico City (Mexico) & 15.4 & 86.2 & 82.4 \\
São Paulo (Brazil) & 20.0 & 55.9 & 46.4 \\
Santiago (Chile) & 20.4 & 49.5 & 35.8 \\
Guatemala City (Guatemala) & 26.4 & 85.0 & 79.3 \\
La Paz (Bolivia) & 30.2 & 15.2 & 31.1 \\
San José, Costa Rica & 33.9 & 63.7 & 38.6 \\
Quito, Ecuador & 35.1 & 47.0 & 7.5 \\
Panama City, Panama & 36.4 & 56.8 & 34.9 \\
San Pedro Sula, Honduras & 60.0 & 89.4 & 62.1 \\
Asunción, Paraguay & 82.7 & 96.9 & 39.1 \\
\hline
\end{tabular}

Source: Latin American and Caribbean Demographic Centre (CELADE) - Population Division of ECLAC, special processing of census microdatabases.

The Duncan dissimilarity index measures how dissimilar the patterns of distribution of indigenous and non-indigenous populations are within urban centres but reveals nothing on the nature of this distribution; thus, the Gini concentration index may be used to provide a complementary analysis (see table 4). This index also varies from 0 to 1 (or from 0 to 100 if it is

20 Comparisons between countries should be approached with caution, since administrative divisions within cities are based on different scales and their average sizes vary considerably: Mexico City and Asunción have localities; São Paulo, Santiago and San José, districts; Guatemala City, populated areas; La Paz and Quito, census areas; Panama City, "corregimientos"; and San Pedro Sula, neighbourhoods. 
multiplied by this constant); the closer to 1 , the higher the concentration of the population in given territorial units of the city. The results show that the degree of concentration of the indigenous population within the city is systematically higher than that of the non-indigenous population, except in the case of La Paz. ${ }^{21}$ Asunción, San Pedro Sula, Guatemala City and Mexico City display the highest levels of concentration of the indigenous population, although in the last two countries, the readings are also high for the non-indigenous population. Quito, Asunción, Panama City and San José have the highest relative differences between the degree of concentration of indigenous and non-indigenous persons.

Maps 1 to 4 give further insight into the spatial distribution of the indigenous population in three urban agglomerations: Santiago, San José and Panama City. The maps illustrate the last decile, that is, the $10 \%$ of districts with the largest indigenous population (or the $10 \%$ with the highest proportion of indigenous people). These units account for 34\% of the indigenous population living in Santiago; $56 \%$ of those living in San José; and 46\% of those living in Panama City. This corroborates findings relating to territorial concentration. The maps show which spatial units have the largest indigenous settlements. In addition, it will be noted that, generally speaking, there is a relationship between the absolute size of the indigenous population and the percentage this population represents of the overall population in each district. Another finding revealed by the figure is that while there are signs of residential segregation, the districts or corregimientos are by no means ethnically homogeneous; indigenous people account for less than $10 \%$ in each unit except in the corregimiento of Veracruz (Panama City), where they account for $23 \%$. Clearly, on a smaller scale, these results could be different (for example if the information is processed for blocks within a district).

Lastly, the census may be used to construct geographically disaggregated indicators of living conditions so as to characterize the main areas of settlement of urban indigenous population. This would make it possible to refine the analysis in terms of residential segmentation based on socioeconomic factors. In some countries, it is also possible to consider different social groups, including diverse indigenous peoples, that live alongside each other.

A rapid analysis of the available databases suggests that in the case of San José and Panama City, the areas with the highest proportion of indigenous population are the poorest areas. In the case of Santiago, once again, indigenous population tend to settle in districts where poverty levels are above the average for the city, although not necessarily the highest.

21 This result is hardly surprising since the indigenous population is in the majority in La Paz and it is therefore the non-indigenous segments that are spatially segregated. Santa Cruz, on the other hand, displays a higher territorial concentration of the indigenous population compared with the non-indigenous population (the Gini Index yields results of 17.6 and 10.5, respectively). 


\section{GREATER SANTIAGO: INDIGENOUS POPULATION BY DISTRICT, LAST DECILE}

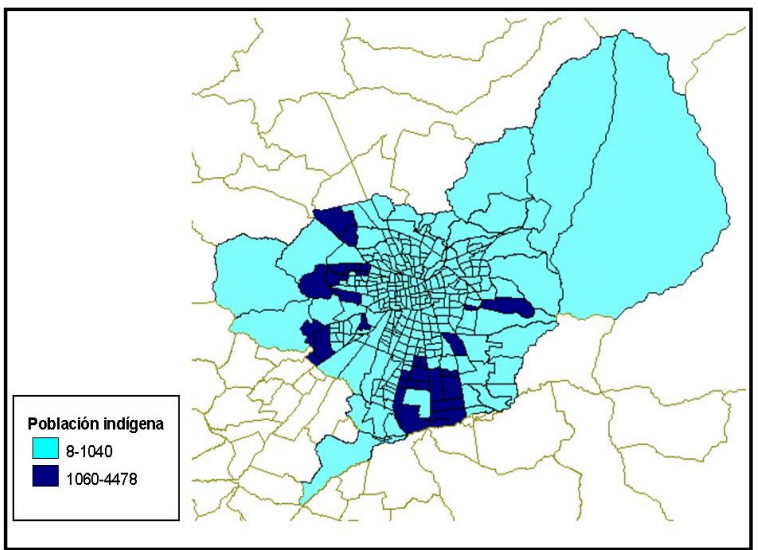

Map 3

GREATER SAN JOSÉ: INDIGENOUS POPULATION AND PERCENTAGE BY DISTRICT, LAST DECILE

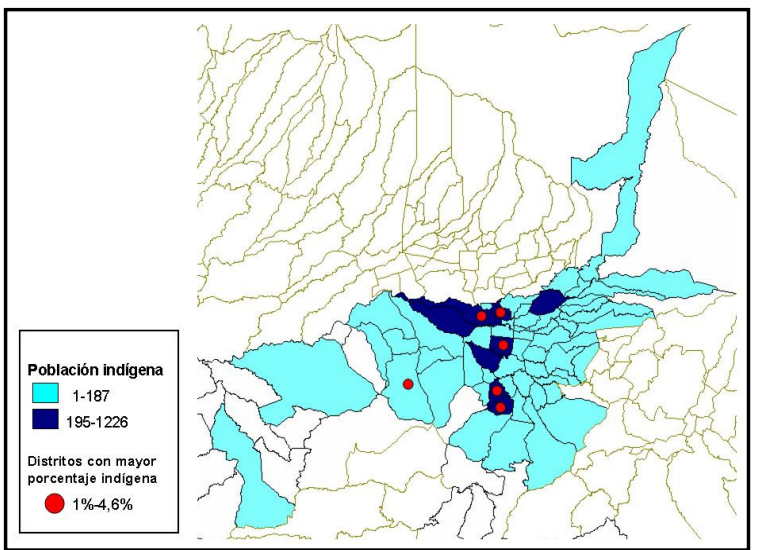

Map 2

GREATER SANTIAGO: PERCENTAGE OF INDIGENOUS POPULATION BY DISTRICT, LAST DECILE

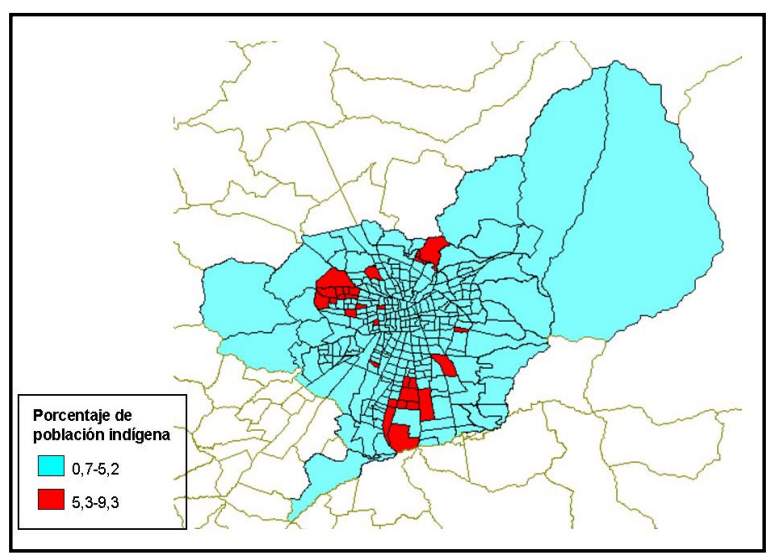

GREATER PANAMÁ: INDIGENOUS POPULATION AND PERCENTAGE BY DISTRICT, LAST DECILE

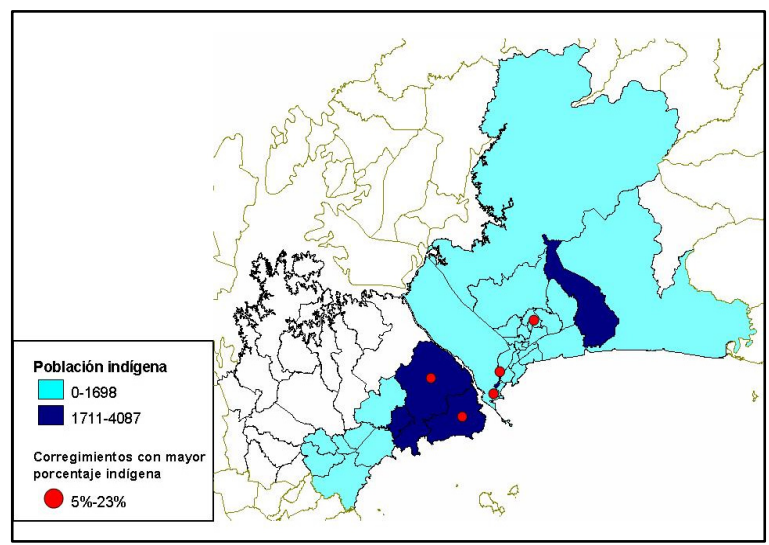

Source: Latin American and Caribbean Demographic Centre (CELADE) - Population Division of ECLAC, special processing of census microdatabases.

\section{Closing reflections}

This overview - albeit incomplete - of the territorial location of indigenous peoples in Latin America has been made possible by the inclusion of a question on ethnic identification in population censuses. While determining the number of indigenous persons is still problematic, the census is a useful tool for increasing the statistical visibility of indigenous peoples, and hence for contributing to the process of building a social citizenry.

The processed information reveals that the main indigenous settlements are situated in areas associated with the ancestral -predominantly rural- lands of these peoples, reflecting their indissoluble attachment of to their territory. However, also noteworthy is the significant percentage of urban indigenous people in some countries of the region, as well as the wide diversity of situations depending on the indigenous group. This demonstrates the importance of drawing up public policies that take into consideration the territorial context. 
It is interesting to note that the territorial distribution of urban indigenous people differs from the trend associated with the rest of the population, insofar as the former tend to settle in urban centres close to their home territory rather than in the big metropolises. Nevertheless, within cities, high concentrations of indigenous population are typically found in geographical areas that have higher than average poverty levels. This segmentation is probably linked to indigenous family networks and cultural affinity; the other side of the coin, however, is exclusion and the resulting unequal access to the goods and services provided by the State. Thus, the new challenges facing public policy-makers is the need to incorporate a perspective based on the rights of indigenous peoples and to recognize the pluriculturalism now evident in Latin American cities.

\section{Bibliography}

Alwyn, José (2002), "El derecho de los pueblos indígenas a la tierra y al territorio en América Latina: antecedentes históricos y tendencias actuales", document presented at the Meeting of the Working Group on Chapter V of the proposed Declaration with special focus on "Traditional forms of ownership and cultural survival, rights to land and territories", Washington, D.C., 7-8 November.

Bartolomé, Miguel Alberto (1997), Gente de costumbre, gente de razón, Mexico City, Siglo XXI Editores/Instituto Nacional Indigenista.

Bello, Alvaro (2004), "Etnicidad y ciudadanía en América Latina. La acción colectiva de los pueblos indígenas" Libros de la CEPAL No 79 (LC/G.2230-P), Santiago, Chile, October. United Nations Publication, Sales N ${ }^{\circ}$ S.04.II.G.113.

Camus, Manuela (2002), Ser indigena en Ciudad de Guatemala, Guatemala, Latin American Faculty of Social Sciences (FLACSO).

CODENPE (Consejo de Desarrollo de las Nacionalidades y Pueblos del Ecuador) (2001), "Sistema de Indicadores de las Nacionales y Pueblos del Ecuador (SIDENPE)", Quito, Office of the President.

Daes, Erica-Irene (2001), Indigenous peoples and their relationship to land (E/CN.4/Sub.2/2001/21), New York, Commission on Human Rights, 11 June.

Del Popolo, Fabiana and Ana María Oyarce, (2005), “América Latina, población indígena: perfil sociodemográfico en el marco de la Conferencia Internacional sobre la Población y el Desarrollo y de las metas del Milenio", Notas de Población No 79 (LC/G.2284-P), Santiago, Chile, June. United Nations Publication, Sales No S.05.II.G.141.

Delaunay, Daniel (2003), "Identidades demográficas del poblamiento y de los pueblos indígenas: un análisis contextual", Las dinámicas de la población indígena. Cuestiones y debates actuales en México, Mexico City, Centre for Research and Higher Learning in Social Anthropology/Research Institute for Development (CIESAS/IRD).

Deruyttere, Anne (1997), "Indigenous peoples and sustainable development: the role of the Inter-American Development Bank", IDB Forum of the Americas $\mathrm{N}^{\circ}$ IND97-101, Washington, D.C.

ECLAC (Economic Commission for Latin America and the Caribbean) (2006), Shaping the Future of Social Protection: Access, Financing and Solidarity (LC/G.2294(SES.31/3)), Santiago, Chile, March.

(2005), "Latin America: urbanization and urban population trends", Demographic Bulletin N 75 (LC/G 2268-P), Santiago, Chile, Latin American and Caribbean Demographic Centre (CELADE)Population Division of ECLAC, January. United Nations Publication, Sales $\mathrm{N}^{\mathrm{o}}$ E/S.05.II.G.3.

Evelis Andrade, Luis (2006). "Los sistemas de información sociodemográfica al servicio del "desarrollo con indentidad"”, Pueblos indigenas y afrodescendientes de América Latina y el Caribe: información sociodemográfica para políticas y programas, Project documents (LC/W.72), Santiago, Chile, April. Economic Commission for Latin America and the Caribbean (ECLAC).

Gamboa, Juan Carlos (2006), "Pueblos indígenas y ordenamiento territorial o la urgente necesidad de ordenar el pensamiento" [online] http://www.ucm.es/info/cecal/encuetr/areas/antropol/1a/ gamboa.

González Chévez, Lilian (2001), “Anclajes y transformaciones culturales de un pueblo Náhuatl en transición, el caso de Temalac", Guerrero, Mexico City, Department of Anthropology, National Autonomous University of Mexico.

IDB/ECLAC (Inter-American Development Bank/Economic Commission for Latin America and the Caribbean) (2005a), "Los pueblos indígenas de Bolivia: diagnóstico sociodemográfico a partir del censo del 2001”, Project documents, No 24 (LC/W.24), Santiago, Chile. 
(2005b), "Población indígena y afroecuatoriana en Ecuador: diagnóstico sociodemográfico a partir del censo de 2001", Project documents, N 16 (LC/W.16), Santiago, Chile.

(2005c), "Los pueblos indígenas de Panamá: diagnóstico sociodemográfico a partir del censo del 2000", Project documents, No 20 (LC/W.20), Santiago, Chile. April.

(2005d), Atlas sociodemográfico de los pueblos indígenas de Panamá (LC/R.2124), Santiago, Chile,

IWGIA (International Work Group for Indigenous Affairs) (2006), The Indigenous World 2006, Copenhagen.

ONIC (Organización Nacional Indígena de Colombia) (2002), "Caracterización general del desplazamiento indígena en Colombia”, El desplazamiento indígena en Colombia. Caracterización y estrategias para su atención y prevención en áreas críticas, Bogotá, D.C.

Pagliaro, Heloísa, Marta Azevedo and Ricardo Ventura Santos (2005), "Demografia dos povos indígenas no Brasil: um panorama crítico", Demografía dos povos indígenas no Brasil, Rio de Janeiro, Editorial Fiocruz.

Pérez Brignoli, Héctor (2005), “La dinámica demográfica de las poblaciones indígenas del trópico húmedo en América Central (censos 2000)", document presented at the twenty-fifth International Conference of the International Union for the Scientific Study of Population (IUSSP), Tours, 18 - 23 July.

Quesnel, André (2006), "Dinámicas demo-sociales de la población indígena y afrodescendiente en América Latina", Pueblos indígenas y afrodescendientes de América Latina y el Caribe: información sociodemográfica para políticas y programas, Project documents, No 72 (LC/W.72), Santiago, Chile, Economic Commission for Latin America and the Caribbean (ECLAC).

Renshaw, Jonathan and Natalia Wray (2004), "Indicadores de pobreza indígena" [online] Inter-American Development Bank (IDB) http://www.iadb.org/publications/search.cfm?language=English\& topics=IS-ing.

Rodríguez Vignoli, Jorge (2002), "Distribución territorial de la población de América Latina y el Caribe: tendencias, interpretaciones y desafíos para las políticas públicas", serie Población y Desarrollo N 32 (LC/L.1831-P/E), Santiago, Chile, Economic Commission for Latin America and the Caribbean (ECLAC), December. United Nations publication, Sales N S.02.II.G.137.

(2001), "Segregación residencial socioeconómica: ¿qué es?, ¿cómo se mide?, ¿qué está pasando?, ¿importa?”, serie Población y Desarrollo No 16 (LC/L.1576-P/E), Santiago, Chile, Economic Commission for Latin America and the Caribbean (ECLAC). United Nations publication, Sales N ${ }^{\circ}$ S.01.II.G.54.

Serrano, Enrique, Arnulfo Embriz and Patricia Fernández Ham (coords.) (2002), Indicadores socioeconómicos de los pueblos indígenas de México, National Institute of Indigenous Affairs/United Nations Development Programme/National Population Council (NIIA/UNDP/CONAPO).

Solano, Elizabeth (2004), "La población indígena en Costa Rica según el censo 2000”, Costa Rica a la luz del Censo del 2000, San José, Centro Centroamericano de Población/Universidad de Costa Rica, Imprenta Nacional.

Toledo Llancaqueo, Victor (2005), "Políticas indígenas y derechos territoriales en América Latina 1990-2004 ¿Las fronteras indígenas de la globalización?”, Pueblos indígenas y democracia en América Latina, Buenos Aires, Latin American Social Sciences Council (CLACSO).

UNDP (United Nations Development Programme) (2002), Informe nacional de desarrollo humano Panamá 2002.

United Nations (2006), Report of the Special Rapporteur on the Situation of Human Rights and Fundamental Freedoms of Indigenous People, Mr. Rodolfo Stavenhagen (E/CN.4/2006/78), New York, February.

Valenzuela, Rodrigo (2004), "Inequidad, ciudadanía y pueblos indígenas en Bolivia”, serie Políticas Sociales No 83 (LC/L.2089-P), Santiago, Chile, Economic Commission for Latin America and the Caribbean (ECLAC), March. United Nations publication, Sales No S.04.II.G.27.

Ventura Santos, Ricardo, Nancy Flowers and Carlos Coimbra Jr. (2005), "Demografía, epidemias e organização social: os Xavánte de Pimental Barbosa (Etéñitépa), Mato Grosso", Demografía dos povos indígenas no Brasil, Rio de Janeiro, Editorial Fiocruz. 


\section{Internal migration of indigenous peoples: systematizing and analysing relevant census information in order to update perspectives, increase knowledge and improve interventions}

Jorge Rodríguez ${ }^{22}$

\section{Purpose of study and object of analysis}

In view of the limited information available on the internal migration of indigenous peoples, the United Nations Permanent Forum on Indigenous Issues (UNPFII) suggested that workshops should be held to correct the lack of data. ${ }^{23}$ One of the established aims of these workshops was "to highlight and address the lack of reliable data on the issue and to promote the systematic collection of data (of both quantitative and

22 Latin American and Caribbean Demographic Center (CELADE) - ECLAC Population Division. The author acknowledges the valuable comments of Fabiana Del Popolo to a draft of this document and thanks the support of Mario Acuña in data processing. Of course, the author is responsible of the final contents of the paper.

23 Report of an Expert Workshop on Indigenous Peoples and Migration: Challenges and Opportunities, Geneva: 6-7 April 2006 E/C.19/2006/CRP.5, 5 May 2006 (www.un.org/esa/socdev/unpfii/documents/ 5session_crp5_migration.doc). 
qualitative nature) by relevant United Nations and other intergovernmental entities, Governments, $N G O s$, indigenous organizations, and academia". Precisely with a view to increasing the amount of knowledge and data on the subject, this document attempts to illustrate the potential of censuses as a basic source of information on indigenous peoples and their migratory patterns. This study uses census datasets to produce, systematize and provide comparative analyses on evidence of indigenous migration, especially in terms of movement between urban and rural areas. The present paper will illustrate this approach by processing ${ }^{24} 10$ census databases containing microdata from the 2000 round of censuses in the region and analysing the results. The 10 censuses were selected because they included questions, in one form or another, on ethnicity. ${ }^{25}$

\section{Research questions}

In the light of the applied purpose of the study and the descriptive analysis to be carried out, the document will be divided up into sections based on key questions concerning migratory intensity, patterns and profiles among indigenous peoples and how they differ from those of non-indigenous groups. These questions will guide how results are produced and analysed. The analysis will be two-fold. First, results will be compared with existing perspectives and theories. Second, the data will be used to carry out comparative analyses between ethnic groups and between countries. These key questions are as follows:

a) Are indigenous people less likely to migrate at the levels of major and minor administrative divisions?

b) After controlling for exogenous factors (such as age and education), is there any change in the propensity of indigenous people to migrate at the levels of major and minor administrative divisions?

c) Where do indigenous people migrate to at the level of major administrative divisions and between urban and rural areas?

d) What are the characteristics of indigenous people who migrate at the levels of major and minor administrative divisions and between urban and rural areas?

e) How do indigenous people move around in relation to selected cities?

f) Are indigenous people more likely to return?

g) Is rural to urban migration among indigenous people associated with improved living conditions? The combination of these four propositions (assumptions) is what makes the desired system and routes to it so complex.

24 Using the System for the Retrieval of Census Data for Small Areas by Microcomputer (Redatam) developed by the Latin American and Caribbean Demographic Centre (CELADE) - Population Division of ECLAC. For more information, see www.eclac.cl/redatam.

25 For more information, visit the section of the CELADE website given over to this subject: www.cepal.org/celade/miginter and the database on internal migration in Latin America and the Caribbean (MIALC) (http://www.eclac.cl/migracion/migracion\%5Finterna/). 


\section{Migratory intensity, patterns and profiles among indigenous peoples, and differences in relation to non-indigenous groups}

\subsection{Conceptual definitions and basic methodology}

Migration within countries takes various forms, the most well known being movement between urban and rural areas. This gives rise to the following four conventional categories: urban $\rightarrow$ urban; rural $\rightarrow$ urban; urban $\rightarrow$ rural; rural $\rightarrow$ rural. However, there are many other ways of classifying migratory movement (Villa, 1991; Welti, 1997; Rodríguez, 2004). This study considers two other types: migration between major administrative divisions and migration between minor administrative divisions, which will enable more detailed analyses to be carried out into migratory intensity and patterns of indigenous peoples and what is specific to their patterns as opposed to those of non-indigenous groups. ${ }^{26}$ Furthermore, estimates will be made on the migratory exchange between selected cities (based on population numbers) and the rest of the country, with a view to building up a picture of indigenous migration to and from those urban centres. In terms of migrant profiles, basic characteristics such as age, sex and education will be examined to see whether migrants are representative of indigenous people or whether migration selectivity makes them a biased sample.

\subsection{Conceptual background}

Belonging to an indigenous people has often been considered a factor in migration selectivity. This factor has usually been assumed to act by systematically reducing the propensity to migrate. This is because belonging to an indigenous group supposedly implies: (a) valuing the ethnic community and its preservation as a political, economic and cultural unit; (b) greater attachment to the land as ancestral territory; (c) a predominance of traditional cultural guidelines and rules that are averse to change (including changes of residence); and (d) social sanctions associated with abandoning the land of origin, thereby discouraging out-migration. However, there are other interpretations. First, the poverty affecting indigenous people and their territories is a powerful push factor (Rodríguez, 2004). Second, indigenous peoples are particularly vulnerable to forced displacement. Third, in recent decades, economic reforms have badly affected indigenous peoples and their territories, thereby encouraging out-migration (Bello, 2004). Fourth, indigenous peoples have always moved across and beyond their territories, and may therefore be more likely to have a tradition of migration. In any event, such migration would be governed by ancestral cultural rules that could not necessarily be explained by modern social dynamics.

The idea that indigenous migration is basically due to push factors has also given rise to some critical visions. ${ }^{27}$ At the Expert Workshop on Indigenous Peoples and Migration: Challenges and Opportunities organized by UNPFII in Geneva in April 2006, many participants stated that: "because of the attachment of indigenous peoples to their land, their migration was often forced, rather than voluntary. As a result, the migration of indigenous peoples is often associated with conflict and the loss of rights" (UNFPII, 2006, par. 15). This critical vision stands in sharp contrast to a more optimistic view, which was also expressed at the same workshop: "Whether migration is

26 The source has two limitations that affect the analysis, First, the census captures migration (namely one or at the most two changes of residence, which means some changes are lost) and not mobility. This is a weakness given that current research suggests that indigenous peoples move regularly rather than "migrate" as such. The second limitation is that divisions correspond to official political and administrative areas, rather than those of the indigenous peoples themselves. Both limitations may affect the figures presented.

27 Bello (2004, p. 56) considers this critical vision part of the past and not in keeping with the current situation in terms of indigenous migration. He says that, historically, indigenous migration to the city has been seen as synonymous with cultural death, assimilation and discrimination. 
forced or voluntary, participants recognized that a number of opportunities that do not exist in indigenous communities may become available to those who migrate" (UNFPII, 2006, par. 21). In practice, both phenomena (risk and opportunity) are part of indigenous (or indeed any) migration. Rather than identifying exclusively with one side of the argument, it is therefore more important to establish which aspect prevails in specific cases.

Internal migration of indigenous populations has often been classified as one of two major subtypes of migration: (i) permanent migration from the countryside to the city, or, (ii) (usually seasonal) migration between rural areas (Rodríguez, 2004). In the first case, indigenous migration to the city is a variant of the rural-urban flows of unskilled workers, landless peasants and small agricultural landowners seeking better opportunities in the city (or pushed out of their rural area of origin). One specific characteristic of these flows linked to roots and ethnic-cultural identity is that rural-urban indigenous migration seems to be associated with a greater possibility of subsequent return migration. This was raised at the above-mentioned workshop: "The often involuntary nature of most indigenous peoples' migration means that when opportunities to return arise, many migrants seek to go back" (UNFPII, 2006, par. 17). In the case of rural-rural indigenous migration, this seems to involve territorial movements linked to opportunities of temporary agricultural work in areas surrounding the communities of origin (during harvest, for instance) or temporary migration to assist relatives or other members of the communities in primary seasonal (mainly agricultural) activities or itinerant (mainly pastoral) activities.

Recent research in the region has provided fresh insight into indigenous migration. In some countries, ${ }^{28}$ a wide range of studies provides an overview not only of indigenous migration in general (and its comparisons with non-indigenous migration) but of migration in terms of specific indigenous groups. Although analysis has clearly been enriched by this, most of the research is ethnographic, which means its findings cannot be generalized. What is more, there has been no comparative quantitative research into migration among indigenous peoples of different countries in the region. ${ }^{29}$ In this sense, the findings of this document can therefore be considered ground-breaking.

The interpretations of internal indigenous migration emerging from this new wave of research sometimes change conventionally held viewpoints. This is largely because the studies recognize the notions of both identity and diversity, and consider the opportunities as well as the risks involved in migration. In terms of the counterpoint between identity and diversity, the former is acknowledged as a unifying factor (especially if it is general and in opposition to non-indigenous identity), while the latter differentiates, either by revealing variety within indigenous peoples or by highlighting phenomena with changing, superimposed and hybrid identities. Diversity tangibly manifests itself in migration, as different indigenous peoples (or different communities of the same indigenous group in various locations) develop their own migratory strategies and circuits. The Mexican situation has been described in detail in a document comparing the migration dynamics of several peoples (INI, 2000). Diversity is also relevant to the forms of migration, which can no longer be exclusively classified as one of the two above-mentioned categories. As pointed out in the study carried out in Mexico, migration flows have reoriented themselves to other cities following the consolidation of old areas and/or the appearance of new areas of development. This reorientation is basically a diversification of displacement patterns, which have branched out from the traditional countryside-to-city migration to include migration from the countryside to medium

28 In Mexico, in particular, a study was carried out by the National Commission for the Development of Indigenous Peoples. For more information, go to: http://cdi.gob.mx/index.php?id_seccion=1809.

29 There is considerable comparative material in the IDB/ECLAC project Indigenous and Afrodescendent Population in Censuses (ECLAC, Social Panorama of Latin America 2006, forthcoming; CELADEPopulation Division of ECLAC, 2006; IDB/ECLAC 2005a, 2005b, 2005c; Del Popolo and Oyarce, 2005), and some previous research has generated comparative analyses (Murdock, 1967; Peyser and Chackiel, 1994; Pérez Brignoli, 2005); however, these studies have not tended to include migration. Bello (2004) examines the subject in more detail but does not provide new or specific empirical information. 
cities, rural-rural migration and migration from rural areas to northern border areas (http://cdi.gob.mx/index.php?id_seccion=1822) (Spanish only).

Still on the subject of diversity, indigenous peoples are not immune to increasing sociocultural heterogeneity, which in today's globalized world manifests itself as hybridization, cultural diaspora and a "deterritorialization" of identities (Bastos, 1999). ${ }^{30}$ This has at least two implications for the migratory processes of ethnic groups (Rodríguez, 2004): (a) a less problematic process of assimilation for indigenous migrants at destination (particularly in urban areas) - an issue which has been the subject of much research in recent decades; and (b) among indigenous groups, return migration becomes less significant and likely. These factors will probably help to do away with the idea of a strong attachment to the land, a characteristic traditionally associated with indigenous groups and which formed the basis for claims that indigenous people migrated less than non-indigenous groups.

The stumbling block for optimistic interpretations of the assimilation of indigenous migrants is the issue of ethnic ghettos in metropolitan areas. These ghettos reflect extreme cultural and spatial segregation of indigenous populations and generate a relocation or "reterritorialization" (as Bastos puts it) of ethnic identities. According to Bastos, the spatial dispersion of ethnic groups resulting from internal migration in the region is somewhat limited by the fact that indigenous peoples appropriate new areas of their destinations (by settling in certain locations). By establishing multiple and complex connections with their communities of origin and the indigenous migrant community at destination, they transcend the concept of space as a closed and exclusive entity and turn it into a symbolically inclusive category (Bastos, 1999). This is backed up by Bello (2004, p. 59), who states that migration involves adopting new ways of appropriating space.

The concentrated location pattern of indigenous people in cities is a good example of the need to take account of the diverse factors that may underlie a social phenomenon, and also of the variety of consequences it might generate. The driving forces behind this pattern of location, according to one interpretation, are economic exclusion (low incomes force indigenous people to live in the poorest and most disadvantaged areas of town) and cultural segregation (whereby rejection - of indigenous people in particular - acts as a barrier to their settling in non-indigenous areas). Other interpretations claim that the patterns are attributable to ethnic affinity and networkbased assistance. The latter interpretation certainly puts a positive slant on the concentrated location pattern, although not necessarily in net terms. In terms of consequences, although it may seem paradoxical, this pattern has even prompted some authors to recognize that migration of indigenous peoples to cities may even strengthen their culture. ${ }^{31}$

In summary, there is no consensus on the indigenous propensity to migrate, the nature, origin and destination of their migratory flows, the characteristics of indigenous migrants or the adaptation process at destination (especially in urban areas). What follows is an attempt to come up with some empirical answers to specific questions associated with those doubts.

30 Indigenous peoples themselves also contribute to this sociocultural diversification, as they bring their own tradition of symbols to destination locations or other cultures.

31 "However, the evidence shows that while in many cases urban transplantation is destructive of indigenous culture, in other circumstances their cultures may be preserved and even reinforced as they gather in particular parts of cities, and additional income allows them to form new cultural patterns that reinforce cultural cohesion" (ILO, 2006, http://www.un.org/esa/socdev/unpfii/documents/workshop_ipm_ilo.pdf). 


\subsection{Evidence and analysis}

\subsubsection{Are indigenous people less likely to migrate at the levels of major and minor administrative divisions?}

Table 1 shows that, in most countries, indigenous people were less likely to migrate (in the five years prior to the census). However, migration between major administrative divisions is more diverse: in at least two countries (Chile and Panama), indigenous people were more likely to migrate than non-indigenous people. In two other countries (Bolivia and Costa Rica), the differences between indigenous and non-indigenous people were slight. This is not the case for migration between minor administrative divisions: in all countries analysed, indigenous people were less likely to migrate than non-indigenous groups. This conclusion is based on recent migration experiences (five years before the census), which means that it is not necessarily representative of migration history over the last few decades. In this sense, the results presented later in the document on absolute migration (i.e. in relation to place of birth) will provide a more complete picture of the differences in migratory intensity between indigenous and non-indigenous people.

Table 1

PERCENTAGE OF MIGRANTS BETWEEN MAJOR ADMINISTRATIVE DIVISIONS AND MINOR ADMINISTRATIVE DIVISIONS IN THE FIVE YEARS PRIOR TO THE CENSUS, INDIGENOUS AND NON-INDIGENOUS PEOPLE, TOTAL FIGURES AND DIFFERENCES (IN PERCENTAGE POINTS) BETWEEN THE TWO GROUPS

\begin{tabular}{l|c|c|c|r|r|r|r|r}
\hline \multirow{2}{*}{$\begin{array}{c}\text { Country and } \\
\text { census year }\end{array}$} & \multicolumn{3}{|c|}{$\begin{array}{c}\text { Recent migration between major } \\
\text { administrative divisions }\end{array}$} & \multicolumn{3}{c}{$\begin{array}{c}\text { Recent migration between minor } \\
\text { administrative divisions }\end{array}$} \\
\cline { 2 - 9 } & Indigenous & $\begin{array}{c}\text { Non- } \\
\text { indigenous }\end{array}$ & Total & Difference & Indigenous & $\begin{array}{c}\text { Non- } \\
\text { indigenous }\end{array}$ & Total & Difference \\
\hline Bolivia, 2001 & 5.4 & 6.1 & 5.7 & -0.6 & 9.4 & 9.6 & 9.5 & -0.2 \\
Brazil, 2000 & 3.1 & 3.4 & 3.4 & -0.3 & \multicolumn{2}{|c|}{ N.D. } \\
Chile, 2002 & 6.3 & 5.8 & 5.8 & 0.5 & 15.8 & 16.0 & 16.0 & -0.2 \\
Costa Rica, 2000 & 4.8 & 5.6 & 5.6 & -0.8 & 8.4 & 10.9 & 10.8 & -2.5 \\
Ecuador, 2001 & 4.0 & 5.3 & 5.2 & -1.3 & 6.4 & 8.8 & 8.6 & -2.4 \\
Guatemala, 2002 & 2.2 & 3.4 & 2.9 & -1.2 & 5.6 & 7.9 & 7.0 & -2.4 \\
Mexico, 2000 & 2.9 & 4.6 & 4.5 & -1.6 & 4.4 & 7.1 & 7.0 & -2.8 \\
Honduras, 2000 & 2.1 & 4.4 & 4.2 & -2.3 & 3.2 & 6.3 & 6.1 & -3.1 \\
Panama, 2000 & 8.3 & 6.1 & 6.3 & 2.2 & 11.6 & 12.7 & 12.6 & -1.0 \\
Paraguay, 2002 & 3.3 & 7.7 & 7.6 & -4.4 & 7.2 & 11.6 & 11.5 & -4.5 \\
\hline
\end{tabular}

Source: Latin American and Caribbean Demographic Centre (CELADE) - Population Division of ECLAC, special processing of census microdatabases.

The figures in table 1 confirm the prevailing hypothesis that indigenous people are less likely to migrate. However, the fact that this difference appears more consistent for minor administrative divisions is counterintuitive, as the literature states that such divisions have a great potential for indigenous migration, which should be reflected in a higher relative frequency of migrants between them (especially divisions with a population that is totally or mostly indigenous). The answer may lie in the fact that a significant proportion of migration between minor administrative divisions is intra-metropolitan migration (for residential rather than employment reasons). Indigenous people are underrepresented in large metropolitan areas and therefore less involved in intra-metropolitan migration. ${ }^{32}$

32 It is also possible that the problem lies with the weaknesses pointed out in footnote 25 , namely the fact that censuses do not capture mobility and use official rather than indigenous divisions. 


\subsubsection{After controlling for exogenous factors (such as age and education), is there any change in the propensity of indigenous people to migrate at the levels of major and minor administrative divisions?}

The reasons why indigenous people are less likely to migrate are complex and cannot be fully elucidated using census data. Furthermore, as pointed out above, it may be inappropriate to refer to indigenous people in general, given the differences in mobility that ethnographic studies have identified among various peoples.

Nevertheless, census data do make it possible to quantify how much of this lower propensity to migrate is due to exogenous differences between indigenous and non-indigenous people. The aim is to identify whether the lower propensity is attributable to an underlying pattern of behaviour or simply a composition effect, i.e. a sociodemographic feature of indigenous people that makes for low rates of migration. Any attempt to answer that question must control for exogenous factors. There are several statistical procedures for doing this, and this document uses direct standardization with three main exogenous factors: sex, age and education. Direct standardization consists in applying a weighting based on the sex, age and education structure of non-indigenous people to the conditional probabilities (in terms of sex, age and education) of indigenous people's propensity to migrate. The sum of these probabilities gives a standardized probability, which corresponds to how likely indigenous people would be to migrate if they had the same sex, age and education structure as non-indigenous people. The results are shown in figure 1.

The main finding to have emerged from this exercise is that controlling for exogenous variables changes the previous table's results for minor administrative divisions: three countries show higher standarized probability of migration among indigenous people than among nonindigenous groups (Bolivia, Chile and Panama). This shows that there is a significant composition effect in some countries, although this is insufficient for debunking the prevailing hypothesis. Indeed, even after controlling for exogenous variables, there are still more cases where there is a higher probability of migration among non-indigenous people.

Figure 1

PROPORTION OF MIGRANTS (5 YEARS PRIOR TO CENSUS) BETWEEN MAJOR AND MINOR ADMINISTRATIVE DIVISIONS, BY INDIGENOUS, NON-INDIGENOUS AND INDIGENOUS TYPED BY AGE, GENDER AND EDUCATION OF NON INDIGENOUS PEOPLE

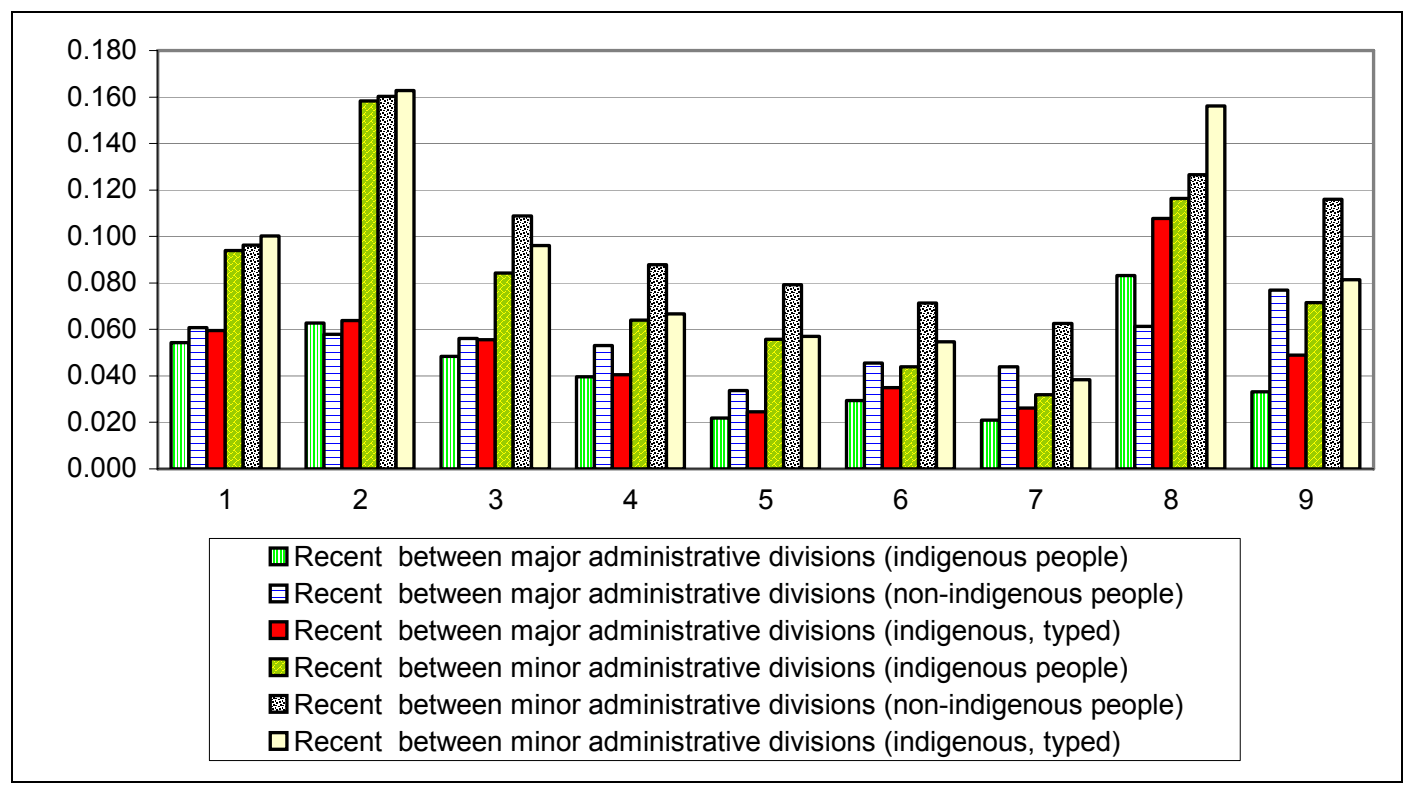

Source: Latin American and Caribbean Demographic Centre (CELADE) - Population Division of ECLAC, special processing of census microdatabases. 


\subsubsection{Where do indigenous people migrate to? Initial analysis at the level of major administrative divisions}

Special processing of census microdatabases makes it possible to construct migration matrices to identify flows between different subnational areas. For all censuses in the study, it is possible to produce migration matrices between major and minor administrative divisions, thereby identifying migratory flows, numbers of emigrants and immigrants and overall migratory balance for each major and minor administrative division. The same can be carried out for selected cities, and the matrix presented herein captures short- and long-distance movements. For a few countries, it is also possible to calculate urban-rural migration matrices. All the matrices can be used to obtain derived patterns and flow indicators, which enables a new and revealing set of calculations to be carried out (for more information, see Rodríguez 2004 and the database on internal migration in Latin America and the Caribbean (MIALC)). In addition, the availability of microdata means that differentiated analyses can be carried out for indigenous and non-indigenous people.

In terms of migration between political and administrative divisions, this document only examines migration flow between major administrative divisions. Although an analysis at the level of minor administrative divisions would be feasible, it is beyond the limits and aims of this study. Nevertheless, analyses of flows to and from selected cities are carried out using the groups of minor administrative divisions that make up cities. The first finding that emerges from these matrices is that, in most countries analysed (Bolivia, Brazil, Chile, Costa Rica, Ecuador, Guatemala, Honduras and Panama), the major administrative division of choice is the same for indigenous and non-indigenous migrants. ${ }^{33}$ In contrast, the second and third main administrative divisions showed greater disparities between indigenous and non-indigenous people, as the destinations of the former tended to be close to their historical population centres. One country with striking similarities between indigenous and non-indigenous people is Bolivia, as both populations gravitate to the same three major administrative divisions (Santa Cruz, Cochabamba and La Paz). In Mexico, on the other hand, Oaxaca is the major administrative division of destination for indigenous people, while the state of Mexico is the main attraction for non-indigenous people. In Paraguay, Canindeyu attracts the most indigenous people, while Central Department is the main pole of attraction for non-indigenous individuals.

Unlike the relative homogeneity in terms of major administrative divisions of destination, there is a much more marked disparity between indigenous and non-indigenous people in terms of divisions of origin. This is mainly due to the fact that indigenous populations are located in different areas from the non-indigenous population. Nevertheless, in three countries the top major administrative division of origin is the same for indigenous and non-indigenous people (São Paulo in Brazil, the Metropolitan Region in Chile and San José in Costa Rica), which is due to the fact that all three of those divisions are home to a significant proportion of the country's indigenous population and each had net out-migration rates. In other countries, such as Bolivia and Guatemala, the main major administrative divisions of origin (Potosí and Quiche, respectively) are also those with the highest proportion of indigenous people as they are home to indigenous settlements, as well as having net out-migration rates.

Panama is a special case because its indigenous population occupies clearly defined major administrative areas (indigenous territories, or comarcas). Table $2 \mathrm{a}$ shows that, in Panama, all major administrative divisions (indigenous comarcas and provinces) are losing population except Panama Province. Also, the highest rate of out-migration is for one of the comarcas (Kuna Yala, which is home to the Kuna people). In terms of lifetime migration, the figures suggest that indigenous major administrative divisions have net out-migration rates. Indeed, $40 \%$ of those born in the Kuna Yala comarca have left, and over $80 \%$ of those emigrants were living in Panama province in 2000. In the Ngobe Bugle comarca, about 15\% of those born there are lifetime emigrants,

33 The analysis is based on absolute figures, which means it may be affected by the population size of the major administrative divisions concerned. 
with most moving to Chiriquí and Veraguas (which forms a different migration pattern from the Kuna people). In any event, one distinctive characteristic of indigenous comarcas is that they have low numbers of immigrants, which may be due to objective conditions and the special status of those areas.

Table 2(a)

PANAMA 2000: MAJOR ADMINISTRATIVE DIVISIONS BY AMOUNT AND INTENSITY OF RECENT AND LIFETIME MIGRATION, TOTAL POPULATION

\begin{tabular}{l|r|r|r|r|r|r}
\hline \multirow{2}{*}{ Province } & \multicolumn{3}{|c|}{ Migration over past five years } & \multicolumn{2}{c}{ Lifetime migration } \\
\cline { 2 - 7 } & Immigrants & Emigrants & $\begin{array}{c}\text { Net } \\
\text { migration }\end{array}$ & $\begin{array}{c}\text { Rate of net } \\
\text { migration } \\
\mathbf{( \% )}\end{array}$ & Immigrants & Emigrants \\
\hline Bocas del Toro & 5,582 & 6,640 & $-1,058$ & -3.30 & 21,646 & 17,725 \\
Coclé & 7,178 & 18,535 & $-11,357$ & -14.84 & 24,511 & 75,629 \\
Colón & 9,103 & 9,511 & -408 & -0.55 & 34,529 & 32,488 \\
Chiriquí & 12,997 & 29,120 & $-16,123$ & -11.52 & 29,756 & 94,939 \\
Darién & 3,406 & 8,709 & $-5,303$ & -34.87 & 12,030 & 30,517 \\
Herrera & 4,488 & 10,700 & $-6,212$ & -15.37 & 13,002 & 44,071 \\
Los Santos & 4,115 & 9,758 & $-5,643$ & -17.01 & 9,559 & 56,862 \\
Panama & 99,283 & 20,507 & 78,776 & 16.08 & 384,979 & 49,558 \\
Veraguas & 5,784 & 26,466 & $-20,682$ & -24.81 & 17,150 & 110,316 \\
Kuna Yala comarca & $\mathbf{3 6 1}$ & $\mathbf{6 , 3 5 9}$ & $\mathbf{- 5 , 9 9 8}$ & $\mathbf{- 4 5 . 6 2}$ & $\mathbf{8 1 5}$ & $\mathbf{1 8 , 2 0 6}$ \\
Emberá comarca & $\mathbf{2 6 5}$ & $\mathbf{4 9 3}$ & $\mathbf{- 2 2 8}$ & $\mathbf{- 7 . 8 8}$ & $\mathbf{1 , 1 1 8}$ & $\mathbf{9 9 7}$ \\
Ngobe Bugle comarca & $\mathbf{1 , 0 9 6}$ & $\mathbf{6 , 8 6 0}$ & $\mathbf{- 5 , 7 6 4}$ & $\mathbf{- 1 4 . 3 7}$ & $\mathbf{3 , 1 9 4}$ & $\mathbf{2 0 , 9 8 1}$ \\
\hline
\end{tabular}

Source: database on internal migration in Latin America and the Caribbean (MIALC), www.eclac.cl/migracion/ migracion\%5Finterna

Table 2(b) includes the same calculations as in table 2(a) but only for the indigenous population. This pattern differs from the overall pattern mainly because, as shown in table 2(b), there are many more major administrative divisions displaying net in-migration. This is due to the fact that the indigenous exodus from comarcas has swelled the ranks of indigenous population in the rest of the country and not just in Panama province (which has the highest concentration of indigenous in-migration).

Table 2(b)

PANAMA 2000: MAJOR ADMINISTRATIVE DIVISIONS BY AMOUNT AND INTENSITY OF RECENT AND LIFETIME MIGRATION, INDIGENOUS POPULATION

\begin{tabular}{|c|c|c|c|c|c|c|}
\hline \multirow[b]{2}{*}{ Province } & \multicolumn{4}{|c|}{ Migration over past five years } & \multicolumn{2}{|c|}{ Lifetime migration } \\
\hline & Immigrants & Emigrants & $\begin{array}{c}\text { Net } \\
\text { migration }\end{array}$ & $\begin{array}{c}\text { Rate of net } \\
\text { migration (\%) }\end{array}$ & Immigrants & Emigrants \\
\hline Bocas del Toro & 2,595 & 1,378 & 1,217 & 6.2 & 10,972 & 3,202 \\
\hline Coclé & 148 & 126 & 22 & 8.7 & 317 & 389 \\
\hline Colón & 683 & 345 & 338 & 18.5 & 2,153 & 755 \\
\hline Chiriquí & 4,445 & 2,146 & 2,299 & 23.1 & 9,614 & 5,413 \\
\hline Darién & 348 & 2,188 & $-1,840$ & -37.0 & 832 & 6,119 \\
\hline Herrera & 120 & 55 & 65 & 50.3 & 233 & 150 \\
\hline Los Santos & 63 & 36 & 27 & 44.8 & 108 & 179 \\
\hline Panama & 8,832 & 621 & 8,211 & 57.7 & 23,203 & 1,338 \\
\hline Veraguas & 626 & 495 & 131 & 6.6 & 1,725 & 1,315 \\
\hline Kuna Yala comarca & 310 & 5,323 & $-5,013$ & -34.1 & 715 & 15,166 \\
\hline Emberá comarca & 219 & 425 & -206 & -6.6 & 941 & 842 \\
\hline Ngobe Bugle comarca & 908 & 6,159 & $-5,251$ & -11.6 & 2,642 & 18,587 \\
\hline
\end{tabular}

Source: database on internal migration in Latin America and the Caribbean (MIALC), www.eclac.cl/migracion/ migracion\%5Finterna/ 
Following this section, the next step is to go beyond these interesting but insufficient results. More full and detailed analysis is needed to capture the complexity of migration to and from indigenous areas. For instance, a sweeping overview of absolute figures may conceal flows that are numerically small but have a large impact in major administrative divisions with a mainly indigenous population, especially if people are migrating to work with existing natural resources in those areas. In summary, there are many analyses and calculations that still need to be carried out at the national level. In turn, these need to be supplemented with local and ethnographic studies to find out the impact of indigenous migration at the level of major administrative divisions.

\subsubsection{Where indigenous people migrate to: exchanges between urban and rural areas}

Only three censuses from the 2000 census round enable direct estimates to be made of rural to urban migration: Brazil, Panama and Nicaragua. This is because the censuses of these three countries contain questions (in different forms or based on proxy indicators) on whether people's current and previous places of residence were rural or urban. The replies make it possible to construct origin-destination matrices and/or establish typologies. This section is based on the latter, as they are more complete and interesting.

The choice of typology that can feasibly be constructed varies according to the country, as it depends on the questions in the migration section of the census. For Brazil, it is possible to produce a very detailed typology that identifies those who have never migrated, and among those who have migrated, then distinguishes those who have migrated between urban and rural areas in the five years prior to the census (1995-2000). The type of question used in this census makes it possible to identify the urban or rural area of origin down to the municipal level, thereby enabling the identification of intra-municipal migrants who move from urban-to-rural, rural-to-rural and urbanto-urban municipalities. Table 3 presents the relative figures for the typology ${ }^{34}$ cross-referenced with the question on ethnic group (basically concerning "colour or race") that was included in Brazil's 2000 census. The results confirm some well-known facts: the indigenous population in Brazil lives mainly in urban areas, although its level of urbanization is considerably lower than the national average. However, the results also reveal some new findings: (a) indigenous people have the highest level of "territorial stability", i.e. no change of residence in a lifetime $(61.5 \%$ for indigenous people, compared with $54.1 \%$ for "white" people and $59.3 \%$ for "black" people); (b) the proportion of indigenous people who migrate between urban and rural areas is very similar to that of the general population (around 11\%); (c) indigenous people have a higher proportion of rural-tourban migrants than the general population $(2.3 \%$ compared with $2.1 \%)$ and a lower than average proportion of urban-rural migrants $(1.3 \%$ compared with $1.4 \%)$-this shows that migration is promoting the urbanization of indigenous people; and (d) among indigenous people, the largest migratory flows $(5.9 \%)$ are between urban areas, although as expected from their below-average level of urbanization compared to national figures, indigenous populations have lower migration rates between cities and higher migration rates between rural areas.

34 The figure of 153 million is different from the almost 170 million counted in the 2000 census because the typology excludes children under five as it uses a question on residency five years earlier. There are two types of non-migrants: those who have never migrated from their municipality of birth, and those who have migrated but have not changed their place of residency in the last five years. 
Table 3

BRAZIL 2000: TYPOLOGY OF URBAN-RURAL MIGRATION, BY ETHNIC GROUP, RELATIVE FIGURES

\begin{tabular}{l|r|r|r|r|r|r}
\hline \multicolumn{1}{c|}{ Type of rural-urban migrant } & "White" & "Black" & "Asian" & "Mixed" & Indigenous & Total \\
\hline Urban never migrated & 44.1 & 44.9 & 35.8 & 41.8 & $\mathbf{2 3 . 1}$ & 43.1 \\
Rural never migrated & 10.0 & 14.4 & 5.1 & 16.3 & $\mathbf{3 8 . 4}$ & 12.8 \\
Urban non-migrant & 31.5 & 26.8 & 44.7 & 26.3 & $\mathbf{2 3 . 9}$ & 29.2 \\
Urban (rural migrant from same municipality) & 0.7 & 0.9 & 0.8 & 0.9 & $\mathbf{0 . 9}$ & 0.8 \\
Urban (urban migrant from other municipality) & 7.5 & 5.6 & 6.3 & 6.6 & $\mathbf{5 . 9}$ & 7.0 \\
Urban (rural migrant from other municipality) & 1.2 & 1.3 & 0.7 & 1.6 & $\mathbf{1 . 4}$ & 1.3 \\
Urban migrant from another country & 0.1 & 0.0 & 2.2 & 0.0 & $\mathbf{0 . 1}$ & 0.1 \\
Rural (urban migrant from same municipality) & 0.5 & 0.6 & 0.3 & 0.6 & $\mathbf{0 . 5}$ & 0.5 \\
Rural non-migrant & 3.1 & 3.8 & 3.1 & 4.0 & $\mathbf{3 . 7}$ & 3.5 \\
Rural (urban migrant from other municipality) & 0.8 & 0.9 & 0.5 & 1.0 & $\mathbf{0 . 8}$ & 0.9 \\
Rural (rural migrant from other municipality) & 0.6 & 0.8 & 0.3 & 0.9 & $\mathbf{1 . 2}$ & 0.8 \\
Rural migrant from another country & 0.0 & 0.0 & 0.2 & 0.0 & $\mathbf{0 . 1}$ & 0.0 \\
Total & 100.0 & 100.0 & 100.0 & 100.0 & $\mathbf{1 0 0 . 0}$ & 100.0 \\
Urban-rural migrants in last five years (all & $\mathbf{1 1 . 4}$ & $\mathbf{1 0 . 1}$ & $\mathbf{1 1 . 3}$ & $\mathbf{1 1 . 6}$ & $\mathbf{1 0 . 9}$ & $\mathbf{1 1 . 4}$ \\
categories) & $\mathbf{1 . 9}$ & $\mathbf{2 . 2}$ & $\mathbf{1 . 4}$ & $\mathbf{2 . 4}$ & $\mathbf{2 . 3}$ & $\mathbf{2 . 1}$ \\
Rural-urban migrants in last five years & $\mathbf{1 . 3}$ & $\mathbf{1 . 4}$ & $\mathbf{0 . 9}$ & $\mathbf{1 . 6}$ & $\mathbf{1 . 3}$ & $\mathbf{1 . 4}$ \\
Urban-rural migrants in last five years & & &
\end{tabular}

Source: Latin American and Caribbean Demographic Centre (CELADE) - Population Division of ECLAC, special processing of census microdatabases.

In Nicaragua (2005), census questions did not make it possible to identify those who "never migrated", but did reveal intra-municipal migration. Table 4 shows the relative figures for a feasible typology, (based on the question of residency five years earlier). Apart from confirming wellknown phenomena, such as the fact that indigenous people prefer to settle in rural areas, ${ }^{35}$ subsequent analyses enable the following conclusions to be drawn: (a) migration between urban and rural areas (in all directions) is slightly higher among indigenous people; (b) the main flow for indigenous and non-indigenous people is small-scale rural-to-urban migration; ${ }^{36}$ (c) migration between rural areas is more common among indigenous people; and (d) as a result of rural-to-urban migration, indigenous people should be becoming more urbanized in the wake of net out-migration from the countryside. ${ }^{37}$

35 This includes all those who described themselves as belonging to a specific indigenous people or ethnic group, and therefore includes Afro-descendents.

36 The indices were suspiciously high. A technical assessment of the census (unpublished and in the hands of the National Institute for Development Information (INIDE)) explains why the question used appears to over-estimate rural-to-urban migration (see http://www.inec.gob.ni/ ).

37 This does not necessarily mean that they are becoming urbanized, as there are several other sociodemographic processes that influence this trend. If they are becoming more urbanized, there is therefore no guarantee that the net transfer of indigenous people from the countryside to the city is the main cause. 
NICARAGUA 2005: TYPOLOGY OF URBAN-RURAL MIGRANTS (5 YEARS PRIOR TO THE CENSUS), BY INDIGENOUS OR NON-INDIGENOUS, RELATIVE FIGURES

\begin{tabular}{l|r|r|r}
\hline \multicolumn{1}{c|}{ Type of rural-urban migrant } & Indigenous & Non-indigenous & Total \\
\hline Intra-municipal urban non-migrant & 35.4 & 48.5 & 47.5 \\
Intra-municipal urban-rural migrant & 1.9 & 2.0 & 1.9 \\
Intra-municipal rural-urban migrant & 7.0 & 6.9 & 6.9 \\
Intra-municipal rural non-migrant & 50.8 & 38.3 & 39.3 \\
Inter-municipal urban-to-urban migrant & 1.5 & 1.5 & 1.5 \\
Inter-municipal urban-rural migrant & 0.7 & 0.7 & 0.7 \\
Inter-municipal rural-urban migrant & 0.7 & 0.7 & 0.7 \\
Inter-municipal rural-to-rural migrant & 2.1 & 1.4 & 1.4 \\
Total & 100.0 & 100.0 & 100.0 \\
\hline
\end{tabular}

Source: Latin American and Caribbean Demographic Centre (CELADE) - Population Division of ECLAC special processing of census microdatabases.

For Panama, the census questions make for a less-detailed typology than in the case of Brazil. Indeed, it is only possible to identify flows between urban and rural areas of different districts, and thus information on flows within those districts is lost (see table 5). On the other hand, the information for Panama does make it possible to observe the heterogeneity within indigenous groups, especially in terms of migration patterns at the level of major administrative divisions as pointed out earlier. Table 5 shows that, among indigenous people: (a) the high rural percentages show that the main form of migration involves rural origins and destinations $(4.8 \%)$, followed by rural-to-urban migration (4.3\%), and in third place urban-to-urban migration (which is the main form of migration among non-indigenous people); (b) there is a large difference between urban-tourban migration and urban-to-rural migration $(0.9 \%)$, which means that internal migration is also promoting the urbanization of indigenous people in Panama; (c) there is little urban-to-rural migration (possibly return migration), with little variation among indigenous peoples; (d) there is considerable heterogeneity among indigenous peoples, some of which are surprisingly mobile (like the rural-rural flows of the Bugle people and the rural-to-urban flows of the Kuna and the Embera).

Table 5

PANAMA 2000: TYPOLOGY OF URBAN-RURAL MIGRANTS, BY INDIGENOUS GROUP

\begin{tabular}{l|r|r|r|r|r|r|r}
\hline \multicolumn{1}{c|}{ People } & $\begin{array}{c}\text { Urban non- } \\
\text { migrant }\end{array}$ & $\begin{array}{c}\text { Rural non- } \\
\text { migrant }\end{array}$ & $\begin{array}{c}\text { Urban-to-urban } \\
\text { migrant }\end{array}$ & $\begin{array}{c}\text { Rural-to- } \\
\text { rural migrant }\end{array}$ & $\begin{array}{c}\text { Rural-to-urban } \\
\text { migrant }\end{array}$ & $\begin{array}{c}\text { Urban-to-rural } \\
\text { migrant }\end{array}$ & Total \\
\hline Kuna & 24.1 & 60.0 & 3.9 & 1.4 & 9.4 & 1.3 & 100.0 \\
Ngobe & 7.0 & 85.2 & 0.3 & 5.2 & 1.7 & 0.7 & 100.0 \\
Bugle & 13.2 & 66.6 & 1.0 & 12.7 & 5.3 & 1.1 & 100.0 \\
Teribe & 15.2 & 75.2 & 2.4 & 3.4 & 2.7 & 1.0 & 100.0 \\
Bokota & 16.6 & 65.3 & 1.2 & 10.2 & 5.5 & 1.1 & 100.0 \\
Embera & 17.1 & 65.9 & 3.4 & 4.7 & 7.8 & 1.1 & 100.0 \\
Wounaan & 17.9 & 67.7 & 1.7 & 6.0 & 5.4 & 1.3 & 100.0 \\
Bri bri & 54.0 & 26.9 & 12.4 & 2.7 & 3.0 & 1.0 & 100.0 \\
Indigenous total & $\mathbf{1 2 . 9}$ & $\mathbf{7 5 . 6}$ & $\mathbf{1 . 6}$ & $\mathbf{4 . 8}$ & $\mathbf{4 . 3}$ & $\mathbf{0 . 9}$ & $\mathbf{1 0 0 . 0}$ \\
None & $\mathbf{5 7 . 7}$ & $\mathbf{3 0 . 0}$ & $\mathbf{6 . 8}$ & $\mathbf{1 . 4}$ & $\mathbf{3 . 0}$ & $\mathbf{1 . 3}$ & $\mathbf{1 0 0 . 0}$ \\
Undeclared & 62.7 & 26.9 & 5.3 & 2.0 & 2.5 & 0.6 & 100.0 \\
Total & $\mathbf{5 3 . 5}$ & $\mathbf{3 4 . 3}$ & $\mathbf{6 . 3}$ & $\mathbf{1 . 7}$ & $\mathbf{3 . 1}$ & $\mathbf{1 . 2}$ & $\mathbf{1 0 0 . 0}$ \\
\hline
\end{tabular}

Source: Latin American and Caribbean Demographic Centre (CELADE) - Population Division of ECLAC, special processing of census microdatabases. 
The main conclusion to be drawn from the foregoing results is that the internal migration of indigenous people promotes their urbanization, even when the latter also has other determining factors. As shown below, although the magnitudes involved do not warrant reference to an exodus or total abandonment of ancestral lands (mainly located in rural areas), the disparities between historically indigenous locations and cities certainly generate incentives for migration, especially among young people.

\subsubsection{What are the characteristics of indigenous migrants?}

Selectivity is one of the most documented features of all forms of migration (Villa, 1991; Welti, 1997). This refers to the way in which the propensity to migrate varies according to people's characteristics, which means that migrants are not a representative sample of the population. It is well known, for instance, that the likelihood of migrating varies along the life cycle. The probability of migrating is significantly higher among young people (aged 15 to 29), which is why that age group tends to be over-represented among migrants There is also a well-documented gender bias in migration, although this really depends on regional and cultural characteristics, as men are more likely to migrate in some contexts while women are more likely to do so in other areas (with the latter prevailing in Latin America and the Caribbean, according to previous research such as Rodríguez, 2004). In any event, this selectivity is a key factor of the impact of migration on areas of origin and destination, in terms of its direct effect on population growth, as well as its influence on population composition at origin and destination.

Although significant progress has been made in estimating selectivity and its effect on the population as a whole (Rodríguez, 2004), there have been fewer advances in terms of the indigenous population in particular, which is also affected by selectivity (as shown in table 6). Table 6 shows three forms of migration bias among major administrative divisions and among minor administrative divisions: gender (reflected in the proportion of males); education (proportion with and without university education); and age (percentage of young people). The figures from table 6 will be analysed in the light of differences between the two types of migration, with a main focus on migration selectivity among indigenous people and a secondary focus on selectivity among non-indigenous people.

There is no set pattern in terms of the sex ratio, as four of the ten countries (Brazil, Guatemala, Mexico and Honduras) have lower sex ratios among migrants between major administrative divisions, while the remaining six have lower indices among non-migrants at the level of major administrative divisions. A similar phenomenon is observed for migrants between minor administrative divisions. In the case of indigenous people, there appears to be no female majority among migrants — which has often been highlighted as a specificity of Latin America, since the earliest research carried out into this issue (Cardona and Simmons, 1975; Chant, 1999). ${ }^{38}$ However, in keeping with the findings of Rodríguez (2004), female domination of internal migration has been losing ground. This certainly applies to non-indigenous people, as it is only in the case of migrants at the level of minor administrative divisions that more countries have female selectivity (five countries, compared with four with masculine selectivity - Brazil was excluded). Female selectivity, which is increasingly losing significance globally, appears to be more the exception than the rule among indigenous people. Panama provides a striking example, as genderbased selectivity for migration is clearly masculine among indigenous people and female among non-indigenous people. These results should be considered as a preliminary analysis, as they could be attributable to combinations of various migratory flows, each with its own gender selectivity (as

38 Up until the early 1980s, this peculiarity was attributed to the high proportion of rural-to-urban migration, while migration towards agricultural borders was male dominated (Cardona and Simmons 1975). However, the analysis of census microdatabases from the 1980, 1990 and 2000 rounds carried out by Rodríguez (2004) concludes that women have traditionally formed the majority in migration flows among major administrative divisions and among minor administrative divisions, although census results from the 2000 round concerning recent migration suggest that this may now be changing. 
shown by the counterpoint between rural-to-urban flows and flows to border areas highlighted in early research (Cardona and Simmons, 1975)). Any migratory movement may also be a combination of the migration flows of different indigenous groups, which may each have their own specific gender selectivity.

As far as education is concerned, the pattern does fit in with hegemonic theories and previous research: selectivity is incrementally associated with education (Delaunay, 2003; Rodríguez, 2004). In all countries analysed, indigenous migrants include a higher proportion of well-educated people (university level) and a smaller proportion of uneducated people. These differences are striking in some countries. In Brazil, for instance, the proportion of uneducated people is $13.6 \%$ among indigenous people migrating between major administrative divisions, compared with $30.9 \%$ for non-migrant indigenous people. This pattern is also systematically observable (apart from a couple of exceptions) among non-indigenous people, which suggests that educational selectivity is not affected by ethnic group. In areas of indigenous settlement, which tend to be more rural and characterized by net out-migration, this pattern implies a potential loss of human resources, as those who out-migrate tend to be more educated than those who remain (or in-migrate). ${ }^{39}$

As far as age is concerned, indigenous people are also shown to be influenced by the strong link between life cycle and migration. At the level of major administrative divisions, the proportion of young people $\mathrm{e}^{40}$ among indigenous migrants is systematically above $40 \%$ and sometimes reaches $50 \%$. Among non-migrant indigenous people, the proportion of young people is $35 \%$ and sometimes almost as low as $25 \%$. This pattern does not apply exclusively to indigenous people, as non-indigenous migrants also have a higher proportion of young people than non-migrant nonindigenous groups. Differences in the proportion of young people in migrant and non-migrant groups are more apparent among indigenous people, which implies that age selectivity is more significant in indigenous populations.

Table 6

MIGRANTS BETWEEN MAJOR ADMINISTRATIVE DIVISIONS AND BETWEEN MINOR ADMINISTRATIVE DIVISIONS, SELECTED CHARACTERISTICS BASED ON INDIGENOUS OR NON-INDIGENOUS PEOPLE

\begin{tabular}{|c|c|c|c|c|c|c|c|c|c|}
\hline & \multirow[b]{2}{*}{$\begin{array}{c}\text { Country and } \\
\text { year }\end{array}$} & \multicolumn{4}{|c|}{$\begin{array}{c}\text { Recent migration between major administrative } \\
\text { divisions }\end{array}$} & \multicolumn{4}{|c|}{$\begin{array}{l}\text { Recent migration between minor administrative } \\
\text { divisions }\end{array}$} \\
\hline & & $\begin{array}{l}\text { Indigenous } \\
\text { migrant }\end{array}$ & $\begin{array}{c}\text { Non- } \\
\text { indigenous } \\
\text { migrant }\end{array}$ & $\begin{array}{c}\text { Indigenous } \\
\text { non- } \\
\text { migrant }\end{array}$ & \begin{tabular}{|c|} 
Non- \\
indigenous \\
non-migrant
\end{tabular} & $\begin{array}{c}\text { Indigenous } \\
\text { migrant }\end{array}$ & $\begin{array}{c}\text { Non- } \\
\text { indigenous } \\
\text { migrant }\end{array}$ & $\begin{array}{c}\text { Indigenous } \\
\text { non- } \\
\text { migrant }\end{array}$ & $\begin{array}{c}\text { Non- } \\
\text { indigenous } \\
\text { non-migrant }\end{array}$ \\
\hline \multirow{10}{*}{ 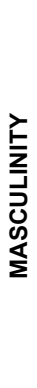 } & Bolivia 2001 & 94.8 & 97.3 & 94.0 & 95.7 & 96.0 & 98.1 & 93.9 & 95.6 \\
\hline & Brazil 2000 & 92.0 & 97.4 & 98.6 & 95.9 & \multicolumn{4}{|c|}{ Unavailable } \\
\hline & Chile 2002 & 105.4 & 109.0 & 100.9 & 94.4 & 98.6 & 101.4 & 101.7 & 94.1 \\
\hline & Costa Rica 2000 & 112.9 & 104.8 & 106.7 & 98.9 & 111.1 & 102.1 & 106.7 & 98.9 \\
\hline & Ecuador 2001 & 108.8 & 105.4 & 91.9 & 96.7 & 101.9 & 100.6 & 91.9 & 96.8 \\
\hline & Guatemala 2002 & 107.6 & 90.8 & 94.9 & 93.7 & 100.5 & 91.7 & 94.9 & 93.7 \\
\hline & Mexico 2000 & 97.2 & 94.5 & 99.3 & 93.9 & 97.6 & 91.9 & 99.3 & 94.0 \\
\hline & Honduras 2001 & 85.4 & 88.6 & 99.2 & 97.4 & 83.1 & 89.1 & 99.5 & 97.6 \\
\hline & Panama 2000 & 124.8 & 97.0 & 103.2 & 101.5 & 124.2 & 95.5 & 102.5 & 102.0 \\
\hline & Paraguay 2002 & 115.9 & 95.2 & 106.8 & 101.6 & 116.4 & 96.6 & 106.3 & 101.7 \\
\hline
\end{tabular}

(Continued)

39 This conclusion may be influenced by an issue of endogeneity, as migration could be a necessary stepping stone to higher levels of schooling. This problem is mainly contained by the fact that the migration in question is recent, and the above-mentioned effect cannot relate to more than four additional years of schooling. Given that this is nonetheless high, tests were carried out on population aged over 30 , as such people were taken to have already finished their education when they migrated at some point during the five years prior to the census. The results confirm educational selectivity among migrants.

40 Measured as the percentage of people aged 15 to 29 within the total population of those aged five and over (by definition, children aged 0 to 4 are excluded from the analysis of recent migration). 
Table 6 (Concluded)

\begin{tabular}{|c|c|c|c|c|c|c|c|c|c|}
\hline & \multirow{2}{*}{$\begin{array}{c}\text { Country and } \\
\text { year }\end{array}$} & \multicolumn{4}{|c|}{$\begin{array}{c}\text { Recent migration between major administrative } \\
\text { divisions }\end{array}$} & \multicolumn{4}{|c|}{$\begin{array}{c}\text { Recent migration between minor administrative } \\
\text { divisions }\end{array}$} \\
\hline & & $\begin{array}{l}\text { Indigenous } \\
\text { migrant }\end{array}$ & $\begin{array}{c}\text { Non- } \\
\text { indigenous } \\
\text { migrant }\end{array}$ & \begin{tabular}{|c|}
$\begin{array}{c}\text { Indigenous } \\
\text { non- } \\
\text { migrant }\end{array}$ \\
\end{tabular} & \begin{tabular}{|c|} 
Non- \\
indigenous \\
non-migrant
\end{tabular} & $\begin{array}{c}\text { Indigeno } \\
\text { us } \\
\text { migrant }\end{array}$ & $\begin{array}{c}\text { Non- } \\
\text { indigenous } \\
\text { migrant }\end{array}$ & $\begin{array}{c}\text { Indigenous } \\
\text { non- } \\
\text { migrant }\end{array}$ & $\begin{array}{c}\text { Non- } \\
\text { indigenous } \\
\text { non-migrant }\end{array}$ \\
\hline \multirow{10}{*}{ 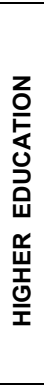 } & Bolivia 2001 & 16.4 & 13.2 & 12.0 & 8.4 & 13.7 & 11.3 & 12.1 & 8.4 \\
\hline & Brazil 2000 & 3.7 & 6.7 & 1.8 & 5.5 & \multicolumn{4}{|c|}{ Unavailable } \\
\hline & Chile 2002 & 14.6 & 29.2 & 8.8 & 17.7 & 14.2 & 28.1 & 8.2 & 16.5 \\
\hline & Costa Rica 2000 & 5.3 & 12.3 & 2.6 & 10.1 & 4.9 & 13.1 & 2.5 & 9.9 \\
\hline & Ecuador 2001 & 3.0 & 11.4 & 1.6 & 11.4 & 3.4 & 11.6 & 1.6 & 11.4 \\
\hline & Guatemala 2002 & 1.6 & 6.3 & 0.7 & 5.6 & 1.2 & 9.0 & 0.7 & 5.4 \\
\hline & Mexico 2000 & 4.2 & 13.4 & 2.2 & 8.8 & 5.9 & 14.5 & 2.1 & 8.6 \\
\hline & Honduras 2001 & 4.6 & 4.9 & 1.1 & 3.9 & 3.6 & 4.5 & 1.0 & 3.9 \\
\hline & Panama 2000 & 2.3 & 15.7 & 1.3 & 12.9 & 2.8 & 17.0 & 1.2 & 12.5 \\
\hline & Paraguay 2002 & 0.7 & 9.3 & 0.1 & 6.9 & 0.4 & 8.3 & 0.1 & 6.9 \\
\hline \multirow{10}{*}{ 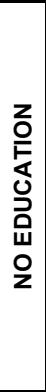 } & Bolivia 2001 & 7.5 & 9.1 & 10.9 & 15.3 & 8.1 & 9.7 & 11.0 & 15.5 \\
\hline & Brazil 2000 & 13.6 & 12.6 & 30.9 & 15.1 & \multicolumn{4}{|c|}{ Unavailable } \\
\hline & Chile 2002 & 6.6 & 5.1 & 10.5 & 6.7 & 6.7 & 5.4 & 10.9 & 6.8 \\
\hline & Costa Rica 2000 & 17.3 & 10.5 & 28.4 & 9.9 & 17.7 & 10.2 & 28.8 & 9.9 \\
\hline & Ecuador 2001 & 17.2 & 9.9 & 29.8 & 12.2 & 17.8 & 10.1 & 30.1 & 12.3 \\
\hline & Guatemala 2002 & 36.3 & 17.0 & 43.4 & 20.2 & 43.2 & 15.6 & 43.2 & 20.5 \\
\hline & Mexico 2000 & 19.1 & 9.4 & 26.3 & 11.9 & 19.2 & 9.4 & 26.4 & 12.0 \\
\hline & Honduras 2001 & 20.1 & 20.1 & 33.5 & 25.4 & 22.7 & 21.3 & 33.6 & 25.5 \\
\hline & Panama 2000 & 25.7 & 6.2 & 36.7 & 8.4 & 24.8 & 6.1 & 37.2 & 8.5 \\
\hline & Paraguay 2002 & 38.5 & 10.0 & 45.6 & 12.7 & 42.3 & 10.9 & 45.6 & 12.7 \\
\hline \multirow{10}{*}{$\begin{array}{l}\text { I } \\
\text { 온 }\end{array}$} & Bolivia 2001 & 46.6 & 46.3 & 33.9 & 30.2 & 46.0 & 45.2 & 33.4 & 29.6 \\
\hline & Brazil 2000 & 45.5 & 42.9 & 25.3 & 31.5 & \multicolumn{4}{|c|}{ Unavailable } \\
\hline & Chile 2002 & 45.1 & 38.9 & 26.4 & 25.4 & 40.0 & 34.2 & 25.3 & 24.6 \\
\hline & Costa Rica 2000 & 41.5 & 37.2 & 30.8 & 29.0 & 39.8 & 36.0 & 30.5 & 28.7 \\
\hline & Ecuador 2001 & 54.1 & 45.7 & 27.6 & 29.3 & 49.6 & 42.5 & 27.2 & 28.9 \\
\hline & Guatemala 2002 & 47.4 & 44.8 & 33.5 & 33.2 & 40.7 & 39.7 & 33.4 & 33.1 \\
\hline & Mexico 2000 & 51.0 & 43.3 & 30.8 & 32.1 & 47.5 & 41.7 & 30.5 & 31.8 \\
\hline & Honduras 2001 & 47.9 & 49.0 & 31.3 & 32.6 & 46.9 & 46.8 & 31.1 & 32.3 \\
\hline & Panama 2000 & 48.5 & 43.8 & 31.3 & 29.1 & 48.4 & 40.3 & 30.6 & 28.5 \\
\hline & Paraguay 2002 & 37.8 & 44.7 & 30.9 & 29.7 & 36.3 & 43.0 & 30.7 & 29.2 \\
\hline
\end{tabular}

Source: Latin American and Caribbean Demographic Centre (CELADE) - Population Division of ECLAC, special processing of census microdatabases.

An examination of rural-to-urban migration reveals diverse selectivity on the basis of gender and regular selectivity patterns for age and education among indigenous people (see tables 7 and 8). While Brazil confirms the historical hypotheses on the prevalence of women in rural-to-urban migratory flows (among indigenous groups and "white" people), Panama's rural-to-urban migration displays male selectivity among indigenous people and female selectivity among non-indigenous groups. In both countries, migration between urban areas shows male selectivity among indigenous and non-indigenous people alike. In addition, indigenous people who move from the countryside to the city have much higher levels of schooling than those who remain in rural areas, although these levels are lower than those of urban indigenous people, who are in turn educationally outdone by indigenous urban-to-urban migrants. Generally speaking, indigenous people who do not leave the countryside have very low levels of education, which is attributable to extrinsic factors (population dominated by children and older people) as well as the lack of educational opportunities in rural areas. Lastly, the flow of indigenous people from the countryside to the city includes a strikingly high proportion of young people. In summary, then, indigenous rural-to-urban out-migration clearly involves a human resources drain on the historical habitats of these peoples, as their young and most educated people leave. This appears to be due to a combination of factors: some "push" 
factors (people go to the city to seek opportunities not offered in the territory of origin), certain community practices (promoting out-migration among young people) and other strategic factors (encouraging youth migration to maximize the benefits of remittances and avoid the negative impacts of family break-up).

Table 7

BRAZIL 2000: MIGRANTS BETWEEN URBAN AND RURAL AREAS, SELECTED CHARACTERISTICS BASED ON INDIGENOUS OR NON-INDIGENOUS POPULATION

\begin{tabular}{|c|c|c|c|c|c|c|c|c|}
\hline \multirow{2}{*}{$\begin{array}{c}\text { Type of rural-urban } \\
\text { migrant }\end{array}$} & \multicolumn{2}{|c|}{ Sex ratio } & \multicolumn{2}{|c|}{ University } & \multicolumn{2}{|c|}{ No education } & \multicolumn{2}{|c|}{$\begin{array}{l}\text { Percentage of } \\
\text { young people }\end{array}$} \\
\hline & White & Indigenous & White & Indigenous & White & Indigenous & White & Indigenous \\
\hline Urban never migrated & 93 & 101 & 25 & 12 & 13 & 18 & 35 & 36 \\
\hline Rural never migrated & 107 & 109 & 5 & 1 & 24 & 53 & 31 & 32 \\
\hline Urban non-migrant & 84 & 81 & 28 & 16 & 9 & 15 & 22 & 21 \\
\hline $\begin{array}{l}\text { Urban (rural migrant } \\
\text { from same } \\
\text { municipality) }\end{array}$ & 98 & 96 & 10 & 5 & 19 & 32 & 26 & 27 \\
\hline $\begin{array}{l}\text { Urban (urban migrant } \\
\text { from other municipality) }\end{array}$ & 89 & 88 & 30 & 17 & 10 & 12 & 38 & 41 \\
\hline $\begin{array}{l}\text { Urban (rural migrant } \\
\text { from other municipality) }\end{array}$ & 93 & 89 & 10 & 5 & 17 & 22 & 44 & 44 \\
\hline $\begin{array}{l}\text { Urban migrant from } \\
\text { another country }\end{array}$ & 112 & 101 & 54 & 44 & 10 & 8 & 29 & 48 \\
\hline $\begin{array}{l}\text { Rural (urban migrant } \\
\text { from same } \\
\text { municipality) }\end{array}$ & 96 & 91 & 13 & 9 & 13 & 24 & 28 & 24 \\
\hline Rural non-migrant & 101 & 115 & 6 & 3 & 20 & 39 & 22 & 24 \\
\hline $\begin{array}{l}\text { Rural (urban migrant } \\
\text { from other municipality) }\end{array}$ & 104 & 103 & 13 & 7 & 16 & 26 & 35 & 39 \\
\hline $\begin{array}{l}\text { Rural (rural migrant } \\
\text { from other municipality }\end{array}$ & 107 & 121 & 3 & 2 & 22 & 43 & 36 & 36 \\
\hline $\begin{array}{l}\text { Rural migrant from } \\
\text { another country }\end{array}$ & 123 & 176 & 13 & 3 & 21 & 34 & 31 & 60 \\
\hline Total & 91 & 99 & 23 & 8 & 13 & 32 & 30 & 31 \\
\hline
\end{tabular}

Source: Latin American and Caribbean Demographic Centre (CELADE) - Population Division of ECLAC, special processing of census microdatabases.

Table 8

PANAMA 2000: MIGRANTS BETWEEN URBAN AND RURAL AREAS, SELECTED CHARACTERISTICS BASED ON INDIGENOUS OR NON-INDIGENOUS POPULATION

\begin{tabular}{l|l|r|r|r|r|r|r|r}
\hline \multicolumn{1}{c|}{ Indicator } & $\begin{array}{c}\text { Indigenous } \\
\text { identity }\end{array}$ & $\begin{array}{c}\text { Urban } \\
\text { non- } \\
\text { migrant }\end{array}$ & $\begin{array}{c}\text { Rural } \\
\text { non- } \\
\text { migrant }\end{array}$ & $\begin{array}{c}\text { Urban- } \\
\text { urban } \\
\text { migrant }\end{array}$ & $\begin{array}{c}\text { Rural- } \\
\text { rural } \\
\text { migrant }\end{array}$ & $\begin{array}{c}\text { Rural-to- } \\
\text { urban } \\
\text { migrant }\end{array}$ & $\begin{array}{c}\text { Urban- } \\
\text { to-rural } \\
\text { migrant }\end{array}$ & Total \\
\hline Sex ratio & Indigenous & 113 & 100 & 116 & 136 & 113 & 121 & 104 \\
& Non-indigenous & 95 & 116 & 94 & 110 & 88 & 105 & 101 \\
\hline Proportion with university & Indigenous & 5 & 0 & 7 & 1 & 3 & 3 & 1 \\
education & Non-indigenous & 16 & 3 & 22 & 3 & 10 & 10 & 12 \\
\hline Proportion with no education & Indigenous & 17 & 40 & 10 & 36 & 17 & 25 & 36 \\
& Non-indigenous & 5 & 13 & 4 & 13 & 5 & 9 & 8 \\
\hline Proportion of young people & Indigenous & 34.7 & 29.6 & 46.4 & 47.8 & 50.8 & 41.5 & 32.4 \\
& Non-indigenous & 29.2 & 26.6 & 39.0 & 38.5 & 45.7 & 35.5 & 29.2 \\
\hline
\end{tabular}

Source: Latin American and Caribbean Demographic Centre (CELADE) - Population Division of ECLAC, special processing of census microdatabases. 


\subsubsection{How do indigenous people move around in relation to selected cities?}

Rural-urban flows are aggregated and do not reveal the migration dynamics of cities. Table 9 gives results that offer a completely new way of approaching those dynamics. For each country, the most highly populated urban centres were selected ${ }^{41}$ and ad hoc migration matrices were constructed to identify exchanges between the city and both its surrounding area (other minor administrative divisions of the major one in which the metropolitan area is located) and further afield (minor divisions of other major administrative divisions). The example in table 9 is from La Paz, Bolivia, where the segmentation of the area into two parts (La Paz and El Alto) makes it more complex and therefore more illustrative than consolidated urban centres. The matrix also includes immigrants from abroad by nationality (so that returning migrants can be distinguished from nonnative migrants). However, that piece of data - which is available for all matrices - will not be used here as the remit of this study is internal rather than international migration.

Table 9 demonstrates that the urban agglomeration of La Paz (encompassing the cities of La Paz and El Alto) recorded positive net migration of around 5,000 people between 1996 and 2001, although this was mainly due to dynamics associated with El Alto and to the exchange of indigenous people. In actual fact, the city of $\mathrm{La} \mathrm{Paz} \mathrm{lost} \mathrm{40,000} \mathrm{people} \mathrm{to} \mathrm{migration} \mathrm{during} \mathrm{that} \mathrm{period.} \mathrm{Of} \mathrm{that} \mathrm{loss,} 30 \%$ is due to exchanges with El Alto, and $70 \%$ is due to exchanges with the rest of the country. The city of El Alto, on the other hand, gained around 45,000 people, mainly thanks to exchanges with the rest of La Paz province and then to exchanges with the city of La Paz. Perhaps the most important point to be gleaned from these data is that the metropolitan centre La Paz only remains a pole of attraction for indigenous people, as it has become a place of net out-migration for non-indigenous people.

Table 9

AD HOC RECENT MIGRATION MATRIX (1996-2002) FOR LA PAZ, BY INDIGENOUS OR NON INDIGENOUS POPULATION

\begin{tabular}{l|l|r|r|r|r|r}
\hline \multirow{2}{*}{$\begin{array}{l}\text { Usual place of } \\
\text { residence }\end{array}$} & \multirow{2}{*}{$\begin{array}{c}\text { Indigenous } \\
\text { identity }\end{array}$} & \multicolumn{4}{|c|}{ Residence 5 years earlier } & \multirow{2}{*}{ Total } \\
\cline { 3 - 6 } & La Paz & El Alto City & Rest of province & Rest of country & \\
\hline La Paz & Indigenous & 391,967 & 3,851 & 13,909 & 11,622 & 421,349 \\
& Non-indigenous & 245,480 & 1,553 & 3,091 & 10,103 & 260,227 \\
& Total & 637,447 & 5,404 & 17,000 & 21,725 & 681,576 \\
\hline El Alto City & Indigenous & 13,593 & 382,526 & 28,948 & 7,824 & 432,891 \\
& Non-indigenous & 3,616 & 89,805 & 3,552 & 2,266 & 99,239 \\
& Total & 17,209 & 472,331 & 32,500 & 10,090 & 532,130 \\
\hline Rest of & Indigenous & 14,940 & 3,956 & 671,450 & 5,874 & 696,220 \\
province & Non-indigenous & 3,025 & 478 & 63,694 & 2,047 & 69,244 \\
& Total & 17,965 & 4,434 & 735,144 & 7,921 & 765,464 \\
\hline Rest of country & Indigenous & 28,283 & 2,912 & 8,754 & $2,638,474$ & $2,678,423$ \\
& Non-indigenous & 21,474 & 1,013 & 3,298 & $2,102,922$ & $2,128,707$ \\
& Total & 49,757 & 3,925 & 12,052 & $4,741,396$ & $4,807,130$ \\
\hline Total & Indigenous & 448,783 & 393,245 & 723,061 & $2,663,794$ & $4,228,883$ \\
& Non-indigenous & 273,595 & 92,849 & 73,635 & $2,117,338$ & $2,557,417$ \\
& Total & 722,378 & 486,094 & 796,696 & $4,781,132$ & $6,786,300$ \\
\hline
\end{tabular}

Source: Latin American and Caribbean Demographic Centre (CELADE) - Population Division of ECLAC, special processing of census microdatabases.

41 Geographical selection from the System for the Retrieval of Census Data for Small Areas by Microcomputer (Redatam), which captures and groups the minor administrative divisions (municipalities, communes and districts) of each built-up area in accordance with the definition given in the database of the CELADE project on Spatial distribution and urbanization in Latin America and the Caribbean (DEPUALC) (www.eclac.cl/celade/depualc/). The results would naturally be different if, for each country, the three cities with the largest indigenous populations had been chosen rather than the three most highly populated in general. 
According to table 10, main cities remain attractive for indigenous people as they are mainly places of net in-migration. This is mainly due to the power of attraction these cities hold over indigenous people living relatively far away, as the exchange of indigenous people between these cities and their immediate surroundings is one of net out-migration. This may be attributable to the fact that urban indigenous people also participate in the processes of under-urbanization and "concentrated deconcentration" described in the literature (Rodríguez, 2004).

Although net in-migration or out-migration to/from cities is usually of the same sign (positive or negative) for indigenous and non-indigenous groups, it is not uncommon for there to be differences. In addition to the above-mentioned case of $\mathrm{La} \mathrm{Paz}$, this situation also applies to Cochabamba, Rio de Janeiro, Tegucigalpa, Mexico City, Guadalajara, Asunción, Ciudad del Este and Encarnación. This is significant as it suggests different push and pull factors for indigenous and non-indigenous people, which is a matter that should be examined in more detail in future research.

Table 10 INDICATORS OF INDIGENOUS AND NON-INDIGENOUS INTERNAL MIGRATION FOR THE THREE MOST HIGHLY POPULATED CITIES OF 10 LATIN AMERICAN COUNTRIES

\begin{tabular}{|c|c|c|c|c|c|c|c|c|c|}
\hline \multirow[b]{2}{*}{$\begin{array}{l}\text { Country } \\
\text { and year }\end{array}$} & \multirow[b]{2}{*}{ City } & \multicolumn{4}{|c|}{ Indigenous } & \multicolumn{4}{|c|}{ Non-indigenous } \\
\hline & & $\begin{array}{c}\text { Net } \\
\text { migration }\end{array}$ & $\begin{array}{c}\text { Rate } \\
\text { (per } \\
1000)\end{array}$ & \begin{tabular}{|c} 
Net migration \\
surrounding \\
areas
\end{tabular} & \begin{tabular}{|c|} 
Net \\
migration \\
remote areas
\end{tabular} & $\begin{array}{c}\text { Net } \\
\text { migration }\end{array}$ & $\begin{array}{c}\begin{array}{l}\text { Rate } \\
\text { (per } \\
1000)\end{array} \\
\end{array}$ & $\begin{array}{c}\text { Net migration } \\
\text { surrounding } \\
\text { areas }\end{array}$ & \begin{tabular}{|c|} 
Net \\
migration \\
remote areas
\end{tabular} \\
\hline \multirow[t]{3}{*}{ Bolivia, 2001} & La Paz & \multicolumn{4}{|c|}{ See table 9} & \multicolumn{4}{|c|}{ See table 9} \\
\hline & Santa Cruz & 24,279 & 17.9 & -338 & 24,617 & 21,532 & 7.0 & 2,110 & 19,422 \\
\hline & Cochabamba & 752 & 0.6 & $-1,159$ & 1,911 & $-2,528$ & -3.0 & $-1,242$ & $-1,286$ \\
\hline \multirow[t]{3}{*}{ Brazil, 2000} & São Paulo & -164 & -1.1 & -747 & 583 & $-231,657$ & -2.9 & $-339,707$ & 108,050 \\
\hline & Rio de Janeiro & 435 & 3.1 & -175 & 610 & $-29,854$ & -0.6 & $-49,505$ & 19,651 \\
\hline & Belo Horizonte & 311 & 4.3 & 89 & 222 & 61,886 & 3.4 & 42,691 & 19,195 \\
\hline \multirow[t]{3}{*}{ Chile, 2002} & Santiago & -411 & -0.5 & -947 & 536 & $-49,306$ & -2.1 & $-30,945$ & $-18,361$ \\
\hline & Valparaiso & 231 & 5.4 & 24 & 207 & 8,927 & 2.5 & 1,361 & 7,566 \\
\hline & Concepción & -387 & -5.5 & -46 & -341 & $-7,438$ & -2.5 & 711 & $-8,149$ \\
\hline \multirow{3}{*}{$\begin{array}{l}\text { Costa Rica, } \\
2000\end{array}$} & San José & -78 & -2.6 & -13 & -65 & $-13,849$ & -2.8 & 229 & $-14,078$ \\
\hline & Heredia & 6 & 2.1 & 5 & 1 & 4,442 & 5.4 & $-2,265$ & 6,707 \\
\hline & Cartago & 28 & 36.8 & 8 & 20 & 2,874 & 3.9 & 644 & 2,230 \\
\hline \multirow{3}{*}{$\begin{array}{l}\text { Ecuador, } \\
2001\end{array}$} & Quito & 5,005 & 28.6 & -592 & 5,597 & 18,198 & 3.0 & $-29,157$ & 47,355 \\
\hline & Guayaquil & 3,068 & 23.9 & 31 & 3,037 & 41,068 & 4.3 & 11,609 & 29,459 \\
\hline & Cuenca & 714 & 49.1 & 147 & 567 & 11,322 & 9.4 & 2,968 & 8,354 \\
\hline \multirow{3}{*}{$\begin{array}{l}\text { Guatemala, } \\
2002\end{array}$} & Guatemala City & 10,666 & 14.4 & $-3,028$ & 13,694 & 489 & 0.1 & $-28,459$ & 28,948 \\
\hline & Quetzaltenango & 1,007 & 3.8 & 681 & 326 & 98 & 0.4 & 216 & -118 \\
\hline & Escuintla & -152 & -6.7 & -9 & -143 & $-2,556$ & -5.2 & -561 & $-1,995$ \\
\hline \multirow{3}{*}{$\begin{array}{l}\text { Honduras, } \\
2001\end{array}$} & Tegucigalpa & -219 & -12.7 & -32 & -187 & 11,671 & 3.2 & 1,218 & 10,453 \\
\hline & San Pedro Sula & 181 & 3.7 & -42 & 223 & 6,708 & 3.1 & $-11,439$ & 18,147 \\
\hline & La Ceiba & 258 & 6.7 & -10 & 268 & 1,089 & 2.1 & 203 & 886 \\
\hline \multirow[t]{3}{*}{ Mexico, 2000} & Mexico City & 1,137 & 1.7 & 1,226 & -89 & $-72,063$ & -1.0 & 17,596 & $-89,659$ \\
\hline & Guadalajara & 41 & 1.1 & -46 & 87 & $-14,719$ & -1.0 & $-8,256$ & $-6,463$ \\
\hline & Monterrey & 1,965 & 52.9 & -2 & 1,967 & 40,656 & 3.0 & -148 & 40,804 \\
\hline \multirow{3}{*}{$\begin{array}{l}\text { Panama, } \\
2000\end{array}$} & Panama City & 8,101 & 67.7 & 161 & 7,940 & 74,220 & 14.5 & 5,979 & 68,241 \\
\hline & Colón & 270 & 17.3 & 8 & 262 & 1,499 & 2.1 & 2,105 & -606 \\
\hline & David & 651 & 62.2 & 287 & 364 & 266 & 0.5 & 5,402 & $-5,136$ \\
\hline \multirow{3}{*}{$\begin{array}{l}\text { Paraguay, } \\
2002\end{array}$} & Asunción & -219 & -12.7 & -32 & -187 & 11,671 & 3.2 & 1,218 & 10,453 \\
\hline & Ciudad del Este & 88 & 200.0 & 11 & 77 & $-2,257$ & -2.4 & $-1,861$ & -396 \\
\hline & Encarnación & 4 & 20.0 & -2 & 6 & $-3,592$ & -8.7 & $-1,213$ & $-2,379$ \\
\hline
\end{tabular}

Source: Latin American and Caribbean Demographic Centre (CELADE) - Population Division of ECLAC, special processing of census microdatabases. 


\subsubsection{Are indigenous people more likely to return?}

Table 11 makes it possible to provide a direct answer to this hypothesis that is ubiquitous in the literature, although rarely analysed with generalizable evidence. The table also provides an additional perspective on the theory of greater territorial fixation among indigenous people, as it combines recent migration with lifetime migration. Table 11 shows that returning to the minor administrative division of birth is uncommon, with no signs of it being more common among indigenous people: a higher proportion of returning migrants among indigenous peoples was recorded in only three of the nine countries in question (Chile, Guatemala and Paraguay).

In terms of territorial fixation, the results in table 11 confirm and consolidate the finding on the lower propensity to migrate among indigenous people, with non-migrants at the level of minor administrative divisions representing as much as $90 \%$ of the population in countries such as Mexico, Honduras and Guatemala. Although a certain proportion of that $90 \%$ of the population may have migrated without such flows being captured by the questions asked, this is also a demonstration of high territorial fixation indices, which can only be partially attributed to exogenous factors (as discussed above). However, this picture of greater territorial fixation fades somewhat when we take into account levels of recent migration, for which indigenous people have higher indices than non-indigenous groups in at least three countries (Bolivia, Chile and Panama). In other words, in the last few years of the 1990s, there seems to have been an upturn in migration among indigenous people, which could mean that their propensity to migrate will reach levels similar to those of non-indigenous people.

Table 11

MIGRATION TYPOLOGY COMBINING RECENT AND ABSOLUTE MIGRATION AT THE LEVEL OF MINOR ADMINISTRATIVE DIVISIONS, BY ETHNIC IDENTITY

\begin{tabular}{l|l|r|c|c|c|c|c}
\hline \multicolumn{1}{c|}{ Country } & Ethnic identity & $\begin{array}{c}\text { Old direct } \\
\text { migrants }\end{array}$ & $\begin{array}{c}\text { Recent } \\
\text { direct } \\
\text { migrants }\end{array}$ & $\begin{array}{c}\text { Multiple } \\
\text { migrants }\end{array}$ & $\begin{array}{c}\text { Return } \\
\text { migrants }\end{array}$ & $\begin{array}{c}\text { Non- } \\
\text { migrants }\end{array}$ & Total \\
\hline Bolivia, 2001 & Indigenous & 19.9 & 5.4 & 2.2 & 1.7 & 70.7 & 100 \\
& Non-indigenous & 21.7 & 5.3 & 2.3 & 2.0 & 68.7 & 100 \\
\hline Chile, 2002 & Indigenous & 31.8 & 6.3 & 7.2 & 2.3 & 52.4 & 100 \\
& Non-indigenous & 38.0 & 5.9 & 8.0 & 2.0 & 46.0 & 100 \\
\hline Costa Rica, 2000 & Indigenous & 16.0 & 3.5 & 2.5 & 1.1 & 76.8 & 100 \\
& Non-indigenous & 28.7 & 4.5 & 4.3 & 1.5 & 61.0 & 100 \\
\hline Ecuador, 2001 & Indigenous & 14.5 & 4.3 & 1.5 & 0.7 & 79.0 & 100 \\
& Non-indigenous & 28.0 & 4.7 & 3.1 & 1.1 & 63.1 & 100 \\
\hline Guatemala, 2002 & Indigenous & 8.9 & 2.5 & 0.9 & 2.2 & 85.5 & 100 \\
& Non-indigenous & 21.9 & 4.2 & 2.2 & 1.5 & 70.2 & 100 \\
\hline Mexico, 2000 & Indigenous & 6.3 & 1.8 & 0.4 & 0.7 & 90.9 & 100 \\
& Non-indigenous & 17.3 & 2.7 & 0.9 & 1.0 & 78.2 & 100 \\
\hline Honduras, 2000 & Indigenous & 9.5 & 2.0 & 0.6 & 0.5 & 87.3 & 100 \\
& Non-indigenous & 21.4 & 3.8 & 1.6 & 0.8 & 72.4 & 100 \\
\hline Panama, 2000 & Indigenous & 15.4 & 9.6 & 1.8 & 0.3 & 72.9 & 100 \\
& Non-indigenous & 25.2 & 9.4 & 2.4 & 0.8 & 62.2 & 100 \\
\hline Paraguay, 2002 & Indigenous & 17.4 & 3.8 & 1.7 & 1.7 & 75.5 & 100 \\
& Non-indigenous & 28.6 & 5.5 & 4.4 & 1.6 & 59.8 & 100 \\
\hline
\end{tabular}

Source: Latin American and Caribbean Demographic Centre (CELADE) - Population Division of ECLAC, special processing of census microdatabases. 


\subsubsection{How do indigenous people fare when they migrate from rural to urban areas?}

The final question of this study has to do with the outcome of migration. For many reasons of methodology, this is a difficult issue to address (Greenwood, 1997; Lucas, 1992). Nonetheless, some attempt will be made to respond based on the labour income of various types of rural-to-urban migrants, controlling for key exogenous factors such as education and domestic status (only heads of household considered, which also implies that age is partially controlled for).

For Brazil, the data in table 12 (concerning only indigenous people) show the suitability of the income variable, as it tends to increase systematically in line with education (with an income for highly educated indigenous people that is on average 10 times higher than that of uneducated individuals). A comparison of migrants and non-migrants then reveals the following: (a) migrants tend to have higher incomes than non-migrants, which is reflected in higher incomes for urban migrants (even when education is controlled for); (b) the "income boosting" effect of migration depends on the type of migration, as some types of flow have limited effects (such as migration between rural areas); (c) moving from the countryside to the city involves a significant increase in income, as those who have never migrated from the country receive an average of 134 reais, while those who migrate to urban areas receive over 300 reais; (d) the higher labour incomes of rural-tourban migrants is not due to an "educational composition effect", as controlling for schooling still leaves a significant gap between, on the one hand, those who have never or not recently migrated from the countryside and, on the other, people who have migrated from rural to urban areas in the last five years (irrespective of whether the migration is intra- or inter-municipal); (e) as a counterpoint to the previous point, a comparison between indigenous people who migrate from rural to urban areas and non-migrants in urban areas (or migrants between urban areas) shows that the latter have higher incomes, even after controlling for education.

Table 12

BRAZIL 2000: MONTHLY LABOUR INCOME OF HEADS OF HOUSEHOLD BY MIGRATORY STATUS AND YEARS OF SCHOOLING, SELECTED CATEGORIES (IN 2000 REAIS)

\begin{tabular}{|c|c|c|c|c|c|c|c|}
\hline \multirow[b]{2}{*}{$\begin{array}{l}\text { Type of urban and rural } \\
\text { migrant }(1995-2000)\end{array}$} & \multicolumn{7}{|c|}{ Indigenous } \\
\hline & Uneducated & $\begin{array}{c}1-3 \\
\text { years } \\
\text { education }\end{array}$ & \begin{tabular}{c|}
$4-7$ \\
years \\
education
\end{tabular} & \begin{tabular}{c|}
$8-10$ \\
years \\
education
\end{tabular} & $\begin{array}{c}11-14 \\
\text { years } \\
\text { education }\end{array}$ & $\begin{array}{c}15 \text { or more } \\
\text { years } \\
\text { education }\end{array}$ & Total \\
\hline Urban never migrated & 227 & 268 & 384 & 547 & 782 & 1799 & 520 \\
\hline Rural never migrated & 86 & 141 & 176 & 248 & 494 & 0 & 134 \\
\hline Urban non-migrant & 300 & 400 & 455 & 672 & 921 & 1826 & 609 \\
\hline $\begin{array}{l}\text { Urban (rural migrant from same } \\
\text { municipality) }\end{array}$ & 191 & 249 & 329 & 375 & 736 & 500 & 305 \\
\hline $\begin{array}{l}\text { Urban (urban migrant from other } \\
\text { municipality) }\end{array}$ & 295 & 346 & 418 & 694 & 1026 & 1690 & 640 \\
\hline $\begin{array}{l}\text { Urban (rural migrant from other } \\
\text { municipality) }\end{array}$ & 238 & 253 & 381 & 466 & 496 & 600 & 355 \\
\hline $\begin{array}{l}\text { Rural (urban migrant from same } \\
\text { municipality) }\end{array}$ & 330 & 300 & 220 & 380 & 425 & 1013 & 303 \\
\hline Rural non-migrant & 160 & 256 & 309 & 335 & 455 & 151 & 250 \\
\hline $\begin{array}{l}\text { Rural (urban migrant from other } \\
\text { municipality) }\end{array}$ & 216 & 221 & 383 & 324 & 1358 & 619 & 368 \\
\hline $\begin{array}{l}\text { Rural (rural migrant from other } \\
\text { municipality) }\end{array}$ & 135 & 143 & 216 & 181 & 490 & 200 & 174 \\
\hline $\begin{array}{l}\text { TOTAL (includes all } \\
\text { categories) }\end{array}$ & 151 & 260 & 370 & 591 & 863 & 1769 & 429 \\
\hline
\end{tabular}

Source: Latin American and Caribbean Demographic Centre (CELADE) - Population Division of ECLAC, special processing of census microdatabases. 
In the case of Panama (figure 2), the income variable is also highly appropriate as it systematically rises in line with education and, as expected, incomes are higher among nonindigenous people. A study of the link between migration and income reveals the following: (a) again, rural non-migrants in almost all educational categories have the lowest incomes; (b) those who leave the countryside have significantly higher incomes than those who remain in rural areas, even after controlling for education; (c) the income of indigenous people who migrate between rural areas is only slightly higher than those who remain in the same rural area, even after controlling for education; (d) urban non-migrants and those who migrate between urban areas have the highest incomes, among both indigenous and non-indigenous people and for almost all educational categories.

In summary, then, the data for Brazil and Panama suggest that the result (and maybe the original purpose) of the indigenous exodus from rural to urban areas is increased income, which will therefore encourage future migratory flows. Nevertheless, there are two factors that may serve to dissuade people from migrating and that should be examined in future studies. First, higher living costs in the city mean that larger incomes do not necessarily mean increased purchasing power. Second, the standing held by these migrants at destination (compared with urban non-migrants) implies a potential loss of status that affects the migrants themselves and the image they convey to those who remain in the countryside.

Figure 2

PANAMA: LABOUR INCOME OF HEADS OF HOUSEHOLD, BY RURAL-TO-URBAN MIGRATION STATUS (1995-2000), INDIGENOUS IDENTITY AND LEVEL OF EDUCATION

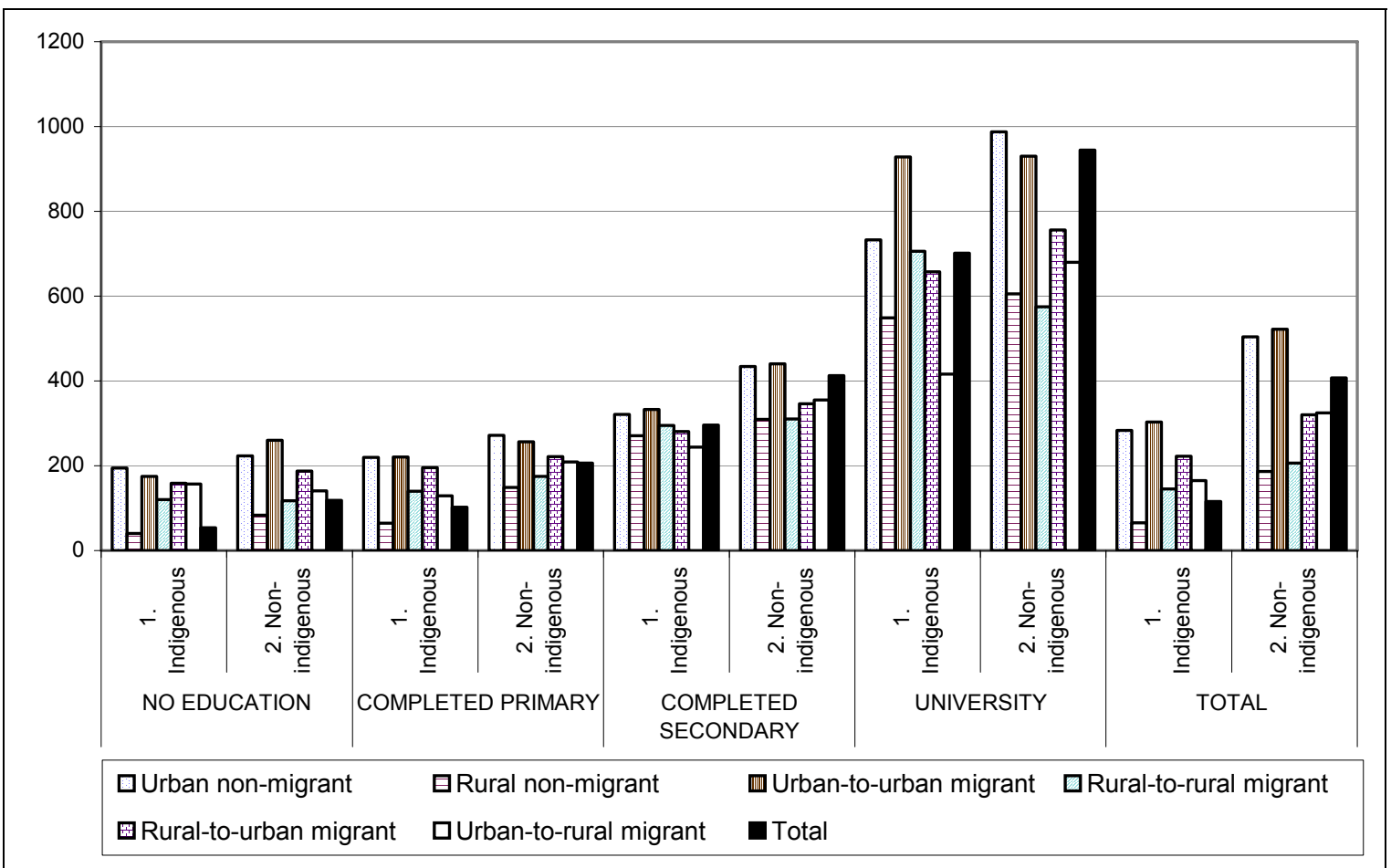

Source: Latin American and Caribbean Demographic Centre (CELADE) - Population Division of ECLAC, special processing of census microdatabases. 


\section{Conclusion}

Following on from this study, the necessary methodological and technological conditions are in place to step up the use of census microdatabases in order to partially alleviate the chronic shortage of information on indigenous migration. This study processed census microdatabases to empirically contrast several hypotheses on topical issues within the literature. The results had varying effects on these hypotheses. Some were backed up: such as the lower propensity to migrate among indigenous people (which, albeit applicable after controlling for exogenous factors, cannot be considered universal as it is not true in all countries), the net out-migration of indigenous people from rural areas and the variety of patterns among indigenous peoples. Others were rejected, such as the increased likelihood of return migration among indigenous people. Other hypotheses were expanded, like those concerning migratory selectivity and areas of origin and destination. The results also provided fresh evidence on the flows of indigenous people to and from main cities and the labour income of heads of household revealed information on the incorporation of indigenous migrants in urban and rural areas at destination.

Many of the findings are new and thought-provoking, but are far from being definitive. There are qualitative limitations on information based on the processing of census microdatabases, and the analyses remain fairly general. The next step is therefore for other more focused and detailed quantitative and qualitative studies to be carried out in order to examine the realities of specific local areas or indigenous peoples.

Perhaps the most significant finding is that indigenous people have strong incentives to migrate to cities, and the fact that they have been making that move in recent years will only serve to strengthen the networks that feed back into more migration. The downside is that indigenous people have a lower status in cities, and costs are higher than in their places of origin. As was the case with poor peasants, it is difficult to imagine a static situation for indigenous people, and we must assume that the displacement will continue. In terms of policy-making, the main challenges are to: (a) maximize the positive impact of migration for those indigenous people who choose that path; (b) use migratory flows creatively to strengthen cultures of origin, while preventing a "cultural lockdown" from blocking out the culture of the destination; (c) stamp out those forces that generate forced displacement from places of origin (especially rural areas); (d) ensure that the drain of relatively skilled people in the prime of their working life does not result in a serious deterioration of the communities of origin in rural areas; and (e) take advantage of migration as a source of resources and ties for precisely those communities that remain in the ancestral territories.

\section{Bibliography}

Bastos, Santiago (1999), "Migración y diferenciación étnica en Guatemala. Ser indígena en un contexto de globalización”, Papeles de población series № 002, Mexico City, Universidad Autónoma del Estado de México.

Bello, Álvaro (2004), "Etnicidad y ciudadanía en América Latina. La acción colectiva de los pueblos indígenas", Libros de la CEPAL No 79 (LC/G.2230-P), Santiago, Chile, Economic Commission for Latin America and the Caribbean (ECLAC). United Nations publication, Sales N $\mathrm{N}^{\circ}$ S.04.II.G.113.

Cardona, R. and A. Simmons (1975), "Hacia un modelo general de la migración interna en América Latina", América Latina. Distribución espacial de la población, Bogotá, D.C., Corporación Centro Regional de Población (CCRP).

CELADE (Latin American and Caribbean Demographic Centre-Population Division of ECLAC) (2006), "Pueblos indígenas y afrodescendientes de América Latina y el Caribe: información sociodemográfica para políticas y programas", Project documents $\mathrm{N}^{\circ} 72$ (LC/W.72), Santiago, Chile, Economic Commission for Latin America and the Caribbean (ECLAC).

Chant, S. (1999), "Population, migration, employment and gender", Latin America Transformed: Globalization and Modernity, R. Gwynne and C. Kay (eds.), London, Arnold. 
Del Popolo, Fabiana and Ana María Oyarce (2005), “América Latina, población indígena: perfil sociodemográfico en el marco de la Conferencia Internacional sobre Población y Desarrollo y de las metas del Milenio", Notas de población No 79 (LC/G.2284-P), Santiago, Chile, Economic Commission for Latin America and the Caribbean (ECLAC), June. United Nations publication, Sales $\mathrm{N}^{\mathrm{o}}$ S.05.II.G.141.

Delaunay, Daniel (2003), "Identidades demográficas del poblamiento y de los pueblos indígenas: un análisis contextual", Las dinámicas de la población indígena. Cuestiones y debates actuales en México, Mexico City, Centre for Research and Higher Learning in Social Anthropology (CIESAS)/Research Institute for Development (IRD).

Greenwood, M. (1997), "Internal migration in developed countries", Handbook of Families and Population Economics, M. Rosenzweig y O. Stark (eds.), Amsterdam, Elsevier.

IDB/ECLAC (Inter-American Development Bank/Economic Commission for Latin America and the Caribbean) (2005a), "Los pueblos indígenas de Bolivia: diagnóstico sociodemográfico a partir del censo del 2001", Project documents No 24 (LC/W.24), Santiago, Chile, Economic Commission for Latin America and the Caribbean (ECLAC).

(2005b), "Población indígena y afroecuatoriana en Ecuador: diagnóstico sociodemográfico a partir del censo de 2001", Project documents No 16 (LC/W.16), Santiago, Chile, Economic Commission for Latin America and the Caribbean (ECLAC).

(2005c), "Los pueblos indígenas de Panamá: diagnóstico sociodemográfico a partir del censo del 2000", Project documents N 20 (LC/W.20), Santiago, Chile, Economic Commission for Latin America and the Caribbean (ECLAC).

ILO (International Labour Organization) (2006), "Indigenous and tribal peoples migration. Notes by the International Labour Office" [online] http://www.un.org/esa/socdev/unpfii/documents/ workshop_ipm_ilo.pdf

INI (National Institute of Indigenous Affairs) (2000), Estado del desarrollo económico y social de los pueblos indígenas de México, 1996-1997, vol. 1, Mexico City, United Nations Development Programme (UNDP).

Lucas, R. (1997), "Internal migration in developing countries", Handbook of Population and Family Economics, M. Rozenweig y O. Stark (eds.), Amsterdam, Elsevier.

Murdock, G. (1967), Ethnographic Atlas, Pittsburgh, University of Pittsburgh Press.

Pérez Brignoli, Héctor (2005), "La dinámica demográfica de las poblaciones indígenas del trópico húmedo en América Central (censos 2000)", document presented at the twenty-fifth International Population Conference of the International Union for the Scientific Study of Population (IUSSP), Tours, 18-23 July.

Peyser, Alexia and Juan Chakiel (1994), "La población indígena en los censos de América Latina", Estudio sociodemográfico de los pueblos indígenas, series E No 40 (LC/DEM/G.146), Santiago, Chile, Economic Commission for Latin America and the Caribbean/Latin American Demographic Centre (CELADE)/Confederación de Pueblos Indígenas de Bolivia/United Nations Population Fund/IberoAmerican Cooperation Institute (ECLAC/CELADE/CIDOB/UNFPA/ICI).

Rodríguez, Jorge (2004), "Migración interna en América Latina y el Caribe: estudio regional del período 1980-2000”, Población y desarrollo № 50 (LC/L.2059-P), Santiago, Chile, Economic Commission for Latin America and the Caribbean (ECLAC), January. United Nations publication, Sales No S.04.II.G.3.

UNPFII (Permanent Forum on Indigenous Issues) (2006), Report of an Expert Workshop on Indigenous Peoples and Migration: Challenges and Opportunities (E/C.19/2006/CRP.5), May [online] http://www.un.org/esa/socdev/unpfii/documents/5session_crp5_migration.doc .

Villa, Miguel (1991), Introducción al análisis de la migración. Apuntes de clase, notas preliminares, series B $\mathrm{N}^{\circ} 91$ (LC/DEM/R.164), Santiago, Chile, Latin American and Caribbean Demographic Centre (CELADE).

Welti, Carlos (ed.) (1997), Demografia I, Latin American Programme of Population Activities (PROLAP). 



\section{Living conditions of urban indigenous people in the context of the millennium development goals}

Fabiana Del Popolo, Ana María Oyarce and Bruno Ribotta

\section{Introduction and objective}

The new challenge for governments is to design and implement public policies that promote, guarantee and allow compliance with international standards of indigenous peoples' rights. These rights go beyond rural-urban division; for this reason, the data presented here cover both areas, not only in order to quantify geographical gaps, but also on the understanding that urban indigenous groups are part of a unit, peoples who have collective rights.

This rights-based perspective involves a re-reading of equity gaps, as poverty, marginality and social exclusion, which affect a relatively larger proportion of these persons, are a violation of their human rights (ECLAC, 2006a). The follow-up and evaluation of these standards requires the production of public information, statistics, and systems of indicators that are reliable, timely and culturally relevant. 
In this context, the overall objective of this document is to describe the living conditions of Latin American indigenous peoples in an urban context, based on the censuses of the 2000 round. As the nations of the world have committed themselves to improving human well-being on the planet by signing the Millennium Declaration (New York, September 2000), this overview is offered in the context of the Millennium Development Goals (the Goals) which were derived from that Declaration.

\section{Methodological considerations}

As almost all the Latin American countries included a question on ethnic identity in their most recent population censuses, a partial assessment can be made of the situation of indigenous peoples in relation to the Millenium Development Goals (MDG's), especially those relating to education, health and the environment. For this paper, census microdata from the 2000 round were processed and this data source was used to calculate, where feasible, the indicators proposed for monitoring achievement of the targets for gender equality in access to education, completion of primary education, infant mortality rates and access to basic services (water and sanitation). ${ }^{42}$

In all cases the principle of self-identification was applied at the individual level, except when processing data on access to drinking water and sanitation. In this case the reference unit was the population of a dwelling unit irrespective of whether the head of household was recorded as indigenous or non-indigenous.

To ensure that indicators on primary and secondary education were comparable, the International Standard Classification of Education (ISCED 1997) of the United Nations Educational, Scientific and Cultural Organization (UNESCO) was used. This indicator is based on years of education completed. The infant and childhood mortality figures were obtained using an indirect estimate method based on the numbers of children born and deceased of mothers of fertile age. ${ }^{43}$

The coverage of access to drinking water and the availability of efficient sanitation follows the methodology proposed by CELADE for calculating unmet basic needs (UBN), which is based on national definitions. The criteria may differ from one country to another, which affects the comparability of the data. For the drinking water indicator, the availability of supply and type of installation are generally considered. As for sanitation, the presence of sanitation services and their exclusivity is considered. In urban areas, there is also the requirement of a sewer system, which excludes simple pit latrine systems.

As for interpretation of the indicators, they have been defined on the basis of the Western concept of development, without the participation of indigenous peoples. This means that the MDG's cannot include or reflect the specific needs and concerns of indigenous peoples. Moreover, as indicated in the report of the International Expert Group Meeting on the Millennium Development Goals, Indigenous Participation and Good Governance, organized by the United Nations Permanent Forum on Indigenous Issues (UNPFII) in January 2006: "the Millennium Development Goals do not take into account alternative ways of life and their importance to indigenous peoples, not only in the economic sense, but also as the underpinnings for social solidarity and cultural identity." At the same meeting it was recognized that the challenge is twofold: "On the one hand, they have the right to be fully included and to benefit from the global efforts to achieve the Millennium Development Goals, while on the other hand, their rights to define their own development path and priorities, must be respected, in order to ensure that the Millennium Development Goals contribute to the full realization and strengthening of the potential of these peoples". This is why it is essential for indigenous peoples to participate fully in the policies and programmes designed to achieve the Goals in the context of their rights (UNPFII, 2006).

42 The complete list of indicators proposed by the United Nations system can be seen at: http://unstats.un.org/ unsd/mdg/Host.aspx?Content=Indicators/OfficialList.htm

43 Brass method (United Nations, 1983). 
Without prejudice to the above, the indicators selected can be used to quantify equity gaps in formal education, mortality at early ages and access to basic services. These measurements are needed in order to monitor implementation gaps in relation to rights, although this is admittedly not sufficient for a holistic understanding of indigenous well-being based on collective rights.

\section{Census results and analysis}

\subsection{Formal education: Is access improving for indigenous persons in rural areas? Do ethnic and gender gaps still exist in cities? Are native languages being maintained?}

Education must be universal in order to achieve one of its basic objectives: to contribute to the creation of equality of opportunities for all citizens (UNESCO, 2004). There is a broad consensus that education is a key factor in human development and the second Millennium Development Goal relating to achieving universal primary education (by 2015) certainly also applies to indigenous peoples. Nevertheless, the quality of education must be considered in terms of the right to cultural integrity.

The third Goal is to promote gender equality and empower women, and the associated target is to eliminate gender disparity in primary and secondary education, preferably by 2005 , and in all levels of education no later than 2015. Although it does not take into account the set of skills and ancestral knowledge of indigenous peoples, formal education is especially significant in urban areas as educational level is a determining factor in labour market integration; ethnic gaps in formal education lead to inequality in employment opportunities.

Figure 1 shows school attendance rates for indigenous and non-indigenous children aged from 6 to 11 years by area of residence. It is seen that in urban areas indigenous boys and girls have systematically higher rates of access to primary education than those in rural areas and the figures reach $90 \%$ in most countries; the lowest coverage is in Paraguay, where 1 in every 3 indigenous children living in cities does not attend school. For indigenous people, the greatest urban-rural "gains" in school access are observed in Brazil, Costa Rica, Honduras and Paraguay.

Nevertheless, the data also show that gaps by ethnic status persist in urban areas, in all cases except in Bolivia and Honduras; the greatest ethnic differences are seen in the Bolivarian Republic of Venezuela and in Paraguay. In any case, inequalities to the disadvantage of the indigenous population are more pronounced in rural areas. The best situation in terms of ethnic equity and coverage and area of residence is found in Bolivia; the establishment of bilingual intercultural education (BIE) seems to have helped to reduce significantly the exclusion of the indigenous population from the education system, at least at the primary level (IDB/ECLAC, 2005a). 
PERCENTAGE OF GIRLS AND BOYS AGED 6 TO 11 YEARS WHO ATTEND PRIMARY SCHOOL, BY INDIGENOUS POPULATION AND AREA OF RESIDENCE, 2000 CENSUS ROUND

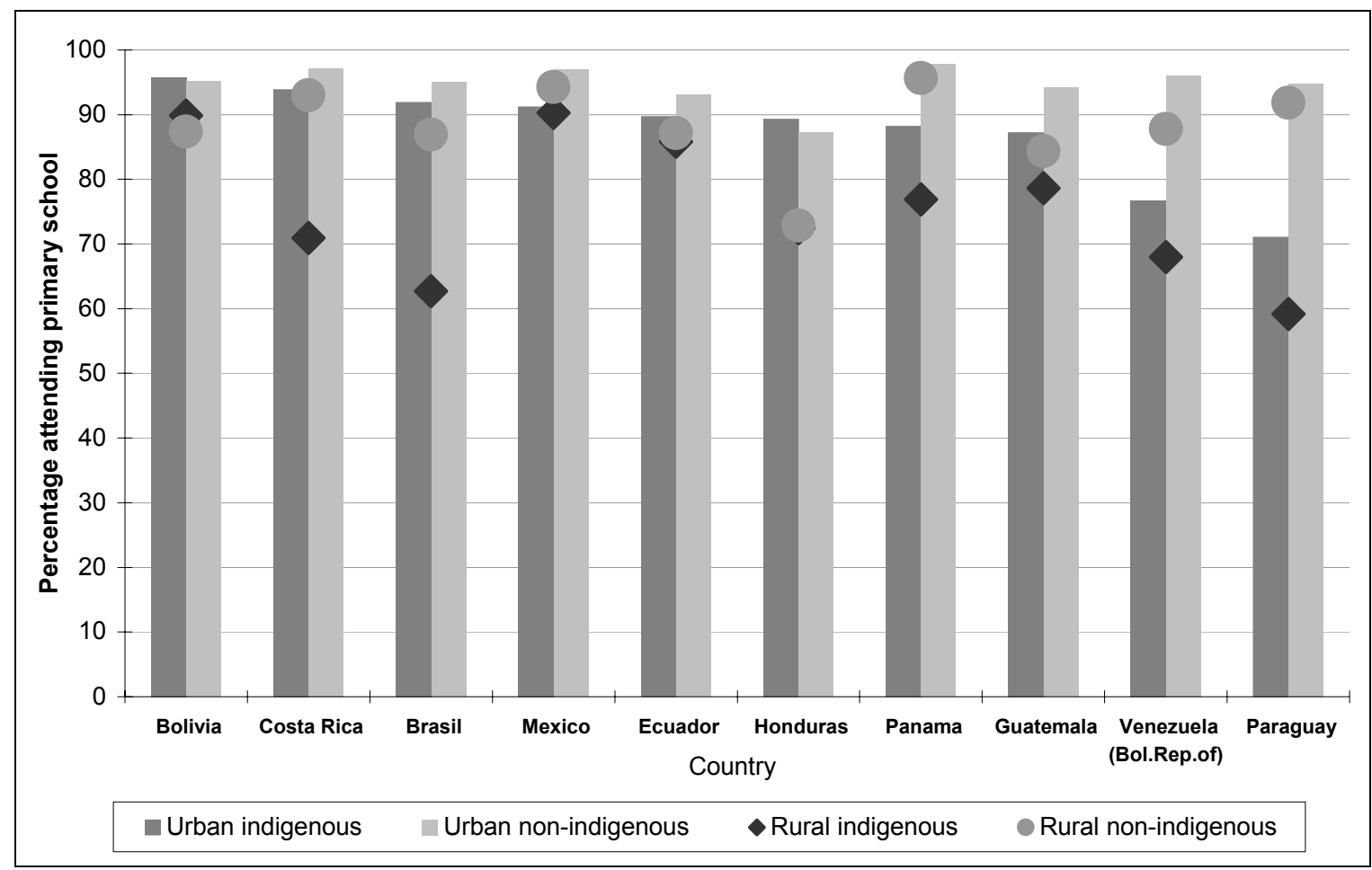

Source: annex table 1

Figure 2 shows that, in general, there are also gaps between indigenous and non-indigenous groups in cities with a high concentration of indigenous population. ${ }^{44}$ School coverage among indigenous people is similar to the urban average, except in San José (Costa Rica), San Pedro Sula (Honduras) and Maracaibo (Bolivarian Republic of Venezuela), where the situation is somewhat less favourable, as a larger proportion of indigenous children remain outside the formal education system compared to the average for urban indigenous people. These differences are linked to the diversity of situations of urban indigenous groups, as mentioned previously. It is also possible to find inequalities among indigenous peoples, even when the area of residence is controlled. For example, in the case of Bolivia, urban indigenous children belonging to the Aymara people have the highest school attendance rate $(96.3 \%)$ of all peoples (IDB/ECLAC, 2005a).

In the context of the Millennium Development Goals, the target refers to completion of primary education, and in this sense not all children who have access to it actually complete the cycle. In order to assess this fact, an analysis follows of a cohort close to the official age of primary education, whose members should have already completed that level. The percentage of young people aged 15 to 19 years who had completed primary education was calculated.

44 Note that the urban agglomerations with the largest indigenous populations are not necessarily the main metropolitan areas. For more details on territorial distribution of the indigenous population see the document prepared by Del Popolo for this same seminar. 
Figure 2

PERCENTAGE OF INDIGENOUS AND NON-INDIGENOUS CHILDREN AGED 6 TO 11 YEARS WHO ATTEND SCHOOL IN URBAN AGGLOMERATIONS WITH A HIGH CONCENTRATION OF INDIGENOUS POPULATION AND THE PERCENTAGE OF SCHOOL ATTENDANCE OF ALL URBAN INDIGENOUS CHILDREN FROM THE SAME AGE GROUP, 2000 CENSUSES

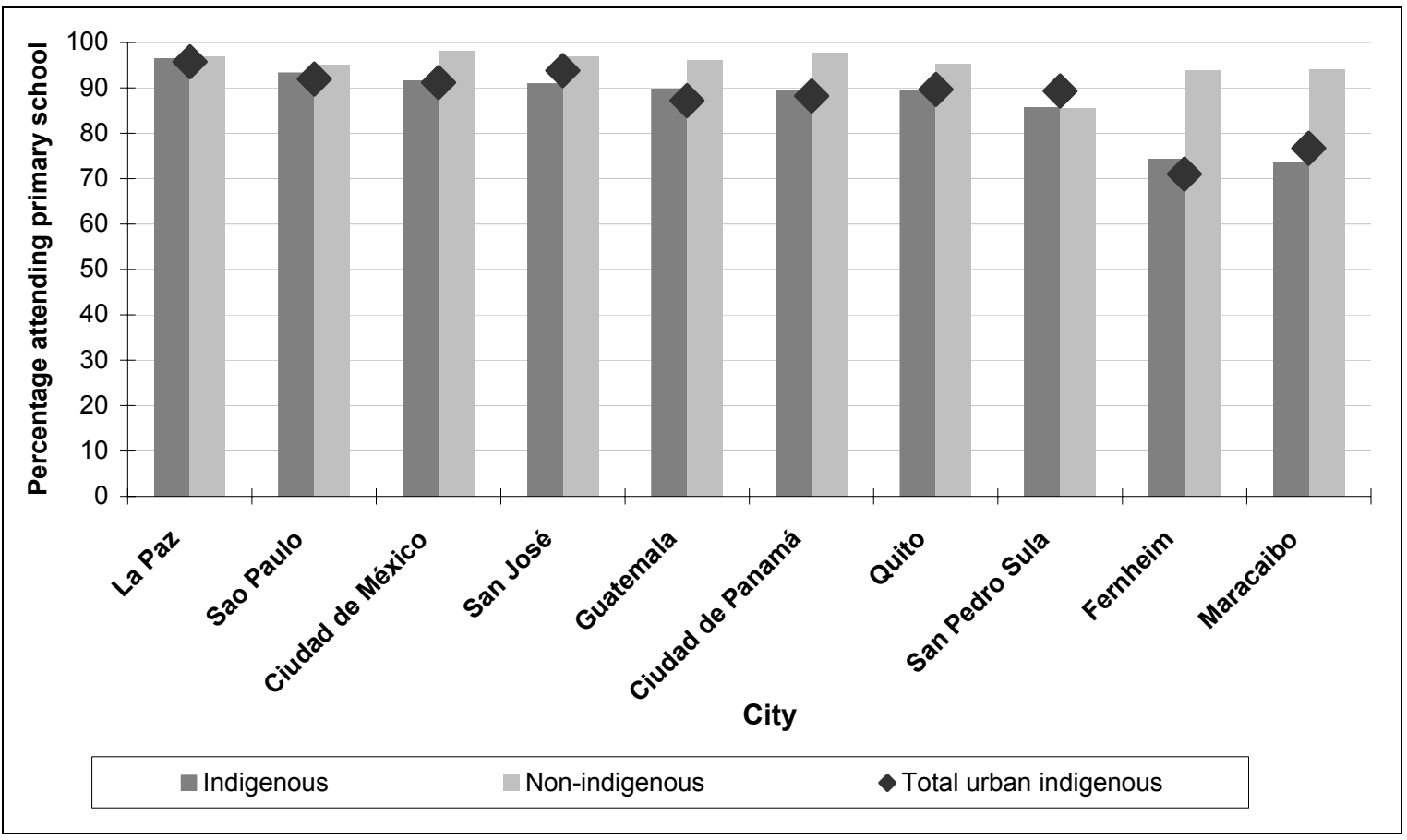

Source: annex table 2. BY INDIGENOUS POPULATION AND AREA OF RESIDENCE, 2000 CENSUSES

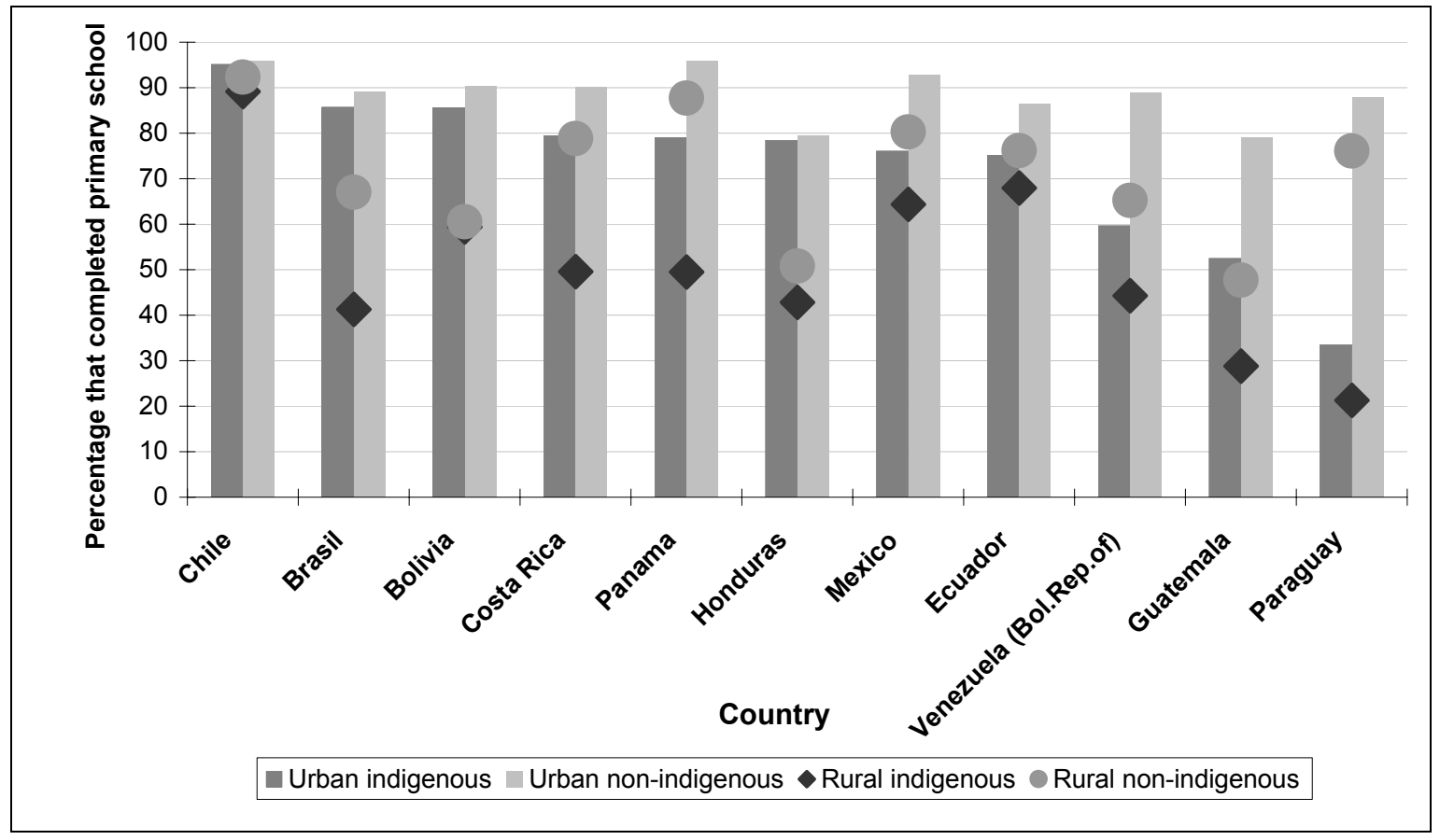

Source: annex table 1. 
Figure 3 shows that it is more feasible to achieve this target in urban rather than in rural areas, although ethnic disparities are increasing and becoming more widespread. In the case of young urban indigenous people aged 15 to 19 years, the proportion which has completed primary education ranges from $33.5 \%$ in Paraguay to $95.1 \%$ in Chile; in contrast, the rate for young urban non-indigenous people ranges from $79.2 \%$ in Guatemala to $96 \%$ in Chile and Panama. Only in Chile and Honduras are the urban areas close to reaching parity, while in Chile, completion of primary education is close to being universal. Furthermore, annex table 2 shows the completion rates for primary education in the cities with the highest concentration of indigenous people. In most cases, the situation of young indigenous people in these cities is better than the urban indigenous average (in 7 of the 11 urban agglomerations considered). In the other four cities the situation is the reverse, especially in Maracaibo, where the rate for completion of primary education by indigenous people aged 15 to 19 years is somewhat lower than the urban indigenous average; in the cases of Santiago, San José and Quito the differences are not significant.

As for gender differences, annex table 3 shows the sex ratio as the quotient of the rates for indigenous girls who attend school and the rates for indigenous boys (the same calculation is made for non-indigenous children). A value equal to 1 indicates equity between men and women. For indigenous children aged 6 to 11 years who reside in cities, gender gaps in access to primary education are minimal; the largest difference is in favour of urban indigenous girls in Paraguay, whose attendance rate is $6 \%$ higher than that of urban indigenous boys. Similar results are observed in the cities with the highest concentration of indigenous population (annex table 4), although the gender differences are slightly larger, in some cases in favour of indigenous girls and in other cases in favour of indigenous boys.

The higher the level of education, the greater the inequalities in access by ethnic status and gender (Del Popolo and Oyarce, 2005). School attendance by urban indigenous young people aged 12 to 17 years varies from $52 \%$ in Paraguay to $87 \%$ in Bolivia; for urban non-indigenous young people the values range from $70 \%$ in Honduras to $90 \%$ in Panama (ECLAC/Fund for the Development of the Indigenous Peoples of Latin America and the Caribbean, 2007). The sex differences in rates for secondary and higher levels are shown in figure 4, indicating that in some countries there is still much to be done in terms of achieving the gender equity targets. The national averages for Latin America show a favourable trend for women in education (although the resulting benefits are not yet apparent, for example, in labour income). This trend is less apparent among the indigenous population; in half of the countries for which information is available, secondary-level attendance rates in the cities are higher for young indigenous females, while in the other countries the situation is the opposite. In relation to higher education, gender gaps are mostly unfavourable to young urban indigenous females, in 6 of the 10 countries. In the other 4 countries, the situation is the opposite, especially in the urban areas of Honduras and the Bolivarian Republic of Venezuela, where there is more access to higher levels of formal education for indigenous females than for males. The pattern is similar in cities with a large concentration of indigenous population (annex table 4). 
RATIO OF FEMALE AND MALE RATES FOR ATTENDANCE AT SECONDARY AND HIGHER LEVELS OF EDUCATION IN URBAN AREAS, BY INDIGENOUS STATUS, 2000 CENSUSES

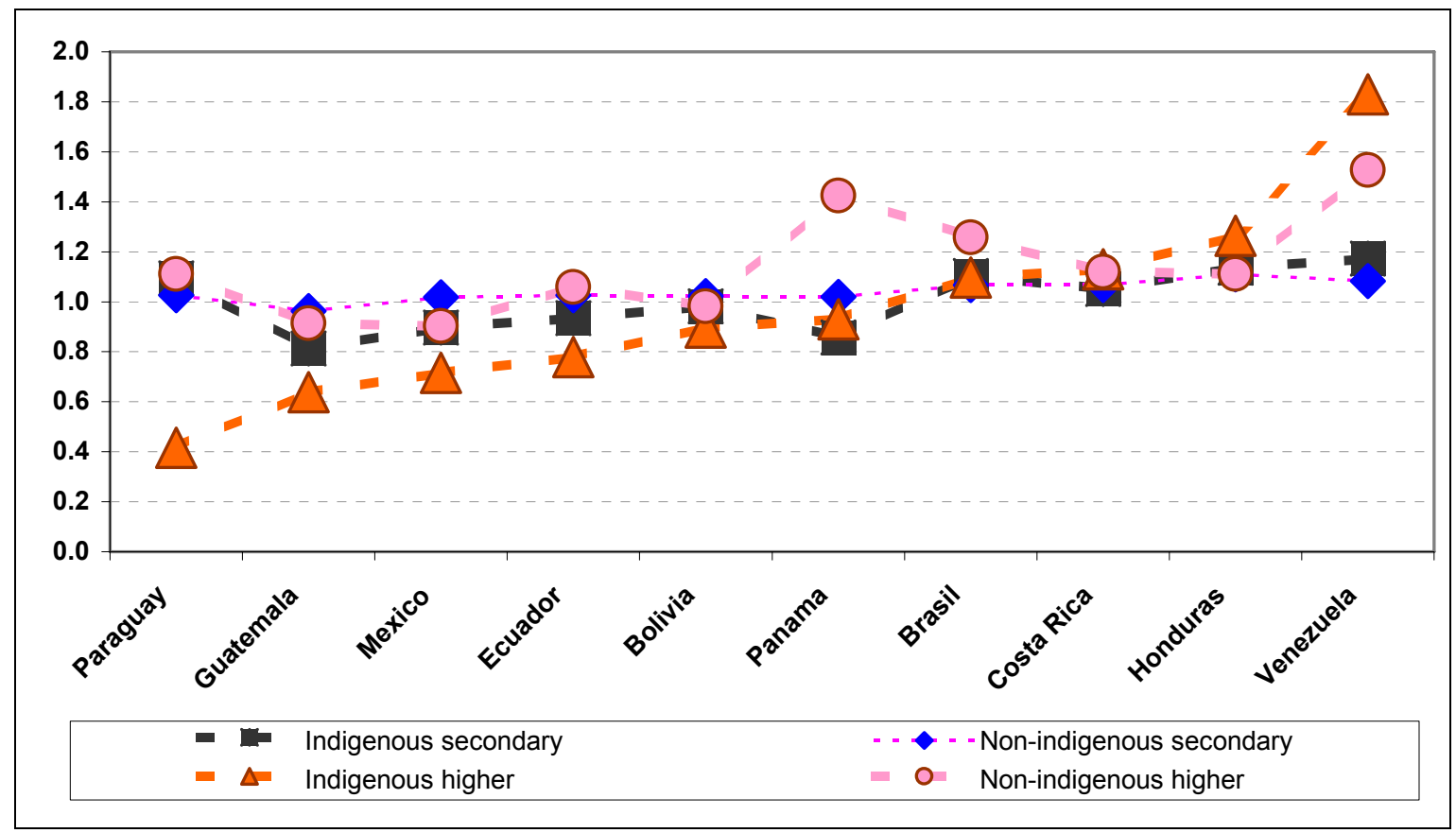

Source: annex table 3.

Access is only the starting point for educational equity and it is important to have highquality, efficient and relevant indicators for the educational system. Censuses can be used to calculate some complementary indicators such as under-attainment or the school drop-out rate (which is beyond the scope of this document). A study conducted in Bolivia based on the 2001 census analyses the education cycle of the cohort aged 20 to 24 years. It shows that in rural areas under-attainment and drop-out rates are higher than in urban areas for both indigenous and nonindigenous young people. Nevertheless, ethnic differences are relatively and significantly larger in urban areas to the disadvantage of indigenous young people (IDB/ECLAC, 2005a). In addition, an exploratory study carried out in Quito (Ecuador) shows that although indigenous people have less access to secondary education than non-indigenous people, when they do have access, indigenous people have a higher probability of entering university (León, 2003). Further and more extensive research is clearly needed to consider specific patterns in the region.

In terms of collective rights, the implementation gaps are even larger. Although in Latin America there are many bilingual intercultural education programmes designed for indigenous people, including those in Bolivia, Colombia, Ecuador, Guatemala, Mexico and Peru, the implementation processes for these programmes have been slow and complex. They also suffer from problems such as the lack of trained human resources, regular budgets and educational materials, and in particular the fact that the decision-making takes place without the participation of indigenous peoples. Nevertheless, it is important to highlight valuable experiences such as those in Ecuador and Peru, in which a crucial factor has been the engagement of an indigenous counterpart (ECLAC, 2006a). These experiences, however, have been mainly in rural areas. Discrimination and disdain for indigenous languages in urban areas lead to abandonment of the native language in the second and third generations of indigenous immigrants, as shown by research carried out in cities in Ecuador, Mexico and Peru (León, 2003; Molnar, Carrasco and Johns-Swartz, 2003; Vigo and Chávez, 2003). 
The contents of educational programmes in general do not encourage the kind of profound cultural changes that would bring respect for and appreciation of cultural diversity (Peredo Beltrán, 2004). Local studies show that indigenous parents and children perceive primary schools as places where indigenous identity is viewed as negative. Meanwhile, minimizing distinctive cultural features is perceived as beneficial for social advancement and countering discrimination (León, 2003; Molnar, Carrasco and Johns-Swartz, 2003; Vigo and Chávez, 2003). The first strategy consists in abandoning the native language or restricting its use to private gatherings (within the family, at religious celebrations and with indigenous peers), as clearly shown in figure 5.

On the one hand, the proportion of indigenous people in urban areas who speak their language is significantly less than in rural areas, except in Paraguay. On the other hand, the loss of the indigenous language is a generational process, especially in the cities. The results for Bolivia and Ecuador are dramatic, as less than $30 \%$ of young urban indigenous people (aged under 14 years) speak an indigenous language.

The case of Paraguay is a counter-example. Guaraní is an official language in the country and is spoken by most of the Paraguayan population. This means that there is no cultural discrimination against the indigenous language. In this context, no loss is taking place. Language loss is directly related to the pressure exercised by the dominant society and the educational environment. Nevertheless, the loss of a native language is not equivalent to the loss of indigenous identity.

Figure 5

PERCENTAGE OF INDIGENOUS PERSONS WHO SPEAK THE INDIGENOUS LANGUAGE, BY AGE AND AREA OF RESIDENCE, 2000 CENSUSES

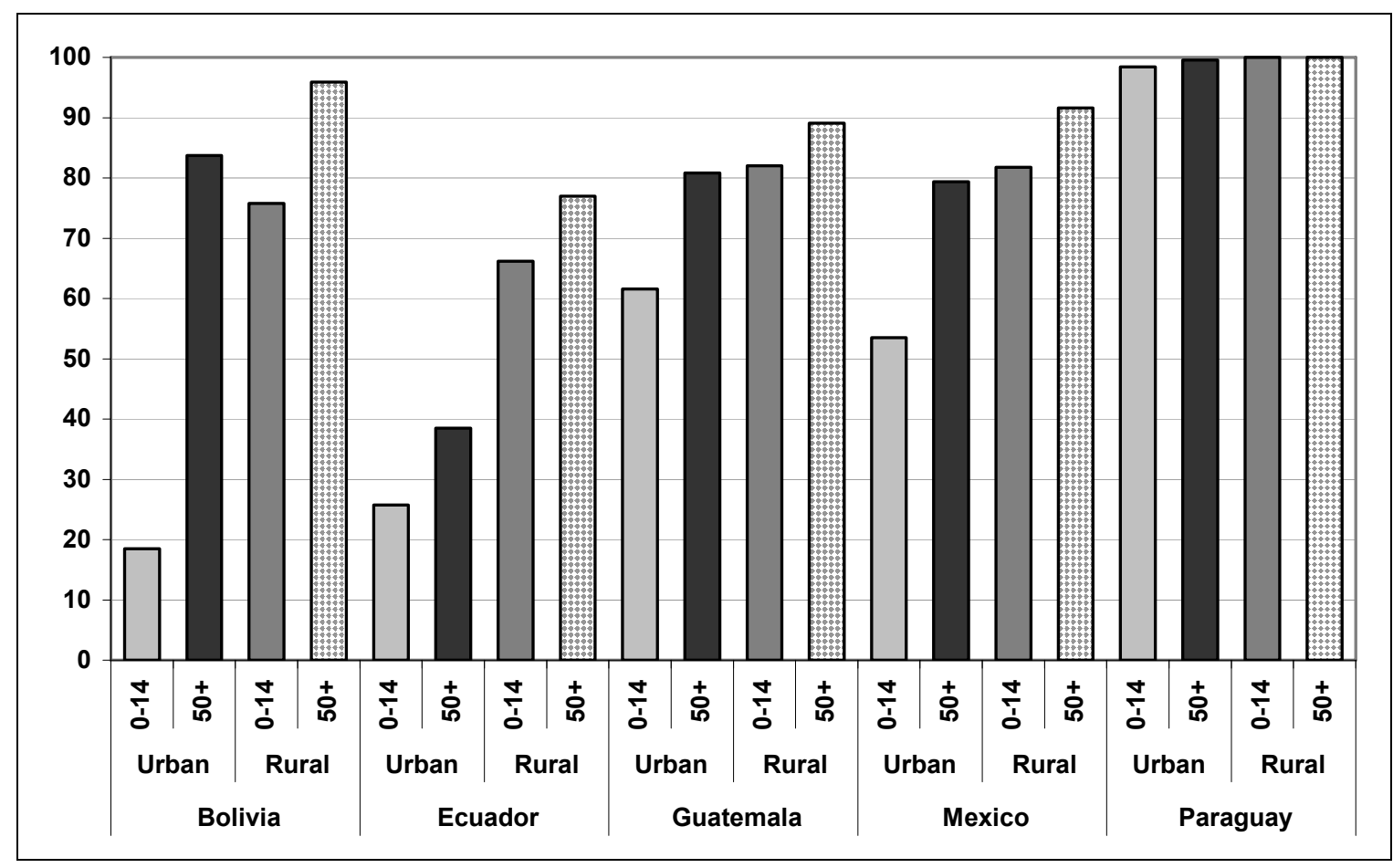

Source: Economic Commission for Latin America and the Caribbean (ECLAC)/ Fund for the Development of the Indigenous Peoples of Latin America and the Caribbean, System of Sociodemographic Indicators for Indigenous Peoples and Populations of Latin America (SISPPI), 2007. 


\subsection{Health in childhood: Is the risk of early death lower in cities? Are there still ethnic gaps?}

Early mortality is considered a sensitive indicator for assessing the quality of life and well-being of a population, as most early deaths are preventable under the proper economic, nutritional and health care conditions. From the human-rights perspective, it is an essential indicator for monitoring the exercise of the right to health. In view of the above, one of the priorities established in the Millennium Declaration is to improve maternal and child health of the world's populations. Accordingly, Goal 4 is to reduce child mortality and target 5 is to reduce by two-thirds, between 1990 and 2015, the under-five mortality rate (United Nations, 2000). ${ }^{45}$

In the regional context, early mortality has fallen steadily and rapidly over the past 40 years, from an infant mortality rate of 102 per thousand live births at the beginning of the 1960 s to 26 per thousand live births at present (ECLAC, 2006c). Normally, the poorest countries in the region tend to have the highest risks of early death and, despite the reduction in rates, there is a high degree of inequality between countries, areas and social groups (ECLAC, 2006c, 2006a).

There is an international consensus that compliance with Objetive 4 (MDG) will only be possible if inequities are reduced and if efforts are focused on reducing the rates of the most excluded and vulnerable groups, including indigenous peoples. In fact, although early mortality is associated with poverty and living in rural areas, inequalities between indigenous and non-indigenous people are still apparent when these factors are controlled (ECLAC, 2006a). Thus, the average infant mortality rate for indigenous children in Latin America is $60 \%$ higher than for non-indigenous children: 48 per 1,000 live births compared with 30 per 1,000 live births, respectively. In terms of the probability of dying before reaching the age of 5 , the gap is even wider with an excess mortality of $70 \%$. Moreover, recent studies show that the relative differences have not only continued, but have actually increased in some countries (Del Popolo and Oyarce, 2005; ECLAC, 2006a).

The following section provides a regional overview of mortality among children under five years of age in the indigenous population. Table 1 shows that in general terms the probability of dying before reaching the age of five years is less for children who live in cities than for those in the country, regardless of their ethnic status. Nevertheless it is a mixed picture with the probability of death varying more significantly among indigenous children than among non-indigenous children in the different countries; at one extreme are Paraguay and Bolivia with the highest probabilities of death in infancy and early childhood; at the other extreme are Chile and Costa Rica with the lowest risks.

Urban areas clearly have greater coverage in terms of State goods and services and this includes greater access to health centres, resulting in lower mortality levels. In this connection, it may be said that living conditions are more favourable for indigenous children who live in cities. ${ }^{46}$ Nevertheless, the gaps by ethnic status are systematic, showing that there is still excessive mortality for indigenous children when they live in urban areas. In Guatemala, Honduras, Brazil and Costa Rica, the relative differences are actually higher in urban areas than in rural areas.

These findings seem to confirm the situation of social exclusion and discrimination which has been described for indigenous people living in cities (León, 2003; Molnar, Carrasco and Johns-

45 Infant mortality (children less than one year old) is mainly related to biological factors relating to the mother and child, and medical care, especially professional delivery care. Early childhood mortality (in children under five years of age) is mainly associated with unfavourable social and environmental conditions.

46 Although those who migrate do so to improve their socioeconomic conditions, they are not the poorest members of the community, as migration is an undertaking that requires resources. Indigenous immigrants may previously have had better living conditions than the indigenous people who remain in their rural communities. 
Swartz, 2003; Vigo and Chávez, 2003). The spatio-territorial and sociocultural dimensions are clearly distinguishable in terms of the reproduction of inequity. In relation to the first dimension, and irrespective of whether they are residents or migrants, indigenous people tend to settle in precarious areas and deprived neighbourhoods where there are few or no health centres (Quesnel, 2006). Morevoer, the sociocultural dimension is reflected in the fact that existing health services are inappropriate in view of the imposition of the Western biomedical model on indigenous groups, the exclusive use of the official language and especially in discrimination and the unsuitable way in which the health services provided for these population groups are organized. ${ }^{47}$

Table 1 INFANT AND EARLY CHILDHOOD MORTALITY RATES FOR INDIGENOUS AND NON-INDIGENOUS CHILDREN BY AREA OF RESIDENCE, 2000 CENSUSES

\begin{tabular}{|c|c|c|c|c|c|c|}
\hline \multirow{2}{*}{ Countries } & \multicolumn{2}{|c|}{ Indigenous } & \multicolumn{2}{|c|}{ Non-indigenous } & \multicolumn{2}{|c|}{ Relative gap $^{a}$} \\
\hline & Urban & Rural & Urban & Rural & Urban & Rural \\
\hline \multicolumn{7}{|c|}{ Child mortality (per 1,000 live births) } \\
\hline Bolivia & 63.3 & 85.5 & 50.5 & 60.2 & 1.25 & 1.42 \\
\hline Brazil & 37.2 & 41.8 & 31.4 & 43.0 & 1.18 & 0.97 \\
\hline Chile & 12.0 & 12.7 & 11.4 & 12.0 & 1.05 & 1.06 \\
\hline Costa Rica & 20.5 & 21.5 & 10.6 & 12.3 & 1.92 & 1.75 \\
\hline Ecuador & 39.1 & 73.8 & 24.6 & 37.9 & 1.59 & 1.95 \\
\hline Guatemala & 47.2 & 52.6 & 35.3 & 46.7 & 1.34 & 1.13 \\
\hline Honduras & 28.5 & 44.7 & 25.1 & 41.8 & 1.14 & 1.07 \\
\hline Mexico & 34.2 & 47.3 & 23.9 & 33.7 & 1.43 & 1.40 \\
\hline Panama & 31.6 & 57.4 & 15.7 & 19.5 & 2.01 & 2.94 \\
\hline Paraguay & 72.1 & 79.1 & 38.8 & 36.3 & 1.86 & 2.18 \\
\hline Bolivarian Republic of Venezuela & 33.3 & 60.5 & 19.0 & 23.6 & 1.75 & 0.80 \\
\hline \multicolumn{7}{|c|}{ Early childhood mortality (per 1,000 live births) } \\
\hline Bolivia & 81.0 & 113.1 & 62.9 & 76.6 & -1.29 & 1.48 \\
\hline Brazil & 46.6 & 53.1 & 38.6 & 54.9 & 1.21 & 0.97 \\
\hline Chile & 14.3 & 15.2 & 13.5 & 14.2 & 1.06 & 1.07 \\
\hline Costa Rica & 24.3 & 25.7 & 12.8 & 14.7 & 1.90 & 1.75 \\
\hline Ecuador & 49.5 & 103.3 & 30.3 & 47.8 & 1.63 & 2.16 \\
\hline Guatemala & 61.3 & 69.6 & 43.8 & 60.4 & 1.40 & 1.15 \\
\hline Honduras & 40.1 & 64.8 & 35.3 & 60.3 & 1.14 & 1.07 \\
\hline Mexico & 48.6 & 71.3 & 32.3 & 47.7 & 1.50 & 1.49 \\
\hline Panama & 38.2 & 79.7 & 17.0 & 21.7 & 2.24 & 3.68 \\
\hline Paraguay & 99.2 & 110.1 & 48.1 & 44.5 & -2.06 & 2.47 \\
\hline Bolivarian Republic of Venezuela & 52.0 & 104.2 & 27.9 & 35.2 & 1.86 & 2.96 \\
\hline
\end{tabular}

Source: Social Panorama of Latin America 2006, ECLAC.

${ }^{a}$ Quotient of indigenous and non-indigenous child mortality rates.

Table 2 shows the early childhood mortality rate for cities with larger indigenous populations; in 7 of $10^{48}$ there is excess mortality for young indigenous persons; with a high degree of rate variability that does not occur in the case of non-indigenous population. The highest risks are

47 A recent study of urban indigenous people in Peru shows that social exclusion in health is reflected in both a higher perception of illnesses, chronic diseases, accidents and symptoms and in lower percentages of medical service coverage than for non-indigenous people (León, 2003). In Guatemala, even when indigenous women are treated in hospitals and recognize that this option may be safer, the treatment is poor and the hours are restrictive and inconvenient (Enge, 1998).

48 It was not possible to calculate this indicator for Guatemala, as the information on the non-indigenous population was inconsistent. 
in Fernheim (Paraguay) with values exceeding 70 per 1,000 live births and La Paz (Bolivia) with 65 per 1,000 live births. The lowest rate is for indigenous children living in Santiago, Chile, with rates of 11 per 1,000 live births.

In terms of relative gaps, the greatest inequities between indigenous and non-indigenous population are found in the cities of Fernheim (Paraguay) where the probability of an indigenous child dying is almost three or four times greater than for a non-indigenous child and in San José (Costa Rica) where the risk is doubled for such children. ${ }^{49}$

In San José, La Paz and Mexico City, the early childhood mortality rates for indigenous people are higher than the urban national mortality rates for this group. The diversity of indigenous peoples and the different types of residents that inhabit the cities make it difficult to use this information to gain an understanding of the urban excess mortality; nevertheless the case of Costa Rica shows that low mortality for the country as a whole or even for one area such as the capital city does not necessarily imply a better situation for the indigenous population.

In fact, San José (as indeed Costa Rica as a whole) has one of the lowest early mortality rates in Latin America (around 10 per 1,000 live births) and one of the most efficient social security systems in the region, yet these benefits do not seem to reach indigenous children to the same extent. ${ }^{50}$

Table 2

INFANT AND UNDER-FIVE MORTALITY RATES FOR INDIGENOUS AND NON-INDIGENOUS CHILDREN IN CITIES WITH LARGE INDIGENOUS POPULATIONS, 2000 CENSUSES

\begin{tabular}{|c|c|c|c|c|c|c|}
\hline \multirow{2}{*}{ City } & \multicolumn{3}{|c|}{ Infant mortality rate } & \multicolumn{3}{|c|}{ Under-five mortality rate } \\
\hline & Indigenous & Non-indigenous & Relative gap $^{a}$ & Indigenous & Non-indigenous & Relative gap $^{a}$ \\
\hline La Paz & 64.7 & 48.9 & 1.32 & 92.1 & 68.1 & 1.35 \\
\hline Sao Paulo & 21.6 & 23.8 & 0.90 & 26.0 & 28.5 & 0.90 \\
\hline Santiago & 11.0 & 12.7 & 0.87 & 13.4 & 15.3 & 0.88 \\
\hline San José & 22.0 & 10.5 & 2.10 & 26.8 & 12.7 & 2.11 \\
\hline Quito & 37.9 & 22.6 & 1.68 & 46.5 & 27.1 & 1.72 \\
\hline Guatemala & 37.7 & & & 46.7 & & \\
\hline San Pedro Sula & 22.8 & 26.4 & 0.86 & 27.6 & 31.8 & 0.87 \\
\hline Mexico City & 34.9 & 25.7 & 1.36 & 45.0 & 31.0 & 1.45 \\
\hline Panama City & 25.2 & 14.9 & 1.69 & 31.3 & 17.4 & 1.80 \\
\hline Fernheim & 71.7 & 19.6 & 3.66 & 99.6 & 23.9 & 4.17 \\
\hline Maracaibo & 33.6 & 22.9 & 1.46 & 42.8 & 27.2 & 1.57 \\
\hline
\end{tabular}

Source: Latin American and Caribbean Demographic Centre (CELADE) - Population Division of ECLAC, special processing of census microdata.

${ }^{a}$ Quotient of indigenous and non-indigenous child mortality rates.

In addition to the diversity of situations across countries and cities, the pattern of infant mortality also varies among and within indigenous peoples. For example, the Mbya and Nivacle peoples in Paraguay and the Quechua in Bolivia have the highest probabilities of dying in infancy (figure 6). Conversely, the Mapuche and Atacamenian peoples in Chile show the lowest rates, with

49 The lower early mortality rates for indigenous children observed in Sao Paulo (Brazil) and San Pedro Sula (Honduras) may be partly due, to the fact that other ethnic groups, such as Afro-descendants, who may have higher rates are included in the non-indigenous category .

50 Recently, the Hospital Maximiliano Peralta de Cartago has implemented a number of initiatives to tackle the high infant mortality and undernutrition rates of Ngobe-Bugle immigrants, in order to provide more humane and comprehensive treatment (Calvo, 2006). 
11 and 12.5 per 1,000 live births. Both peoples are mostly settled in urban areas. ${ }^{51}$ The national context also affects infant mortality rates, as can be appreciated from the Quechua and Aymara peoples living in Bolivia and Chile. For a Quechua child in Bolivia the probability of dying before completing the first year of life is five times as high as for a Quechua child in Chile. The differential for Aymara children is a factor of four (see figure 6). ${ }^{52}$

Figure 6

INFANT MORTALITY RATES BY COUNTRY AND INDIGENOUS PEOPLES OR TERRITORY, 2000 CENSUSES

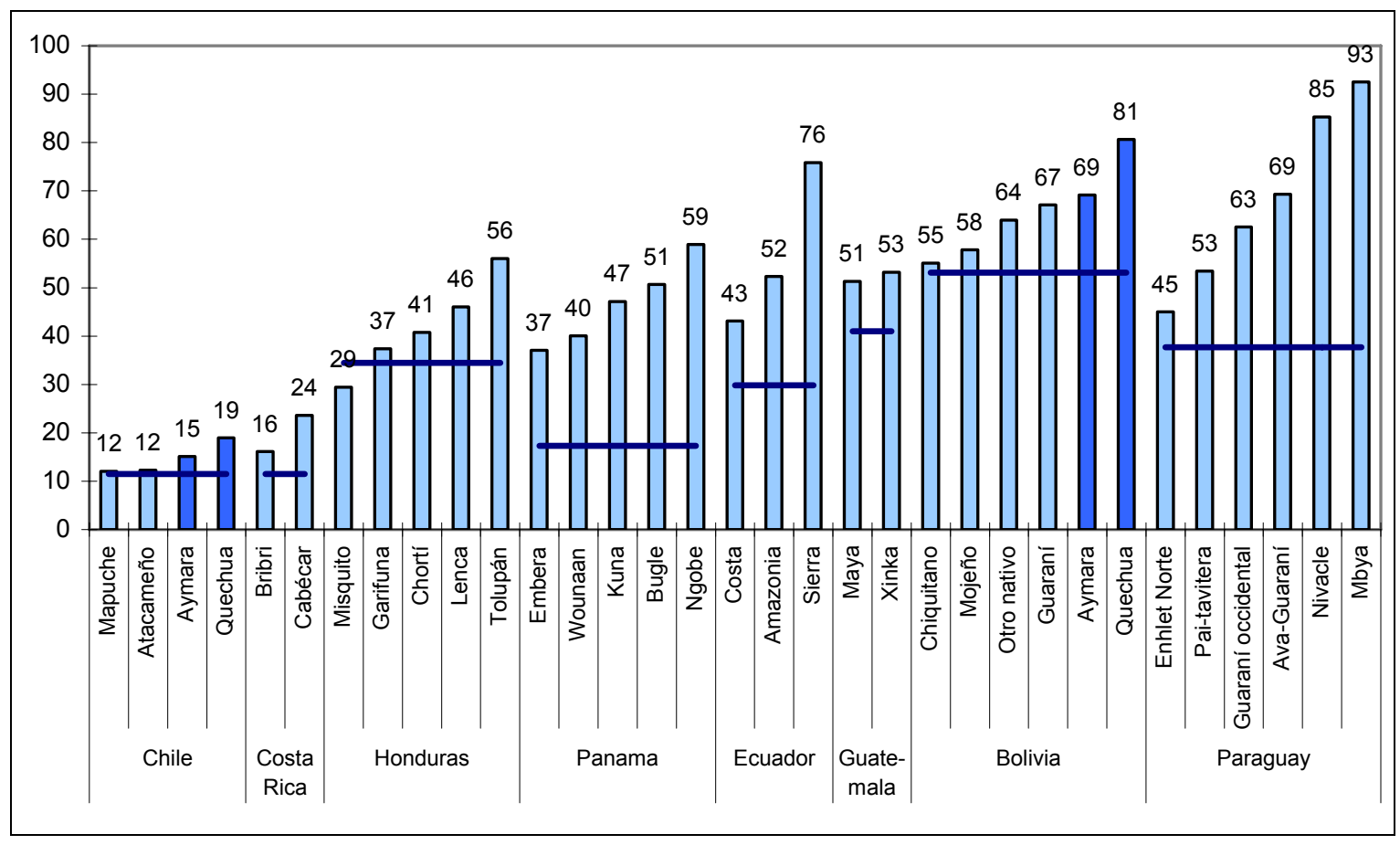

Source: Social Panorama of Latin America 2006, ECLAC.

51 One of the goals set forth in the Programme of Action of the International Conference on Population and Development and restated in 2004 by all the countries of the region was to bring the infant mortality rate below 50 per 1,000 live births by 2005. Over half of the indigenous peoples considered have rates higher than this figure (Del Popolo and Oyarce, 2006).

52 These differences are due not only to the structural conditions of the country of residence and access to services, but also to the history of contact with Western peoples and the destruction of ecosystems. Since the arrival of the conquistadors, the introduction of diseases to which the indigenous population had not previously been exposed has caused a massive demographic collapse (Kunitz, 1994; Montenegro and Stephens, 2006). For example, in the middle of the twentieth century in Brazil, around 60 Amazon groups disappeared. Demographic vulnerability is even greater for isolated and small peoples, where contagion with acute diseases can mean total destruction and this explains, in part, the decision of some peoples to remain as isolated as possible (Kunitz, 1994; Montenegro and Stephens, 2006). 


\subsection{Sustainability of the environment: Is the access of urban indigenous people to basic services improving? Are inequities being reduced?}

The seventh of the Goals deriving from the Millennium Declaration refers to ensuring environmental sustainability. It has three associated targets, which refer to both protection of the "natural" environment and improvement of the environment built by man. Target 9 refers to the first aspect, proposing integration of the principles of sustainable development into country policies and programmes and reversal of the loss of environmental resources. ${ }^{53}$ The subsequent targets refer to the second aspect of the environment: improvement in the provision of basic services and in living conditions in slums. More specifically, target 10 is to halve, by 2015, the proportion of people without sustainable access to safe drinking water and basic sanitation; and target 11 is, by 2020 , to have achieved a significant improvement in the lives of at least 100 million slum dwellers.

This document focuses on targets 10 and 11, and, in particular, on the indicators on sustainable access to an improved water source and improved sanitation services.

Access to basic services such as water and sanitation are closely related to exercising the right to life, as they directly affect the well-being and health of individuals and indirectly conservation of and respect for the environment. In contrast, the lack of these services is associated with poverty, morbidity and mortality and ecological damage (Cicowiez and others, 2006; IDB/ECLAC, 2005b; Rojas, 2006; Del Popolo and Oyarce, 2005; PAHO, 2004; Deruyttere, 1997; ECLAC-Fund for the Development of the Indigenous peoples of Latin America and the Caribbean, 2007).

From a non-monetary point of view, poverty may be interpreted as a lack of access to basic services, including the provision of drinking water and efficient sanitation services (Cicowiez and others, 2006). For indigenous peoples, this statement is particularly valid if one thinks of the structural role of discrimination and the inequality of opportunities which limit access to these and other benefits, such as education, medical and health care and urban infrastructure, or to the labour market, credit and technology (Busso, Cicowiez and Gasparini, 2005).

The lack or scarcity of water or its consumption in poor conditions, and the lack of basic sanitation, are a common cause of morbidity and mortality, especially in infants (Rojas, 2005; Busso, Cicowiez and Gasparini, 2005). In cities, the lack of these services, together with the lack of educational programmes to strengthen healthy habits, contribute significantly to the spread of diseases (PAHO, 2004). This situation can be even more serious for indigenous people, in view of a general lack of understanding of their ancestral practices and the lack of intercultural health policies and programmes.

Environmental deterioration is also related to inadequate access to water and inefficient sanitation services. Contamination of traditional water sources by the indiscriminate dumping of chemical and industrial wastes, or their disappearance owing to the alteration of ecosystems, has been denounced on many occasions by indigenous peoples (ECLAC-Fund for the Development of the Indigenous peoples of Latin America and the Caribbean, 2007), whose possibilities for maintaining and enhancing their living conditions are being restricted. In addition to the cultural and symbolic aspects of water conservation, the pressure on indigenous lands and associated resources has brought indigenous demands into line with those of environmental movements

53 Sustainable development is grounded in the recognition of the role played by the environment and natural resources in providing the material and environmental basis, the ecosystems and the energy on which economic processes depend (ECLAC, 2000; United Nations, 2005). It is made necessary by the global scale of mounting pressures on the environment, epitomized by problems such as global warning and the thinning of the ozone layer (United Nations, 2005). 
working for the preservation of biological diversity and the sustainable management of ecosystems (Deruyttere, 1997). ${ }^{54}$

In addition, the migration of indigenous people from rural to urban areas has exposed them to adverse environmental conditions, as these groups often settle in marginal urban belts where basic services are lacking. This circumstance contributes to maintaining and even exacerbating ethnic gaps (Del Popolo and Oyarce, 2005).

In view of the above, the Millennium Development Goal referring to drinking water and sanitation is multidimensional, and as such is organically related to the previous ones, in particular those aiming for the improvement of social and economic living conditions, education and health. As recently suggested, the concept of access to basic services should go beyond the issue of coverage and consider their multiple effects on the population (United Nations, 2005).

As can be seen from figure 7, access to drinking water is more extensive in urban areas. There are a few exceptions, such as in Guatemala and Paraguay, countries in which drinking water coverage is slightly higher in rural areas (in general, the defining criteria used in the countryside are less demanding).

Figure 7

PERCENTAGE OF POPULATION WITH AN ADEQUATE SUPPLY OF WATER, BY INDIGENOUS AND NON-INDIGENOUS PEOPLE AND AREA OF RESIDENCE, 2000 CENSUSES

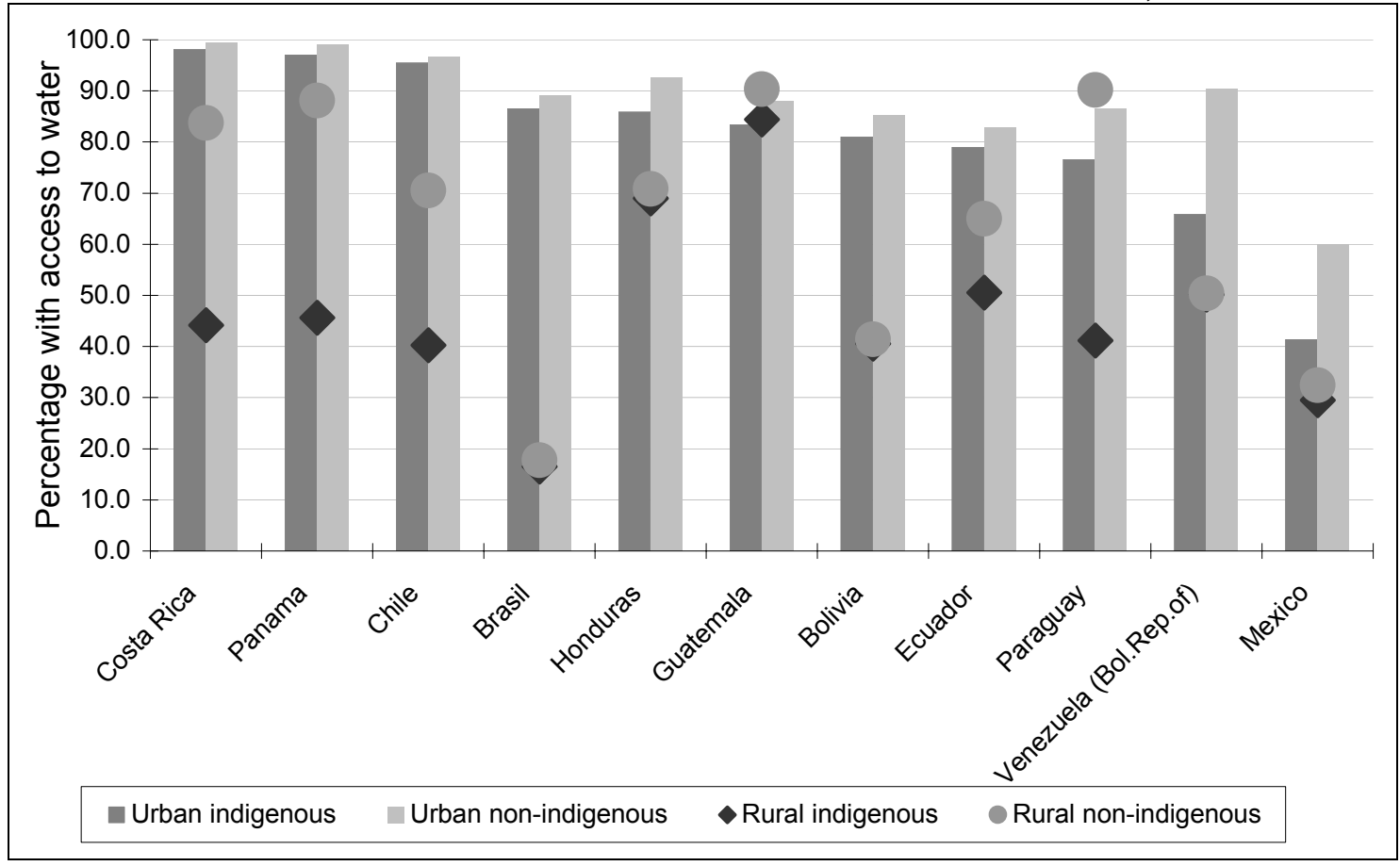

Source: annex table 5

Nevertheless, in both urban and rural areas, access to drinking water is higher among the nonindigenous population. In urban areas, the largest gaps are observed in countries which have low drinking water coverage, including Bolivarian Republic of Venezuela, Mexico and Paraguay. In rural areas, the ethnic differential is maintained and is sometimes larger. Paradoxically, this

54 In this connection, the message of indigenous peoples has been highlighted on a number of occasions, as in the case of their participation in the Earth Summit in 1992 and in the indigenous declarations at the World Water Forums. 
situation occurs in countries which have a reasonable provision of drinking water in urban areas, as in the case of indigenous and non-indigenous people in Chile, Costa Rica and Panama. In these countries, the ethnic inequity of access to water is mainly a rural problem.

At the same time, in countries where rural areas have scarce drinking water provision (Bolivarian Republic of Venezuela, Bolivia, Brazil, Mexico and Honduras), the situation is different, with a slight or almost non-existent ethnic gap. ${ }^{55}$

As shown above, the consequences of ethnic differences in terms of drinking water access are most serious in rural areas, which in several countries is where the main indigenous settlements are situated (United Nations, 2005; ECLAC, 2006a). Nevertheless, it is very clear that the differences in drinking water access in urban areas are larger in those countries that have a high percentage of indigenous population in the cities. This is the case of the Bolivarian Republic of Venezuela, Bolivia and Brazil, where over 50\% of the indigenous population is in urban areas (Del Popolo and Oyarce, 2005; ECLAC, 2006a). This does not apply in the case of Chile, which has the largest urban indigenous concentration (64.8\%) and only a small ethnic gap in drinking water access in those areas.

In general terms, in cities with larger indigenous populations, there is more access to drinking water (table 3). Among the indigenous populations, the level of provision of drinking water for indigenous population in La Paz, San Pedro Sula, Santiago (Chile), Sao Paulo and Mexico City is higher than the urban indigenous average. To a lesser extent, this situation also occurs among the indigenous persons of San José and Maracaibo. The exceptions are Guatemala City, Panama City, Quito and Fernheim, where the percentage of indigenous population with access to drinking water is lower than the overall urban rate. As for the indigenous residents of urban areas of Panama, the scarce provision of drinking water seems to be related to the marginal suburban or urban location of their homes (IDB/ECLAC, 2005c).

Although this assumes that living conditions are better for the indigenous people who live in these cities, the progress is not equitable, as there are still ethnic gaps in access to drinking water. In some jurisdictions, such as Guatemala City, Maracaibo, Mexico City and Quito, the relative differences in water supply of indigenous and non-indigenous population are actually increasing, to the detriment of indigenous peoples.

55 In Honduras, for example, indigenous peoples have voiced strong claims for the right to improve their living conditions in rural areas. The Indigenous Pilgrimages to the country's capital, which began in 1994, led to a process of peaceful negotiation which achieved a number of outcomes, including the creation of a Department of Ethnic Services in the Ministry of Health. In this context, one of the most significant government commitments is to improve drinking water supplies and ensure effective sanitation services for indigenous peoples (PAHO/WHO, 2001). 
Table 3

PERCENTAGE AND GAPS BETWEEN POPULATION GROUPS IN TERMS OF ADEQUATE PROVISION OF WATER IN THE MAIN URBAN CENTRES WITH INDIGENOUS POPULATION, BY ETHNIC CONDITION, 2000 CENSUSES

\begin{tabular}{l|c|c|c|c}
\hline \multirow{2}{*}{\multicolumn{1}{c|}{ City }} & \multicolumn{3}{|c}{ Access to Drinking Water } \\
\cline { 2 - 5 } & \multirow{2}{*}{ Indigenous } & Non-indigenous & \multicolumn{2}{c}{ Relative gap (*) } \\
\cline { 3 - 5 } & & & $\begin{array}{c}\text { Average urban } \\
\text { indigenous }\end{array}$ & $\begin{array}{c}\text { City non- } \\
\text { indigenous }\end{array}$ \\
\hline La Paz & 86.3 & 91.8 & 6.2 & -6.4 \\
Sao Paulo & 95.8 & 97.4 & 9.7 & -1.7 \\
Santiago & 98.3 & 99.0 & 2.9 & -0.7 \\
San José & 98.7 & 99.6 & 0.6 & -0.9 \\
Quito & 78.3 & 92.8 & -0.8 & -18.5 \\
Guatemala & 77.8 & 88.8 & -7.3 & -14.1 \\
San Pedro Sula & 95.0 & 95.9 & 9.6 & -1.0 \\
Mexico City & 53.1 & 63.1 & 22.1 & -19.0 \\
Panama City & 96.7 & 98.8 & -0.4 & -2.2 \\
Maracaibo & 67.0 & 87.4 & 1.6 & -30.6 \\
\hline
\end{tabular}

Source: Latin American and Caribbean Demographic Centre (CELADE) - Population Division of ECLAC, special processing of census microdata.

$\left({ }^{*}\right)$ This is calculated as: (percentage of indigenous access in the city-comparison percentage)/(percentage of indigenous access in the city*100). The gaps for La Paz, for example, read as follows: the access to drinking water of indigenous people living in La Paz is $6.2 \%$ higher than the urban indigenous average, and, in turn $6.4 \%$ less than the access of non-indigenous people in that city.

Figure 8

PERCENTAGE OF POPULATION WITH EFFICIENT SANITATION SERVICES, BY ETHNIC CONDITION AND AREA OF RESIDENCE, 2000 CENSUSES

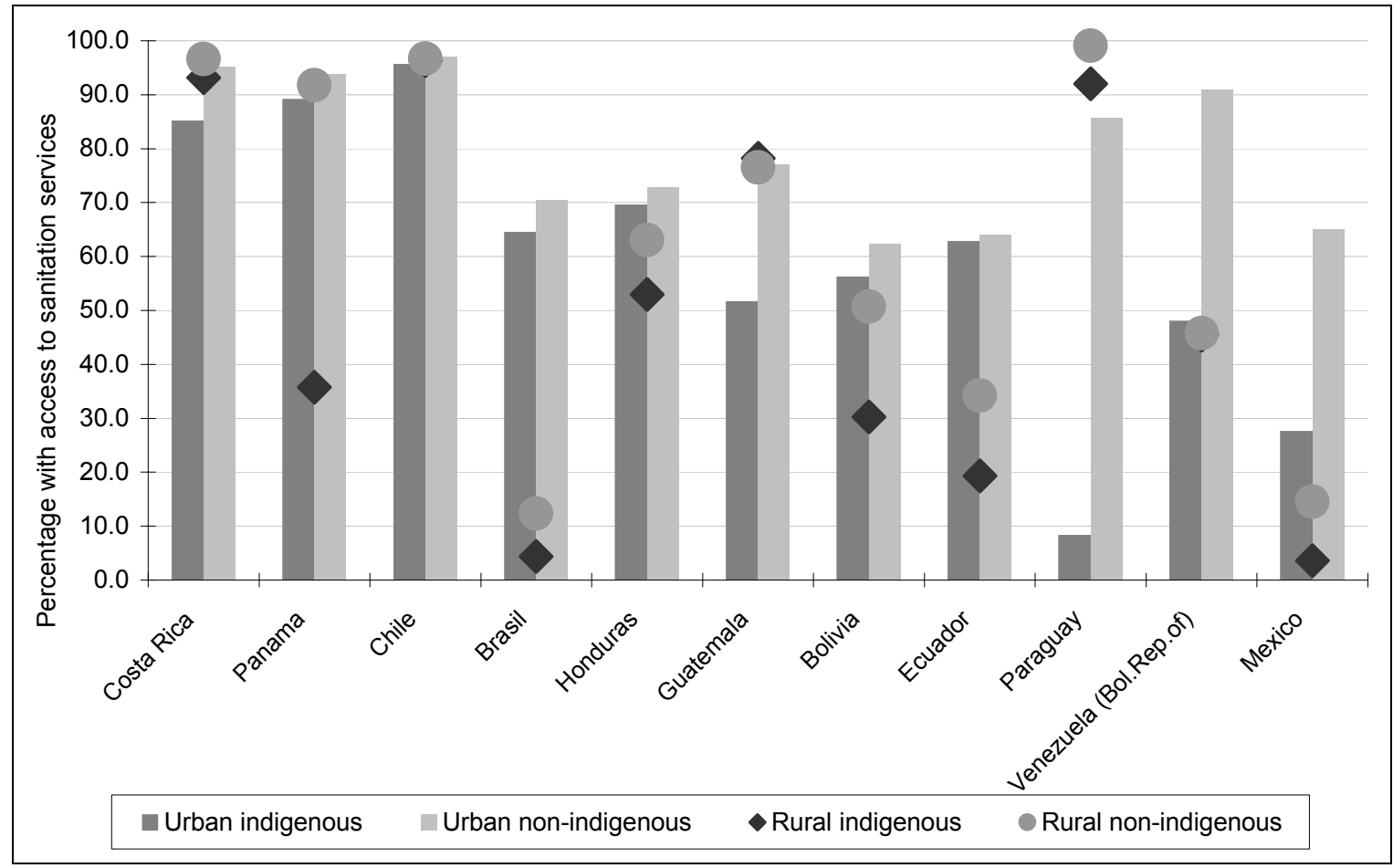

Source: annex table 5 
In general terms, and regardless of ethnic group or area of residence, the percentages of population with efficient sanitation services are lower than those reported for drinking water (figure 8). ${ }^{56}$

It is also clear that the percentage of the population with efficient sanitation tends to be higher in urban areas and, within those areas, among non-indigenous people. In that connection, the ethnic gaps for efficient sanitation in urban areas are much greater than in rural areas, especially in countries such as the Bolivarian Republic of Venezuela, Guatemala, Mexico and Paraguay.

In the cities with large indigenous populations, the percentage of the population with efficient sanitation is generally higher than the urban average for the ethnic groups considered (see table 4). The exceptions are Fernheim (Paraguay) and, to a lesser extent, Maracaibo, Panama City and San José. In all cities, the level of efficient sanitation services is higher among the non-indigenous inhabitants, except in San Pedro Sula. In this connection, the largest ethnic gaps are observed in Mexico City, Fernheim, Maracaibo and La Paz.

Table 4

PERCENTAGES AND GAPS BETWEEN POPULATION GROUPS IN TERMS OF ADEQUATE SANITATION SERVICES IN THE MAIN URBAN CENTRES WITH INDIGENOUS POPULATION, BY ETHNIC CONDITION, 2000 CENSUSES

\begin{tabular}{l|c|c|r|r}
\hline \multirow{2}{*}{\multicolumn{1}{c|}{ City }} & \multicolumn{2}{|c}{ Access to Efficient Sanitation } \\
\cline { 2 - 4 } & \multirow{2}{*}{ Indigenous } & Non-indigenous & \multicolumn{2}{|c}{ Relative gap (*) } \\
\cline { 3 - 5 } & & & $\begin{array}{c}\text { Average urban } \\
\text { indigenous }\end{array}$ & City non-indigenous \\
\hline La Paz & 62,1 & 81,3 & 9,5 & $-31,0$ \\
Sao Paulo & 82,0 & 87,8 & 21,3 & $-7,0$ \\
Santiago & 98,5 & 99,3 & 3,0 & $-0,7$ \\
San José & 81,3 & 95,5 & $-4,6$ & $-17,5$ \\
Quito & 77,3 & 90,9 & 18,7 & $-17,5$ \\
Guatemala & 82,4 & 85,7 & 37,3 & $-4,0$ \\
San Pedro Sula & 92,7 & 89,1 & 24,9 & 3,8 \\
Mexico City & 44,1 & 67,9 & 37,6 & $-53,9$ \\
Panama City & 87,2 & 93,5 & $-2,3$ & $-7,3$ \\
Fernheim & 0,9 & 77,8 & $-826,5$ & $-8589,5$ \\
Maracaibo & 44,7 & 92,0 & $-7,4$ & $-105,6$ \\
\hline
\end{tabular}

Source: Latin American and Caribbean Demographic Centre (CELADE) - Population Division of ECLAC, special processing of census microdata.

$\left(^{*}\right)$ This is calculated as: (percentage of indigenous access in the city-comparison percentage)/(percentage of indigenous access in the city*100). The gaps for La Paz, for example, read as follows: the access to efficient sanitation services of indigenous people living in La Paz is $9.5 \%$ higher than the urban indigenous average, and, in turn $31 \%$ less than the access of non-indigenous people in that city.

\section{Final reflections}

On the basis of the conventional indicators on education, health and access to basic services, the living conditions of urban indigenous populations are more favourable than those of indigenous people in rural areas. Nevertheless, ethnic inequities persist in the cities and in some cases are intensified, reflecting the discrimination and social exclusion that affect indigenous persons who live in cities.

56 With the exception of Chile, where the situation is entirely different, some countries have their higher levels of sanitation services mainly in rural areas. This circumstance may be due to the difficulty of finding exact equivalents between the unmet basic needs indicators and the census categories that describe the efficiency of rural sanitation services compared with those of urban areas. 
As for education, and taking into account the targets associated with the Millennium Development Goals, it can be said that access to primary education in urban areas in Latin America is very close to being universal, although in some countries there are significant gaps to the disadvantage of indigenous children. The data also show that the target for completion of the primary cycle will be much more difficult to reach in the case of the indigenous peoples, even in urban areas. Moreover, as they move up through the educational levels, the opportunities for access for young indigenous people diminish, and the gender gap becomes more obvious.

Access to education, and thus to information, has an impact on the decision-making and autonomy of indigenous peoples. Nevertheless, there is still the challenge of designing education policies that respond to the sociocultural and linguistic conditions of different indigenous peoples, in urban as well as rural areas. The high proportion of young indigenous people who do not speak their native language reflects the structural cultural loss that takes place as a result of displacement, disaggregation and atomization of indigenous languages. On the other hand, with a view to encouraging a process of "integration" into the global Spanish-speaking society and avoiding discrimination, indigenous parents themselves choose not to teach their native language to their children. For this reason, if educational policies do not promote education with a multicultural focus in all social groups, it will be difficult to reverse this process.

As for the early childhood mortality of indigenous boys and girls, the risks are lower in urban areas than in rural areas, but the probability of dying before reaching the age of five is consistently higher than for urban non-indigenous children. This fact reflects the integration of indigenous groups into the poorest socioeconomic strata in urban areas, where the conditions of social exclusion and discrimination are accentuated (León, 2003).

As relatively greater efforts are needed to ensure that the indigenous peoples achieve Goal 4 and target 5 deriving from the Millennium Declaration, mother and child health programmes should take into account the diversity of indigenous peoples, areas and local contexts by designing policies on a territorial basis, while cultural accessibility should be ensured not only in rural areas.

Access to basic services -water and sanitation- is in line with the general trends described for education and health: although access is improving in urban areas, there are still ethnic gaps in the cities and in some countries they are increasing.

This brief overview was made possible by the inclusion of a question on ethnic identity in the censuses. Despite the associated limitations, the review of the living conditions of urban indigenous population can be extended to cover different territorial contexts, ethnic group and origin of residents (former migrants, recent migrants, non-migrants, etc.), in order to produce relevant knowledge as an input to improve the design and implementation of public policies.

\section{Bibliography}

Busso, M., M. Cicowiez and L. Gasparini (2005), Etnicidad y los objetivos del milenio en América Latina y el Caribe, Buenos Aires, Inter-American Development Bank (IDB)/Economic Commission for Latin America and the Caribbean (ECLAC)/United Nations Development Programme (UNDP).

Calvo, María del Rosario (2005), "Efectos de la migración Ngöbe Buglé en el servicio de pediatría del Hospital Dr. Maximiliano Peralta de Cartago", Acta médica costarricense, vol. 47, N² 2, San José, April.

Cicowiez, Martín and others (2006), "Áreas rurales y objetivos de desarrollo del Milenio en América Latina y El Caribe", documento de trabajo $\mathrm{N}^{\circ} 43$, Buenos Aires, Centro de Estudios Distributivos Laborales y Sociales (CEDLAS), Universidad Nacional de La Plata.

Del Popolo, Fabiana and Ana María Oyarce (2005), "América Latina, población indígena: perfil sociodemográfico en el marco de la Conferencia Internacional sobre la Población y el Desarrollo y de las metas del Milenio", Notas de población No 79 (LC/G.2284-P), Santiago, Chile, Economic Commission for Latin America and the Caribbean (ECLAC), June. United Nations publication, Sales $\mathrm{N}^{\circ}$ S.05.II.G.141. 
Deruyttere, Anne (1997), "Indigenous peoples and sustainable development: the role of the Inter-American Development Bank", IDB Forum of the Americas No IND97-101, Washington, D.C.

ECLAC (Economic Commission for Latin America and the Caribbean) (2006a), Social Panorama of Latin America 2006 (LC/G.2326-P), Santiago, Chile, December.

(2006b), "Pueblos indígenas y afrodescendientes de América Latina: información sociodemográfica para políticas y programas", Project documents $\mathrm{N}^{\circ} 72$ (LC/W.72), Santiago, Chile, May.

(2006c), Social Panorama of Latin America 2005 (LC/G.2288-P), Santiago, Chile, March. United Nations publication, Sales No E.05.II.G.161.

(2000), Equity, Development and Citizenship (LC/G.2071/Rev.1-P), Santiago, Chile. United Nations publication, Sales No E.00.II.G.81.

ECLAC/CELADE/CIDOB/UNFPA/ICI (Economic Commission for Latin America and the Caribbean/Latin American Demographic Centre/Confederation of Indigenous People of Bolivia/United Nations Population Fund/Ibero-American Cooperation Institute) (1994), "Estudio sociodemográfico de los pueblos indígenas", series $E \mathrm{~N}^{\circ} 40$ (LC/DEM/G.146), Santiago, Chile.

ECLAC (Economic Commission for Latin America and the Caribbean)/Fund for the Development of the Indigenous Peoples of Latin America and the Caribbean) (2007), Project "System of Sociodemographic Indicators for Indigenous Peoples and Populations (SISPPI)" (FIA/06/001), Santiago, Chile.

IDB/ECLAC (Inter-American Development Bank/Economic Commission for Latin America and the Caribbean) (2005a), "Los pueblos indígenas de Bolivia: diagnóstico sociodemográfico a partir del censo del 2001", Project documents $\mathrm{N}^{\circ} 24$ (LC/W.24), Santiago, Chile.

(2005b), "Población indígena y afroecuatoriana en Ecuador: diagnóstico sociodemográfico a partir del censo de 2001", Project documents $\mathrm{N}^{\circ} 16$ (LC/W.16), Santiago, Chile.

(2005c), "Los pueblos indígenas de Panamá: diagnóstico sociodemográfico a partir del censo del 2000", Project documents $\mathrm{N}^{\circ} 20$ (LC/W.20), Santiago, Chile.

(2005d), Atlas sociodemográfico de los pueblos indígenas de Panamá (LC/R.2124), Santiago, Chile, April.

(2005e), Atlas sociodemográfico de los pueblos indígenas de Bolivia (LC/R.2126), Santiago, Chile, June.

(2005f), Atlas sociodemográfico de la población indígena y afro ecuatoriana de Ecuador (LC/R.2127), Santiago, Chile, August.

Enge, Kjell (1998), "Salud y reproducción: qué piensan, sienten y desean los mayas", Documento de trabajo $\mathrm{N}^{\mathrm{o}} 20$, Mexico City, Population Council.

Guerrero, Fernando (2005), "Población indígena y afroecuatoriana en el Ecuador, a partir de la información censal del 2001", Pueblos indígenas y afrodescendientes de América Latina y el Caribe: información sociodemográfica para políticas y programas, Project documents $\mathrm{N}^{\circ} 72$ (LC/W.72), Santiago, Chile, Economic Commission for Latin America and the Caribbean (ECLAC).

Kunitz, Stephen J. (1994), "Disease and the destruction of indigenous population", Humanity, Culture and Social Life: An Encyclopedia of Anthropoloy, London, Routledge.

León, Guadalupe (2003), "Ecuador. Etnicidad, pobreza y exclusión de los indígenas inmigrantes en Quito, Guayaquil y Tena", Exclusión social y estrategias de vida de los indígenas urbanos en Perú, México y Ecuador, Washington, D.C., World Bank.

Martínez, Jorge (2000), "La migración internacional y el desarrollo en la era de la globalización e integración: temas para una agenda regional", Población y desarrollo serie No 10 (LC/L.1459-P/E), Santiago, Chile, Economic Commission for Latin America and the Caribbean (ECLAC), December. United Nations publication, Sales $\mathrm{N}^{\circ}$ S.00.II.G.140.

Molnar, Augusta, Tania Carrasco and Kathryn Johns-Swartz (2003), "México: pueblos indígenas, identidad y pobreza en las ciudades de México, Cancún y Coatzacoalcos-Minatitlán", Exclusión social y estrategias de vida de los indígenas urbanos en Perú, México y Ecuador, Washington, D.C.,World Bank.

Montenegro, Raúl and Carolyn Stephens (2006), "Indigenous health in Latin America and the Caribbean", The Lancet, vol. 367, 3 June.

PAHO (Pan American Health Organization) (2006), Encuentro internacional de desarrollo infantil en el marco de los objetivos de desarrollo del Milenio (Belém do Pará, junio 2004) (OPS/FCH/06.03.E), Washington, D.C. (2004), "Healing our spirit worldwide", Newsletter for Indigenous People, Edition № 2, May.

PAHO/WHO (Pan American Health Organization/World Health Organization) (2001), Salud de los pueblos indigenas y negros de Honduras. Interculturalidad y procesos de convergencia nacional, Washington, D.C., Departamento de Atención a las Etnias, Secretaría de salud de Honduras (DAE)/Confederación 
Nacional de Pueblos Autóctonos de Honduras (CONPAH)/Swedish International Development Cooperation Agency (OSDI).

Peredo Beltrán, Elizabeth (2004), “Una aproximación a la problemática de género y etnicidad en América Latina", Mujer y desarrollo series N 53 (LC/L.2066-P), Santiago, Chile, Economic Commission for Latin America and the Caribbean (ECLAC), April. United Nations publication, Sales N ${ }^{\circ}$ S.04.II.G.9.

Quesnel, André (2006), "Dinámicas demo-sociales de la población indígena y afrodescendiente en América Latina", Pueblos indígenas y afrodescendientes de América Latina y el Caribe: información sociodemográfica para políticas y programas, Project documents No 72 (LC/W.72), Santiago, Chile, Economic Commission for Latin America and the Caribbean (ECLAC).

Rojas, Rocío (2006), "Condiciones de vida y salud de los pueblos indígenas de las América”, Pueblos indígenas y afrodescendientes de América Latina y el Caribe: información sociodemográfica para políticas y programas, Project documents $\mathrm{N}^{\mathrm{o}} 72$ (LC/W.72), Santiago, Chile, Economic Commission for Latin America and the Caribbean (ECLAC).

Schkolnik, Susana and Fabiana Del Popolo (2005), "Los censos y los pueblos indígenas en América Latina: una metodología regional", Notas de población $\mathrm{N}^{\circ} 79$ (LC/G.2284-P/E), Santiago, Chile, Economic Commission for Latin America and the Caribbean (ECLAC), July. United Nations publication, Sales $\mathrm{N}^{\circ}$ S.05.II.G.141.

Stephens, Carolyn and others (2006), "Disappearing, displaced, and undervalued: a call to action for indigenous health worldwide", The Lancet, vol. 367, 17 June.

UNESCO (United Nations Educational, Scientific and Cultural Organization) (2004), Universal Primary Completion in Latin America: Are We Really so Near the Goal?, Santiago, Chile, UNESCO Regional Office for Education in Latin America and the Caribbean.

United Nations (2005), The Millennium Development Goals: A Latin American and Caribbean Perspective (LC/G.2331-P), José Luis Machinea, Alicia Bárcena and Arturo León (coords.), Santiago, Chile, Economic Commission for Latin America and the Caribbean (ECLAC). United Nations publication, Sales No E.05.II.G.107.

(2000), United Nations Millennium Declaration. Resolution adopted by the General Assembly (A/RES/55/2), New York. (1983), Manual X. Indirect Techniques for Demographic Estimation (ST/ESA/SER.A/81), New York, United Nations publication, Sales N ${ }^{\mathrm{o}}$ E.83.XIII.2

UNPFII (United Nations Permanent Forum on Indigenous Issues) (2006), Report of the International Expert Group Meeting on the Millennium Development Goals, Indigenous Participation and Good Governance (E/C.19/2006/7), New York, March.

Vigo, M. M. and A. Chávez (2003), "Perú. Etnicidad, pobreza, exclusión social: la situación de los inmigrantes indígenas en las ciudades de Cuzco y Lima”, Exclusión social y estrategias de vida de los indígenas urbanos en Perú, México y Ecuador, Washington, D.C., World Bank. 


\section{Annex}


Annex 1

\begin{tabular}{|c|c|c|c|c|c|c|c|c|c|c|c|c|c|}
\hline \multirow{3}{*}{ Sex } & \multirow{3}{*}{ Country } & \multicolumn{4}{|c|}{$\begin{array}{l}\text { Attendance rate for population aged 6-11 } \\
\text { years }\end{array}$} & \multicolumn{4}{|c|}{$\begin{array}{l}\text { Percentage of } 15-19 \text { year olds who } \\
\text { complete primary education }\end{array}$} & \multicolumn{4}{|c|}{$\begin{array}{l}\text { Literacy rate for population aged 15- } \\
\qquad 24 \text { years }\end{array}$} \\
\hline & & \multicolumn{2}{|c|}{ Indigenous } & \multicolumn{2}{|c|}{ Non-indigenous } & \multicolumn{2}{|c|}{ Indigenous } & \multicolumn{2}{|c|}{ Non-indigenous } & \multicolumn{2}{|c|}{ Indigenous } & \multicolumn{2}{|c|}{$\begin{array}{c}\text { Non- } \\
\text { indigenous }\end{array}$} \\
\hline & & Urban & Rural & Urban & Rural & Urban & Rural & Urban & Rural & Urban & Rural & Urban & Rural \\
\hline \multirow{11}{*}{ Both sexes } & Bolivia & 95.8 & 89.9 & 95.2 & 87.4 & 85.6 & 59.4 & 90.3 & 60.5 & 98.4 & 93.5 & 99.1 & 95.2 \\
\hline & Brazil & 91.9 & 62.7 & 95.0 & 86.9 & 85.7 & 41.3 & 89.2 & 67.0 & 95.9 & 71.5 & 96.7 & 86.8 \\
\hline & Chile & III & III & III & III & 95.1 & 89.2 & 96.0 & 92.3 & 99.0 & 97.3 & 99.2 & 97.9 \\
\hline & Costa Rica & 93.9 & 71.0 & 97.2 & 93.0 & 79.5 & 49.6 & 90.2 & 78.8 & 97.1 & 81.5 & 98.8 & 96.4 \\
\hline & Ecuador & 89.7 & 85.8 & 93.1 & 87.2 & 75.2 & 67.9 & 86.4 & 76.2 & 94.9 & 92.2 & 97.5 & 95.1 \\
\hline & Guatemala & 87.2 & 78.6 & 94.1 & 84.4 & 52.4 & 28.8 & 79.2 & 47.7 & 82.0 & 66.1 & 95.1 & 82.0 \\
\hline & Honduras & 89.3 & 72.4 & 87.3 & 72.8 & 78.5 & 42.8 & 79.6 & 50.8 & 95.6 & 80.2 & 95.7 & 82.5 \\
\hline & Mexico & 91.2 & 90.3 & 96.9 & 94.3 & 76.1 & 64.4 & 92.9 & 80.3 & 90.9 & 82.9 & 98.3 & 93.8 \\
\hline & Panama & 88.2 & 76.9 & 97.8 & 95.7 & 79.1 & 49.5 & 96.0 & 87.7 & 93.3 & 72.1 & 99.2 & 96.5 \\
\hline & Paraguay & 71.1 & 59.2 & 94.8 & 91.8 & 33.5 & 21.3 & 87.9 & 76.1 & 83.6 & 62.1 & 98.0 & 97.0 \\
\hline & Venezuela (Bol.Rep.of) & 76.7 & 68.0 & 96.0 & 87.8 & 59.7 & 44.3 & 89.0 & 65.2 & 84.9 & 68.6 & 98.3 & 90.9 \\
\hline \multirow{11}{*}{ Men } & Bolivia & 95.8 & 90.5 & 95.0 & 86.9 & 90.4 & 67.5 & 91.3 & 62.7 & 99.4 & 96.9 & 99.3 & 96.4 \\
\hline & Brazil & 91.5 & 62.3 & 94.7 & 86.2 & 84.0 & 43.1 & 87.2 & 61.8 & 95.1 & 74.6 & 95.9 & 83.8 \\
\hline & Chile & III & III & III & III & 94.5 & 88.6 & 95.5 & 91.7 & 98.9 & 97.2 & 99.0 & 97.5 \\
\hline & Costa Rica & 94.3 & 71.3 & 97.0 & 92.7 & 78.6 & 50.5 & 89.3 & 77.0 & 97.1 & 83.2 & 98.5 & 95.7 \\
\hline & Ecuador & 90.0 & 86.2 & 92.8 & 86.8 & 77.3 & 72.2 & 85.8 & 75.3 & 95.8 & 94.7 & 97.4 & 94.8 \\
\hline & Guatemala & 88.2 & 80.1 & 94.1 & 84.6 & 58.7 & 35.6 & 80.5 & 50.5 & 87.6 & 75.9 & 95.9 & 84.0 \\
\hline & Honduras & 88.5 & 71.9 & 86.7 & 71.6 & 76.3 & 40.6 & 77.5 & 47.0 & 95.4 & 78.7 & 95.0 & 79.9 \\
\hline & Mexico & 91.7 & 90.6 & 96.8 & 94.2 & 78.6 & 68.9 & 92.7 & 79.9 & 92.9 & 87.8 & 98.3 & 93.7 \\
\hline & Panama & 87.6 & 77.7 & 97.7 & 95.3 & 82.3 & 55.5 & 95.4 & 85.5 & 95.0 & 79.8 & 99.2 & 96.0 \\
\hline & Paraguay & 69.0 & 59.1 & 94.4 & 91.3 & 33.4 & 25.6 & 87.2 & 75.7 & 85.8 & 66.3 & 97.9 & 97.3 \\
\hline & Venezuela (Bol.Rep.of) & 75.4 & 67.7 & 95.8 & 86.8 & 56.2 & 44.8 & 86.7 & 59.1 & 84.1 & 70.7 & 97.8 & 88.4 \\
\hline \multirow{11}{*}{ Women } & Bolivia & 95.8 & 89.2 & 95.4 & 87.9 & 81.5 & 50.9 & 89.4 & 57.9 & 97.5 & 90.0 & 98.9 & 93.7 \\
\hline & Brazil & 92.4 & 63.1 & 95.4 & 87.6 & 87.3 & 39.4 & 91.3 & 72.9 & 96.6 & 68.0 & 97.6 & 90.4 \\
\hline & Chile & III & III & III & III & 95.7 & 89.9 & 96.4 & 93.0 & 99.2 & 97.5 & 99.3 & 98.4 \\
\hline & Costa Rica & 93.4 & 70.6 & 97.3 & 93.3 & 80.3 & 48.5 & 91.2 & 80.8 & 97.1 & 79.6 & 99.0 & 97.2 \\
\hline & Ecuador & 89.3 & 85.3 & 93.4 & 87.5 & 73.2 & 64.0 & 86.9 & 77.2 & 94.0 & 90.0 & 97.6 & 95.5 \\
\hline & Guatemala & 86.3 & 77.1 & 94.2 & 84.2 & 46.7 & 22.3 & 77.9 & 45.0 & 76.8 & 57.2 & 94.3 & 80.1 \\
\hline & Honduras & 90.2 & 73.0 & 87.8 & 74.1 & 80.4 & 45.2 & 81.4 & 55.1 & 95.8 & 81.8 & 96.3 & 85.3 \\
\hline & Mexico & 90.7 & 90.0 & 97.1 & 94.4 & 73.7 & 59.7 & 93.1 & 80.6 & 89.0 & 78.1 & 98.4 & 93.8 \\
\hline & Panama & 88.8 & 76.0 & 97.9 & 96.0 & 75.9 & 43.1 & 96.6 & 90.2 & 91.5 & 64.4 & 99.3 & 97.1 \\
\hline & Paraguay & 73.1 & 59.2 & 95.2 & 92.3 & 33.6 & 16.9 & 88.6 & 76.5 & 81.8 & 57.7 & 98.0 & 96.7 \\
\hline & Venezuela (Bol.Rep.of) & 78.1 & 68.3 & 96.3 & 88.7 & 62.9 & 43.7 & 91.3 & 72.9 & 85.6 & 66.2 & 98.8 & 94.0 \\
\hline
\end{tabular}


Table 2

\begin{tabular}{|c|c|c|c|c|c|c|c|}
\hline \multirow{2}{*}{ Sex } & \multirow{2}{*}{ City } & \multicolumn{2}{|c|}{$\begin{array}{c}\text { Attendance rate for } \\
\text { population aged } 6-11 \\
\text { years }\end{array}$} & \multicolumn{2}{|c|}{$\begin{array}{l}\text { Percentage of } 15-19 \text { year } \\
\text { olds who complete } \\
\text { primary education }\end{array}$} & \multicolumn{2}{|c|}{$\begin{array}{c}\text { Literacy rate for } \\
\text { population aged } 15-24 \\
\text { years }\end{array}$} \\
\hline & & Indigenous & $\begin{array}{c}\text { Non- } \\
\text { indigenous }\end{array}$ & Indigenous & $\begin{array}{c}\text { Non- } \\
\text { indigenous }\end{array}$ & Indigenous & $\begin{array}{c}\text { Non- } \\
\text { indigenous }\end{array}$ \\
\hline \multirow{11}{*}{$\begin{array}{l}\text { Both } \\
\text { sexes }\end{array}$} & La Paz & 96.5 & 96.9 & 89.0 & 94.1 & 99.0 & 99.4 \\
\hline & Sao Paulo & 93.3 & 95.0 & 92.8 & 94.4 & 96.9 & 98.7 \\
\hline & Santiago & III & III & 94.4 & 96.1 & 99.1 & 99.3 \\
\hline & San José & 90.9 & 97.0 & 78.7 & 91.0 & 97.6 & 99.0 \\
\hline & Quito & 89.3 & 95.3 & 73.9 & 90.3 & 94.2 & 98.4 \\
\hline & Guatemala City & 89.8 & 96.0 & 56.8 & 84.3 & 87.0 & 96.9 \\
\hline & San Pedro Sula & 85.6 & 85.5 & 81.3 & 79.4 & 97.0 & 96.4 \\
\hline & Mexico City & 91.6 & 98.1 & 81.7 & 95.9 & 94.4 & 99.1 \\
\hline & Panama City & 89.4 & 97.7 & 82.5 & 96.1 & 96.4 & 99.3 \\
\hline & Fernheim & 74.4 & 93.8 & 36.1 & 94.2 & 86.4 & 99.2 \\
\hline & Maracaibo & 73.7 & 94.1 & 55.7 & 87.6 & 83.1 & 97.7 \\
\hline \multirow{11}{*}{ Men } & La Paz & 96.6 & 96.9 & 93.4 & 95.2 & 99.7 & 99.6 \\
\hline & Sao Paulo & 91.4 & 94.8 & 90.8 & 93.9 & 95.7 & 98.4 \\
\hline & Santiago & III & III & 93.9 & 95.7 & 99.0 & 99.1 \\
\hline & San José & 91.9 & 96.8 & 79.1 & 90.4 & 97.6 & 98.8 \\
\hline & Quito & 90.4 & 95.3 & 77.0 & 90.5 & 95.7 & 98.4 \\
\hline & Guatemala City & 90.3 & 95.9 & 65.9 & 85.8 & 92.9 & 97.5 \\
\hline & San Pedro Sula & 84.9 & 84.8 & 83.8 & 78.8 & 97.3 & 96.1 \\
\hline & Mexico City & 92.4 & 98.1 & 83.3 & 96.0 & 95.8 & 99.2 \\
\hline & Panama City & 88.4 & 97.6 & 87.0 & 95.5 & 98.1 & 99.3 \\
\hline & Fernheim & 71.4 & 93.1 & 34.0 & 94.1 & 88.0 & 98.8 \\
\hline & Maracaibo & 72.5 & 93.6 & 51.8 & 85.2 & 82.3 & 97.0 \\
\hline \multirow{11}{*}{ Women } & La Paz & 96.4 & 96.9 & 85.3 & 93.0 & 98.5 & 99.2 \\
\hline & Sao Paulo & 95.3 & 95.2 & 94.5 & 94.9 & 97.9 & 98.9 \\
\hline & Santiago & III & III & 94.9 & 96.4 & 99.2 & 99.4 \\
\hline & San José & 89.9 & 97.1 & 78.3 & 91.7 & 97.6 & 99.2 \\
\hline & Quito & 88.2 & 95.3 & 71.3 & 90.0 & 92.8 & 98.3 \\
\hline & Guatemala City & 89.3 & 96.1 & 49.9 & 82.9 & 82.2 & 96.3 \\
\hline & San Pedro Sula & 86.4 & 86.2 & 79.5 & 79.9 & 96.8 & 96.6 \\
\hline & Mexico City & 90.7 & 98.1 & 80.7 & 95.9 & 93.5 & 99.0 \\
\hline & Panama City & 90.3 & 97.8 & 78.0 & 96.6 & 94.7 & 99.4 \\
\hline & Fernheim & 77.3 & 94.7 & 38.0 & 94.3 & 85.1 & 99.6 \\
\hline & Maracaibo & 75.0 & 94.6 & 59.3 & 90.0 & 83.8 & 98.4 \\
\hline
\end{tabular}


Table 3

RATIO OF SCHOOL ATTENDANCE RATES FOR PRIMARY, SECONDARY AND HIGHER EDUCATION BY ETHNIC STATUS AND AREA OF RESIDENCE, 2000 CENSUSES

\begin{tabular}{|c|c|c|c|c|c|c|c|c|c|c|c|c|}
\hline \multirow{3}{*}{ Country } & \multicolumn{4}{|c|}{ Primary ratio } & \multicolumn{4}{|c|}{ Secondary ratio } & \multicolumn{4}{|c|}{ Higher ratio } \\
\hline & \multicolumn{2}{|c|}{ Indigenous } & \multicolumn{2}{|c|}{ Non-indigenous } & \multicolumn{2}{|c|}{ Indigenous } & \multicolumn{2}{|c|}{ Non-indigenous } & \multicolumn{2}{|c|}{ Indigenous } & \multicolumn{2}{|c|}{ Non-indigenous } \\
\hline & Urban & Rural & Urban & Rural & Urban & Rural & Urban & Rural & Urban & Rural & Urban & Rural \\
\hline Bolivia & 1.00 & 0.99 & 1.00 & 1.01 & 0.98 & 0.76 & 1.02 & 0.92 & 0.90 & 0.91 & 0.98 & 1.15 \\
\hline Brazil & 1.01 & 1.01 & 1.01 & 1.02 & 1.10 & 1.00 & 1.07 & 1.19 & 1.10 & 0.47 & 1.26 & 1.97 \\
\hline Costa Rica & 0.99 & 0.99 & 1.00 & 1.01 & 1.05 & 1.02 & 1.07 & 1.14 & 1.13 & 1.03 & 1.12 & 1.23 \\
\hline Ecuador & 0.99 & 0.99 & 1.01 & 1.01 & 0.93 & 0.79 & 1.03 & 1.07 & 0.78 & 0.49 & 1.06 & 1.15 \\
\hline Guatemala & 0.98 & 0.96 & 1.00 & 1.00 & 0.81 & 0.66 & 0.96 & 0.91 & 0.64 & 0.43 & 0.91 & 0.87 \\
\hline Honduras & 1.02 & 1.01 & 1.01 & 1.04 & 1.14 & 1.26 & 1.11 & 1.34 & 1.26 & 1.26 & 1.11 & 1.40 \\
\hline Mexico & 0.99 & 0.99 & 1.00 & 1.00 & 0.90 & 0.86 & 1.02 & 0.98 & 0.71 & 0.63 & 0.90 & 0.84 \\
\hline Panama & 1.01 & 0.98 & 1.00 & 1.01 & 0.86 & 0.74 & 1.02 & 1.18 & 0.93 & 0.50 & 1.43 & 1.94 \\
\hline Paraguay & 1.06 & 1.00 & 1.01 & 1.01 & 1.09 & 0.74 & 1.03 & 1.02 & 0.42 & 0.35 & 1.11 & 1.45 \\
\hline Venezuela (Bol.Rep.of) & 1.04 & 1.01 & 1.01 & 1.02 & 1.17 & 1.04 & 1.08 & 1.36 & 1.83 & 1.75 & 1.53 & 2.96 \\
\hline
\end{tabular}

Source: Latin American and Caribbean Demographic Centre (CELADE) - Population Division of ECLAC on the basis of special processing of census microdata.

Table 4

RATIO OF SCHOOL ATTENDANCE RATES FOR PRIMARY, SECONDARY AND HIGHER EDUCATION IN THE PRINCIPAL URBAN AGGLOMERATIONS WITH A CONCENTRATION OF ETHNIC GROUPS, 2000 CENSUSES

\begin{tabular}{|c|c|c|c|c|c|c|}
\hline \multirow{2}{*}{ Country } & \multicolumn{2}{|c|}{ Primary ratio } & \multicolumn{2}{|c|}{ Secondary ratio } & \multicolumn{2}{|c|}{ Higher ratio } \\
\hline & Indigenous & Non-indigenous & Indigenous & Non-indigenous & Indigenous & Non-indigenous \\
\hline La Paz & 1.00 & 1.00 & 0.97 & 1.01 & 0.88 & 0.96 \\
\hline Sao Paulo & 1.04 & 1.00 & 1.06 & 1.02 & 1.66 & 1.11 \\
\hline San José & 0.98 & 1.00 & 1.02 & 1.05 & 1.03 & 1.10 \\
\hline Quito & 0.98 & 1.00 & 0.82 & 0.97 & 0.65 & 0.93 \\
\hline Guatemala & 0.99 & 1.00 & 0.75 & 0.96 & 0.62 & 0.90 \\
\hline San Pedro Sula & 1.02 & 1.02 & 0.99 & 1.03 & 0.94 & 0.98 \\
\hline Mexico City & 0.98 & 1.00 & 0.64 & 1.02 & 0.49 & 0.89 \\
\hline Panama City & 1.02 & 1.00 & 0.85 & 1.01 & 0.84 & 1.36 \\
\hline Fernheim & 1.08 & 1.02 & 1.64 & 1.07 & 0.43 & 2.33 \\
\hline Maracaibo & 1.04 & 1.01 & 1.19 & 1.08 & 1.85 & 1.35 \\
\hline
\end{tabular}

Source: Latin American and Caribbean Demographic Centre (CELADE) - Population Division of ECLAC on the basis of special processing of census microdata.

Technical note: the secondary education rates used for the sex ratio are calculated taking into account the net rate for ISCED levels 2 and 3 (lower and upper secondary) and for higher education, it is a gross attendance rate at the tertiary or university level (in the latter case, this includes postgraduates). To calculate the net secondary education rate, the official ages that are valid at the time of the census in each of the countries are used, both in the numerator and the denominator. As for the gross higher education rate, the numerator includes all those attending, regardless of age and the denominator includes the population belonging to the five-year age group that follows completion of secondary school. 
Table 5 PERCENTAGE OF POPULATION WITH ACCESS TO SAFE DRINKING WATER AND EFFICIENT SANITATION SERVICES, BY ETHNIC STATUS AND AREA OF RESIDENCE, 2000 CENSUSES

\begin{tabular}{|c|c|c|c|c|c|c|c|c|}
\hline \multirow{3}{*}{ Country } & \multicolumn{4}{|c|}{ Drinking water } & \multicolumn{4}{|c|}{ Sanitation services } \\
\hline & \multicolumn{2}{|c|}{ Indigenous } & \multicolumn{2}{|c|}{ Non-indigenous } & \multicolumn{2}{|c|}{ Indigenous } & \multicolumn{2}{|c|}{ Non-indigenous } \\
\hline & Urban & Rural & Urban & Rural & Urban & Rural & Urban & Rural \\
\hline Bolivia & 80.9 & 40.5 & 85.3 & 41.4 & 56.2 & 30.3 & 62.4 & 50.7 \\
\hline Brazil & 86.5 & 16.5 & 89.2 & 17.7 & 64.5 & 4.4 & 70.5 & 12.3 \\
\hline Chile & 95.5 & 40.2 & 96.8 & 70.5 & 95.6 & 96.3 & 97.1 & 96.7 \\
\hline Costa Rica & 98.1 & 44.2 & 99.4 & 83.7 & 85.1 & 93.1 & 95.1 & 96.6 \\
\hline Ecuador & 78.9 & 50.5 & 83.0 & 65.0 & 62.8 & 19.3 & 64.0 & 34.2 \\
\hline Guatemala & 83.4 & 84.4 & 88.0 & 90.4 & 51.7 & 78.2 & 77.1 & 76.6 \\
\hline Honduras & 85.9 & 69.0 & 92.6 & 70.8 & 69.6 & 53.0 & 72.9 & 63.1 \\
\hline Mexico & 41.3 & 29.5 & 60.1 & 32.4 & 27.5 & 3.6 & 65.1 & 14.5 \\
\hline Panama & 97.1 & 45.6 & 99.1 & 88.1 & 89.1 & 35.8 & 93.9 & 91.7 \\
\hline Paraguay & 76.6 & 41.1 & 86.5 & 90.1 & 8.3 & 92.0 & 85.8 & 99.1 \\
\hline Venezuela (Bol.Rep.of) & 65.9 & 50.2 & 90.4 & 50.4 & 48.0 & 45.4 & 91.0 & 45.8 \\
\hline
\end{tabular}

Source: Latin American and Caribbean Demographic Centre (CELADE) - Population Division of ECLAC on the basis of special processing of census microdata. 



\section{Serie}

\section{E P \& L L población y desarrollo}

\section{Issues published}

78. Indigenous peoples and urban settlements: spatial distribution, internal migration and living conditions, Fabiana Del Popolo, Ana María Oyarce, Bruno Ribotta y Jorge Rodríguez (LC/L.2799-P), N de venta: E.07.II.G.132 (US\$ 10.00), 2007.

77. Desigualdades sociodemográficas en Nicaragua: tendencias, relevancia y políticas pertinentes, Maritza Delgadillo (LC/L.2794-P), N de venta: S.07.II.G.129 (US\$10.00), 2007.

76. Guía metodológica para la evaluación participativa de políticas y programas en el marco de la Estrategia Regional sobre el Envejecimiento, Sandra Huenchuan y Mariana Paredes (LC/L.2778-P), N de venta: S.07.II.G.112 (US\$ 10.00), 2007.

75. Estrategias para abogar en favor de las personas mayores, Alejandro Morlachetti, José Miguel Guzmán, Mónica Cuevas (LC/L.2739-P), N de venta: S.07.II.G.71 (US\$ 10.00), 2007.

74. Tugurios, migración y objetivos de desarrollo del Milenio, David Candia Baeza (LC/L.2654-P), N ${ }^{\circ}$ de venta: S.07.II.G.03 (US\$ 10.00), 2007.

73. Derechos humanos en población: indicadores para un sistema de monitoreo, Marcela Ferrer Lues (LC/L.2653-P), N ${ }^{\circ}$ de venta: S.07.II.G.05 (US\$ 10.00), 2007.

72. Patrones emergentes de la fecundidad y la salud reproductiva y sus vínculos con la pobreza en América Latina y el Caribe, Mariachiara Di Cesare (LC/L.2652-P), Nº de venta: S.07.II.G.04 (US\$ 10.00), 2007.

71. Vinculación de los emigrados latinoamericanos y caribeños con su país de origen: transnacionalismo y políticas públicas, Daniela Vono de Vilhena (LC/L.2645-P), N de venta: S.06.II.G.171 (US\$ 10.00), 2006.

70. Mecanismos participativos en el diseño, formulación e implementación de leyes, políticas y programas sobre envejecimiento, Mónica Villarreal Martínez (LC/L.2542-P), Nº de venta: S.06.II.G.70 (US\$ 10.00), 2006.

69. Familias, hogares, dinámica demográfica, vulnerabilidad y pobreza en Nicaragua, Milagros Barahona (LC/L.2523P), $\mathrm{N}^{\circ}$ de venta: S.06.II.G.50 (US\$ 10.00), 2006.

68. Análisis de percepciones y aportes para una política de migraciones internacionales en Nicaragua, José Luis Rocha Gómez (LC/L.2491-P), N de venta: S.06.II.G.27 (US\$ 10.00), 2006.

67. Migración internacional y desarrollo en Nicaragua, Eduardo Baumeister (LC/L.2488-P), $\mathrm{N}^{\circ}$ de venta: S.06.II.G.21 (US\$ 10.00), 2006.

66. Modelos demográficos para la proyección de la demanda del sector social, Timothy Miller (LC/L.2477-P), $\mathrm{N}^{\circ}$ de venta: S.06.II.G.10 (US\$ 10.00), 2006.

66. Demographic models for projections of social sector demand, Timothy Miller (LC/L.2477-P), Sales N: E.06.II.G.10, (US\$10.00), 2006.

65. La omisión censal en América Latina. 1950 - 2000, Odette Tacla Chamy (LC/L. 2475-P), $\mathrm{N}^{\circ}$ de venta: S.05.II.G.4 (US\$ 10.00), 2005.

64. La legislación a favor de las personas mayores en América Latina y el Caribe, Mónica Villarreal Martínez (LC/L.2468-P), Nº de venta: S.05.II.G.215 (US\$ 10.00), 2005.

63. Metas del milenio y tugurios: una metodología utilizando datos censales, David Candia Baeza (LC/L. 2456-P), $\mathrm{N}^{\circ}$ de venta: S.05.II.G.201 (US\$ 10.00), 2005.

62. Déficit habitacional en Brasil y México: estudio de dos megaciudades. Con base en los censos 1990-2000, Camilo Arriagada Luco (LC/L. 2433-P), Nº de venta: S.05.II.G.179 (US\$ 10.00), 2005.

61. Mujeres migrantes de América Latina y el Caribe: derechos humanos, mitos y duras realidades, Patricia Cortés Castellanos (LC/L.2426-P), Nº de venta: S.05.II.G.173 (US\$ 10.00), 2005.

60. La población y el desarrollo desde un enfoque de derechos humanos: intersecciones, perspectivas y orientaciones para una agenda regional, Marcela Ferrer (LC/L.2425-P), N de venta: S.05.II.G.172 (US\$ 10.00), 2005.

59. Propuesta para el análisis comparado de temas destacados de los derechos humanos de los afrodescendientes en América Latina, Marta Rangel (LC/L.2408-P), N de venta: S.05.II.G.155 (US\$ 10.00), 2005.

58. Dinámica demográfica y desarrollo en América Latina y el Caribe, CELADE (LC/L.2235-P), $\mathrm{N}^{\circ}$ de venta: S.04.II.G.155 (US\$ 10.00), 2005.

57. Unión y cohabitación en América Latina: ¿modernidad, exclusión, diversidad?, Jorge Rodríguez Vignoli (LC/L.2234-P), $\mathrm{N}^{\circ}$ de venta: S.04.II.G.154 (US\$ 10.00), 2005. 
56. Globalizados, pero restringidos. Una visión latinoamericana del mercado global de recursos humanos calificados, Jorge Martínez Pizarro (LC/L.2233-P), º de venta: S.04.II.G.153 (US\$ 10.00), 2005.

55. Commemoration of the tenth anniversary of the International Conference on Population and Development: actions undertaken to implement the programme of action of the Conference in Latin America and the Caribbean, Population Division (CELADE) (LC/L.2064/Rev.1-P), Nº de venta: E.04.II.G.78 (US\$ 10.00), 2004.

54. América Latina: los rostros de la pobreza y sus causas determinantes, Carlos Filgueira y Andrés Peri (LC/L.2149-P), $\mathrm{N}^{\circ}$ de venta: S.04.II.G.77 (US\$ 10.00), 2004.

53. América Latina y el Caribe: dinámica demográfica y políticas para aliviar la pobreza, Jorge Paz, José Miguel Guzmán, Jorge Martínez, Jorge Rodríguez (LC/L.2148-P), Nº de venta: S.04.II G.76 (US\$ 10.00), 2004.

52. La dinámica demográfica en América Latina, Juan Chackiel (LC/L.2127-P), $\mathrm{N}^{\mathrm{o}}$ de venta: S.04.II. G.55 (US\$10.00), 2004.

51. Marco legal y de políticas a favor de las personas mayores en América Latina, Sandra Huenchuan (LC/L. 2115-P), $\mathrm{N}^{\circ}$ de venta: S.04.II.G.44 (US\$ 10.00), 2004.

50. Migración interna en América Latina y el Caribe: estudio regional del período 1980-2000, Jorge Rodríguez Vignoli (LC/L.2059-P), N ${ }^{\circ}$ de venta: S.04.II.G.3 (US\$ 15.00), 2004.

49. El encanto de los datos. Sociodemografía de la inmigración en Chile según el censo de 2002, Jorge Martínez Pizarro (LC/L.2046-P), Nº de venta: S.03.II.G.208 (US\$ 10.00), 2003.

48. Estudio sobre la distribución espacial de la población en Colombia, Rocío Murad Rivera (LC/L.2013-P), N de venta: S.03.II.G.175 (US\$ 10.00), 2003.

47. Segregación residencial en áreas metropolitanas de América Latina: magnitud, características, evolución e implicaciones de política, Camilo Arriagada Luco y Jorge Rodríguez Vignoli (LC/L.1997-P), No de venta: S.03.II.G.159 (US\$ 10.00), 2003.

46. La fecundidad alta en América Latina y el Caribe: un riesgo en transición, Jorge Rodríguez Vignoli (LC/L.1996-P), $\mathrm{N}^{\mathrm{o}}$ de venta S.03.II.G.158 (US\$10.00), 2003.

45. América Latina: información y herramientas sociodemográficas para analizar y atender el déficit habitacional, Camilo Arriagada Luco (LC/L.1983-P), Nº de venta: S.03.II.G.142 (US\$ 10.00), 2003.

44. El mapa migratorio de América Latina y el Caribe, las mujeres y el género, Jorge Martínez Pizarro (LC/L.1974-P), $\mathrm{N}^{\mathrm{o}}$ de venta: S.03.II.G.133 (US\$ 10.00), 2003.

43. Determinantes próximos de la fecundidad. Una aplicación a países latinoamericanos, Guiomar Bay, Fabiana Del Popolo y Delicia Ferrando (LC/L.1953-P), Nº de venta: S.03.II.G.121 (US\$10.00), 2003.

42. América Latina: los sectores rezagados en la transición de la fecundidad,. Juan Chackiel y Susana Schkolnik (LC/L.1952-P), $\mathrm{N}^{\circ}$ de venta: S.03.II.G.120 (US\$10.00), 2003.

41. Autonomía o ciudadanía incompleta: el pueblo Mapuche en Chile y Argentina, Isabel Hernández (LC/L.1935-P), N de venta: S.03.II.G.94 (US\$ 10.00), 2003.

40. La reciente inmigración de latinoamericanos a España, Raquel Martínez Buján (LC/L.1922-P), $\mathrm{N}^{\circ}$ de venta: S.03.II.G.76 (US\$ 10.00), 2003.

- Readers wishing to obtain the above publications can do so by writing to the following address: ECLAC, Population Division, Casilla 179-D, Santiago, Chile, Fax (562) 2102069 , publications@cepal.org.

These publications are also available on the Internet: http://www.cepal.org/ o http://www.eclac.org

Name:

Activity:

Address:

Postal code, city, country:

Tel.:

Fax:

...mail address: 